Prepared in cooperation with the U.S. Army Corps of Engineers

\title{
The Shallow Stratigraphy and Sand Resources Offshore from Cat Island, Mississippi
}

By Jack L. Kindinger, Jennifer L. Miselis, and Noreen A. Buster

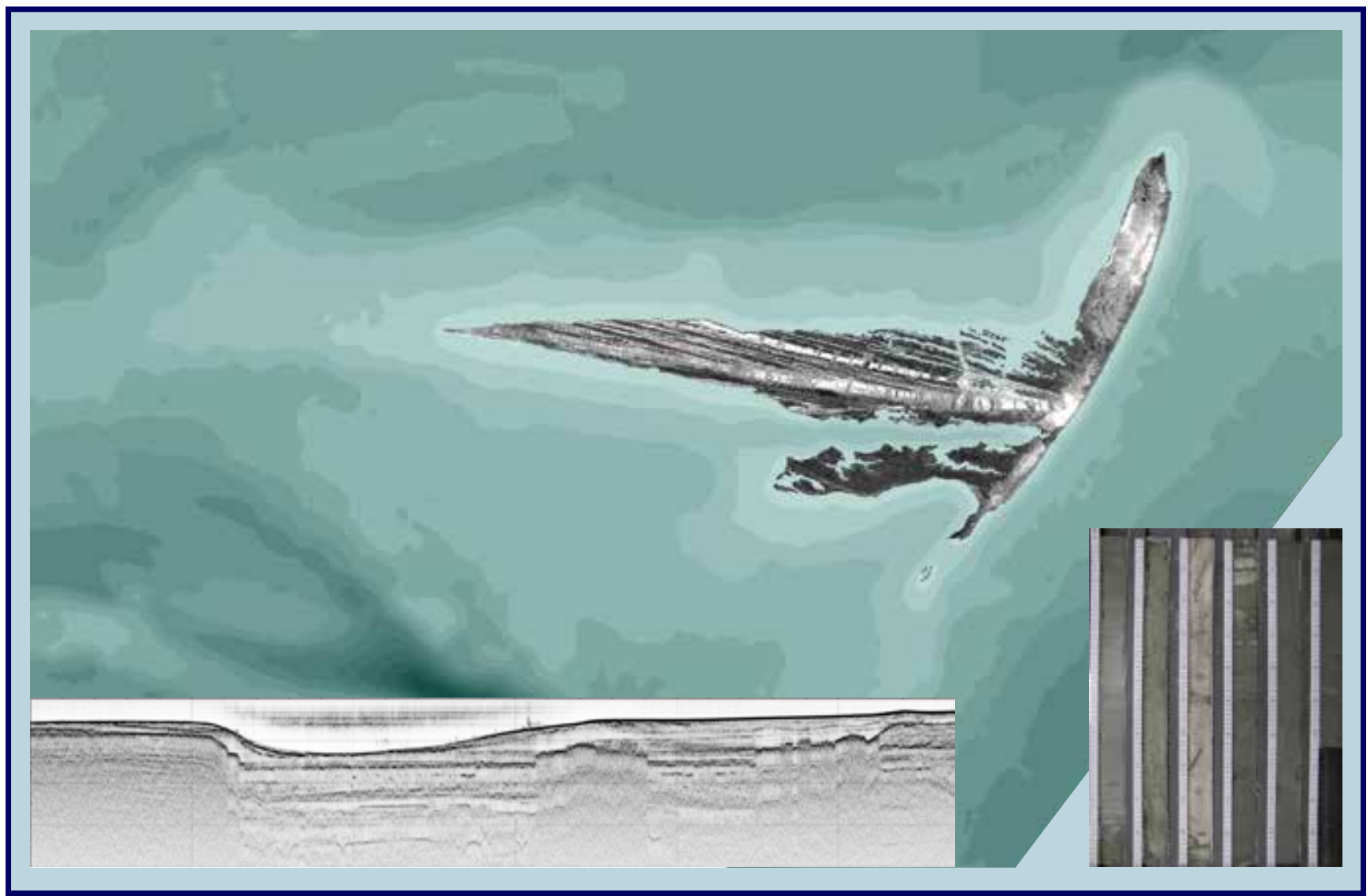

Open-File Report 2014-1070

U.S. Department of the Interior U.S. Geological Survey 


\section{U.S. Department of the Interior SALLY JEWELL, Secretary}

\section{U.S. Geological Survey \\ Suzette M. Kimball, Acting Director}

U.S. Geological Survey, Reston, Virginia: 2014

For more information on the USGS-the Federal source for science about the Earth, its natural and living resources, natural hazards, and the environment-visit http://www.usgs.gov or call 1-888-ASK-USGS

For an overview of USGS information products, including maps, imagery, and publications, visit $h$ ttp://www.usgs.gov/pubprod

To order this and other USGS information products, visit http://store.usgs.gov

Any use of trade, firm, or product names is for descriptive purposes only and does not imply endorsement by the U.S. Government.

Although this information product, for the most part, is in the public domain, it also may contain copyrighted materials as noted in the text. Permission to reproduce copyrighted items must be secured from the copyright owner.

Suggested citation:

Kindinger, J.L., Miselis, J.L., and Buster, N.A., 2014, The shallow stratigraphy and sand resources offshore from Cat Island, Mississippi: U.S. Geological Survey Open-File Report 2014 -1070, 74 p.

http://dx.doi.org/10.3133/ofr20141070. 


\section{Contents}

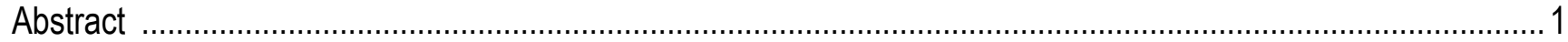

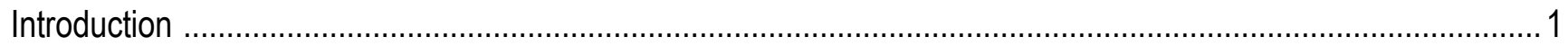

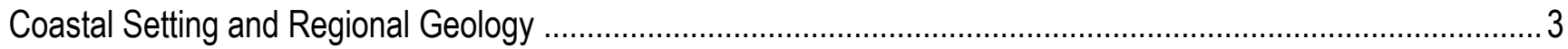

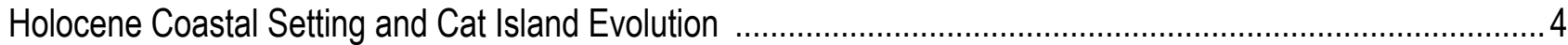

Cat Island Morphologic Changes since the Mid-1800s .............................................................................. 5

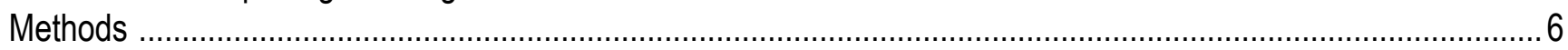

Geophysical-Data Collection and Processing: Bathymetry, Backscatter, and Seismic Reflection...................... 6

Sedimentary-Data Collection and Analysis ................................................................................... 10

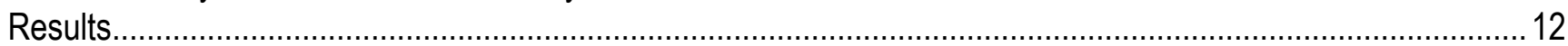

Geologic and Sedimentologic History North of Cat Island ...................................................................... 12

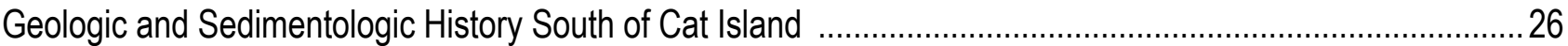

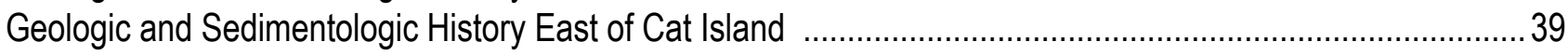

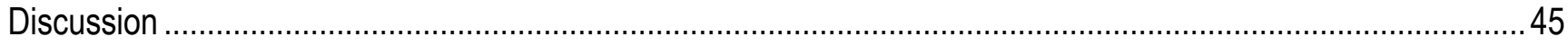

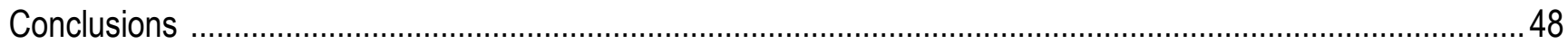

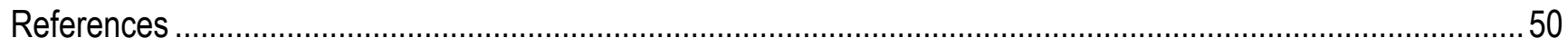

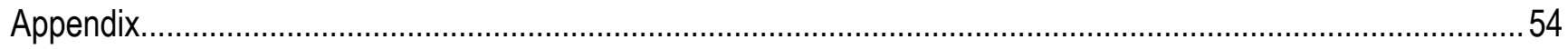




\section{Figures}

1. The northern Gulf of Mexico showing the Mississippi-Alabama barrier-island chain, from easternmost

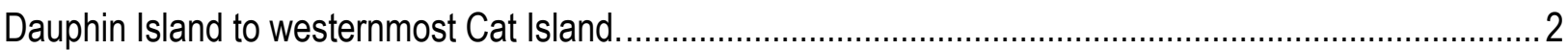

2. Shoreline change on Ship Island, east of Cat Island, from the mid-1800s to 2005 ....................................5

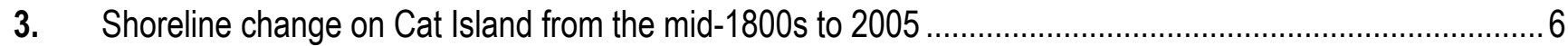

4. Photos of RV G.K. Gilbert mobilized with $(A)$ swath bathymetry equipment, $(B)$ a side-scan sonar towfish, and $(C)$ the chirp seismic towfish underway behind the RV G.K. Gilbert ................................................ 7

5. Geophysical tracklines for swath bathymetry and side-scan sonar and for single-beam bathymetry

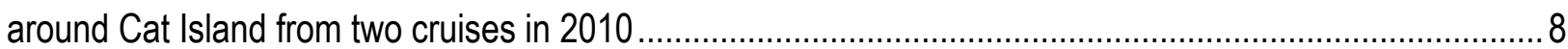

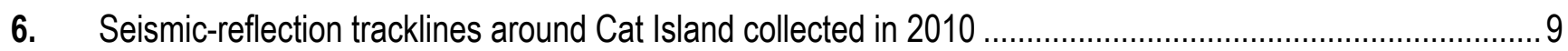

7. RV Streeterville mobilized with single-beam bathymetry equipment...................................................... 10

8. Location of marine vibracores and terrestrial vibracores collected from Cat Island and surrounding waters in 2010 overlain on a grid of the bathymetry...

9. Photos of $(A)$ marine vibracore collection aboard the RV G.K. Gilbert and $(B)$ terrestrial vibracore collection on Cat Island.

10. Detailed map of the bathymetry data collected around Cat Island showing the distinct morphology of each region.....

11. Map of the region north of Cat Island showing the location of seismic lines discussed in the report........... 15

12. Uninterpreted seismic profile 26 and $26 \mathrm{a}$ and the same profiles with interpretations ................................16

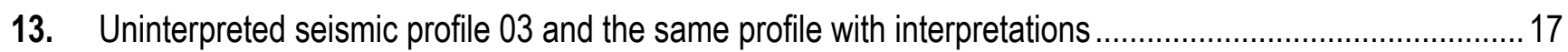

14. Uninterpreted seismic profile 13 from the northeast side of the Cat Island study area..............................17

15. Downcore analysis for marine vibracore 19 coupled with core photograph and seismic profile .................. 18

16. Maps showing $(A)$ the extent of the north lower sand unit and unit thickness and $(B)$ the depth to the top of the unit

17. Maps showing $(A)$ the extent of the north upper sand unit and unit thickness and $(B)$ the depth to the top of the unit.

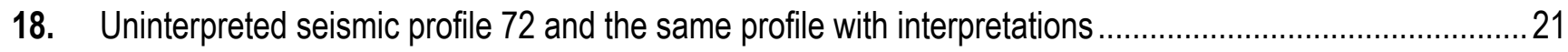

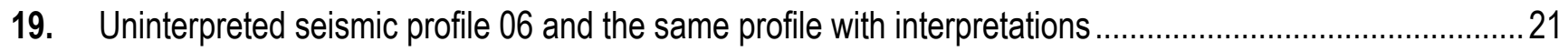

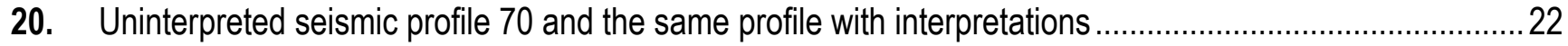

21. Downcore analysis for marine vibracore 07 coupled with core photograph and seismic profile ...................23

22. Uninterpreted seismic profiles 08 and 08 a and the same profiles with interpretations .................................24

23. Downcore analysis for marine vibracore 5 coupled with core photograph and seismic profile ....................25

24. Map of the region south of Cat Island showing the location of seismic lines discussed in the report ..........26

25. A non-interpreted and interpreted seismic-reflection profile from south of Cat Island shows all units

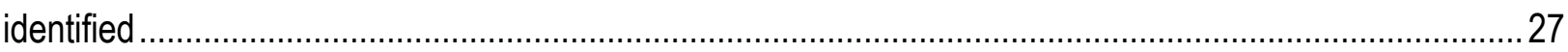

26. Downcore analysis for marine vibracore 28 coupled with core photograph and seismic profile ..................29

27. Downcore analysis for marine vibracore 13 coupled with core photograph and seismic profile 
28. Maps showing $(A)$ the extent of the southwest tidal delta unit and unit thickness and $(B)$ the depth to the top of the unit.

29. Downcore analysis for marine vibracore 15 coupled with core photograph and seismic profile...................32

30. Downcore analysis for marine vibracore 29 coupled with core photograph and seismic profile...................33

31. Maps showing $(A)$ the southern and eastern extent of the antecedent island platform unit and unit thickness and $(B)$ the depth to the top of the unit

32. Downcore analysis for marine vibracore $14 \mathrm{~B}$ coupled with core photograph and seismic profile .................36

33. Maps showing $(A)$ the extent of the southwest shoal unit and unit thickness and $(B)$ the depth to the top of the unit.

34. Map of acoustic backscatter from around Cat Island overlain with the grain size, in micrometers $(\mu \mathrm{m})$, of the surface sediment from all marine vibracores

35. Map of the region east of Cat Island showing the location of seismic lines discussed in the text or in figures 40

36. A non-interpreted and interpreted seismic-reflection profile from east of Cat Island that shows all units identified.

37. Downcore analysis for marine vibracore 3 coupled with core photograph and seismic profile

38. A comparison between a marine core collected east of Cat Island with a terrestrial core collected from the youngest beach-ridge complex

39. Comparison of the downcore analysis for core 8 and core 1 demonstrating the grain size and compositional similarities between deltaic sediments

40. Map of the sand units' extent identified in this study 46

41. Map depicting the interpreted extent of the antecedent island-platform unit north, south, and east of Cat Island.

42. Seismic profile 51 from south of Cat Island coupled with corresponding seismic profile 70 north of Cat Island.

\section{Tables}

1. Major sandy units identified around Cat Island, the vibracores in which they were sampled, their grain-size characteristics, and sedimentological composition

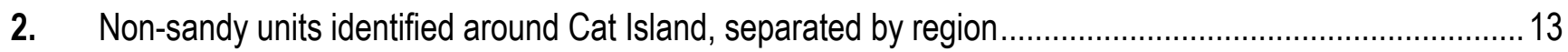

3. Lithology reference legend for all core description logs.

4. Areas, average thicknesses, and average depths to top for each of the sandy units identified in the study. 


\section{Appendix Figures}

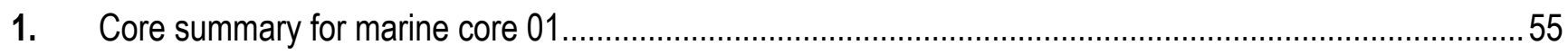

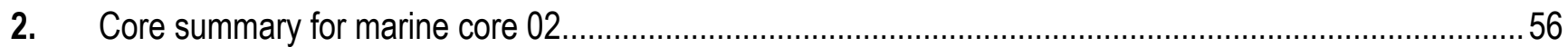

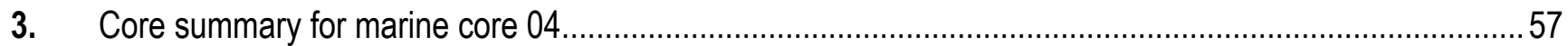

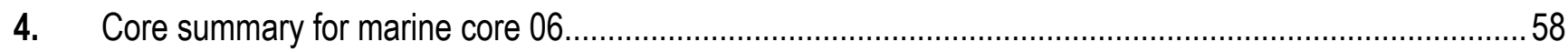

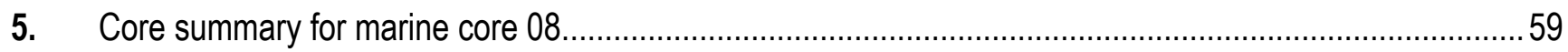

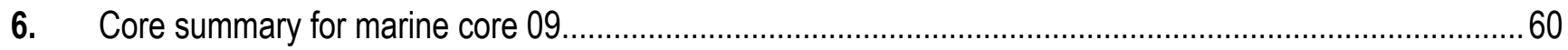

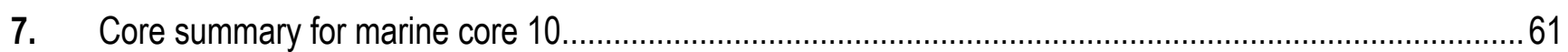

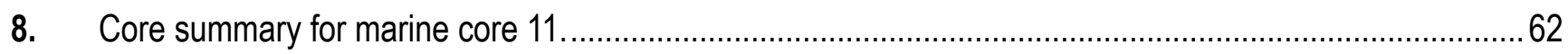

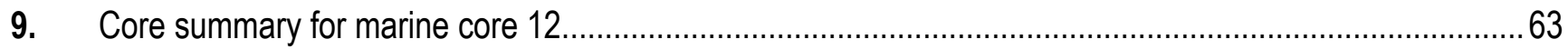

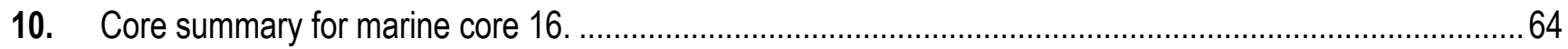

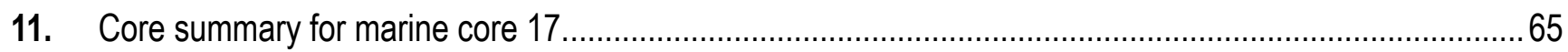

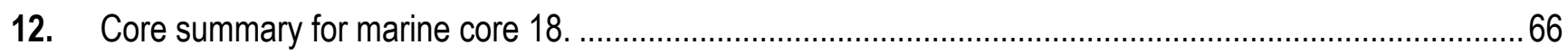

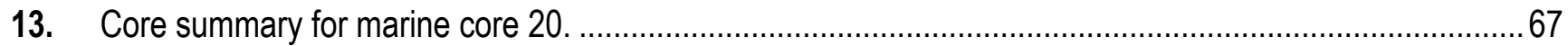

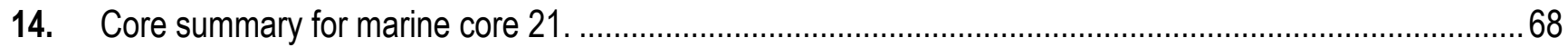

15. Core summary for marine core 22.

16. Core summary for marine core 23.

17. Core summary for marine core 24B.

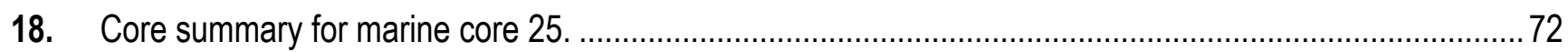

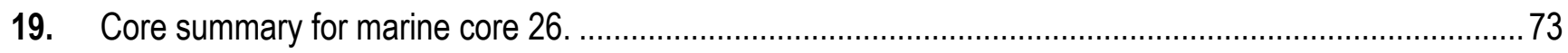

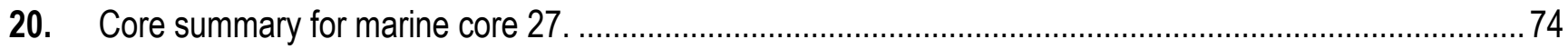




\section{Conversion Factors}

\begin{tabular}{|c|c|c|}
\hline Multiply & By & To obtain \\
\hline \multicolumn{3}{|c|}{ Length } \\
\hline inch (in.) & 2.54 & centimeter $(\mathrm{cm})$ \\
\hline inch (in.) & 25.4 & millimeter (mm) \\
\hline foot $(\mathrm{ft})$ & 0.3048 & meter $(\mathrm{m})$ \\
\hline mile (mi) & 1.609 & kilometer (km) \\
\hline mile, nautical (nmi) & 1.852 & kilometer $(\mathrm{km})$ \\
\hline yard (yd) & 0.9144 & meter $(\mathrm{m})$ \\
\hline \multicolumn{3}{|c|}{ Area } \\
\hline acre & 4,047 & square meter $\left(\mathrm{m}^{2}\right)$ \\
\hline acre & 0.4047 & hectare (ha) \\
\hline acre & 0.4047 & square hectometer $\left(\mathrm{hm}^{2}\right)$ \\
\hline acre & 0.004047 & square kilometer $\left(\mathrm{km}^{2}\right)$ \\
\hline square foot $\left(\mathrm{ft}^{2}\right)$ & 929.0 & square centimeter $\left(\mathrm{cm}^{2}\right)$ \\
\hline square foot $\left(\mathrm{ft}^{2}\right)$ & 0.09290 & square meter $\left(\mathrm{m}^{2}\right)$ \\
\hline square inch $\left(\right.$ in $\left.^{2}\right)$ & 6.452 & square centimeter $\left(\mathrm{cm}^{2}\right)$ \\
\hline section (640 acres or 1 square mile) & 259.0 & square hectometer $\left(\mathrm{hm}^{2}\right)$ \\
\hline square mile $\left(\mathrm{mi}^{2}\right)$ & 259.0 & hectare (ha) \\
\hline square mile $\left(\mathrm{mi}^{2}\right)$ & 2.590 & square kilometer $\left(\mathrm{km}^{2}\right)$ \\
\hline
\end{tabular}

Temperature in degrees Celsius $\left({ }^{\circ} \mathrm{C}\right)$ may be converted to degrees Fahrenheit $\left({ }^{\circ} \mathrm{F}\right)$ as follows:

$$
{ }^{\circ} \mathrm{F}=\left(1.8 \mathrm{x}^{\circ} \mathrm{C}\right)+32
$$

Temperature in degrees Fahrenheit $\left({ }^{\circ} \mathrm{F}\right)$ may be converted to degrees Celsius $\left({ }^{\circ} \mathrm{C}\right)$ as follows:

$$
{ }^{\circ} \mathrm{C}=\left({ }^{\circ} \mathrm{F}-32\right) / 1.8
$$




\section{Acknowledgments}

This study is part of the U.S. Army Corps of Engineers' Mississippi Coastal Improvements Program. We thank our cooperators, members of the U.S. Army Corps of Engineers, for the opportunity to work with them and continue our geologic assessment of the Mississippi-Alabama barrier-island chain. We especially acknowledge Dawn Lavoie for helping develop and organize this project. We thank Arnell Forde, Will Pfeiffer, and Kyle Kelso for data acquisition and processing. We also appreciate the field assistance and general support from the following people: James Flocks, Julie Bernier, Nancy DeWitt, Chandra Dreher, B.J. Reynolds, Dana Weise, Lance Thornton, Carl Taylor, Rich Young, and Dave Bennett (USGS), Dallon Weathers, Mike Brown, Kathryn Rose (University of New Orleans), Michael Potts (National Park Service), and Meghan Alesce (U.S. Army Corps of Engineers). We thank James Flocks and Barbara Lidz for their helpful and constructive reviews of this report. 


\title{
The Shallow Stratigraphy and Sand Resources Offshore from Cat Island, Mississippi
}

\author{
By Jack L. Kindinger, Jennifer L. Miselis, and Noreen A. Buster
}

\section{Abstract}

In collaboration with the U.S. Army Corps of Engineers, scientists from the U.S. Geological Survey (USGS) St. Petersburg Coastal and Marine Science Center collected over 487 line kilometers (>300 miles) of high-resolution geophysical data around Cat Island, Mississippi, to improve understanding of the island's geologic evolution and identify potential sand resources for coastal restoration. In addition, 40 vibracores were collected on and around the island, generating more than 350 samples for grain-size analysis.

The results indicate that the geologic evolution of Cat Island has been influenced by deltaic, lagoonal/estuarine, tidal, and oceanographic processes, resulting in a stratigraphic record that is quite complex. The region north of the island is dominated by lagoonal/estuarine deposition, whereas the region south of the island is dominated by deltaic and tidal deposition. In general, the veneer of modern sediment surrounding the island is composed of newly deposited sediment and highly reworked relict sediments. The region east of the island shows the interplay of antecedent barrier-island change with delta development despite a significant ravinement of sediments. The data show from little to no modern sediment east of the island, exposing relict sediments at the seafloor.

Finally, the data reveal four subaqueous sand units around the island. Two of the units are northwest of the modern island and one is southwest. Given the dominant, westward, longshore transport along the Mississippi and Alabama barrier islands, the geographic location of these three units suggests that they do not contribute to the modern sediment budget of Cat Island. The last unit is directly east of the island and represents the antecedent island platform that has supplied sand over geologic time for creation of the spits that form the eastern shoreline. Because of its location east of the island, the antecedent island unit may still supply sediment to the island today.

\section{Introduction}

Cat Island, the westernmost of the Mississippi-Alabama (MS-AL) barrier islands, is located 13 kilometers (km) (about 8.1 miles (mi)) from the Mississippi mainland (fig.1). The island is about $7.5 \mathrm{~km}$ (about $4.7 \mathrm{mi}$ ) long, east to west. Island width varies from a few meters at the west end to about $1.0 \mathrm{~km}$ (about $0.6 \mathrm{mi}$ ) mid-island. The north-south (N-S)-trending spit that forms the east beach of Cat Island is about $5 \mathrm{~km}$ (about $3.1 \mathrm{mi}$ ) long.

Despite its relatively small footprint (1773.2 acres (ac); 717.6 hectares (ha)), several stakeholders own the island. The National Park Service (NPS) purchased the west half and the southern-most tip of the island in 2002, and this property is now part of the Gulf Islands National Seashore. The east beach was purchased by BP Oil Company from the Boddie family in 2011 to expedite oil cleanup after the Deepwater Horizon oil spill. The remaining portions of Cat Island are privately owned. An agreement exists between the NPS and the private landowners to allow NPS to purchase most of the remaining part of the island in the future. Finally, part of Cat Island is a Mississippi Gulf Management Site (GEMS) with sensitive island habitats that include a subtidal estuarine habitat near shore with seagrass beds and 


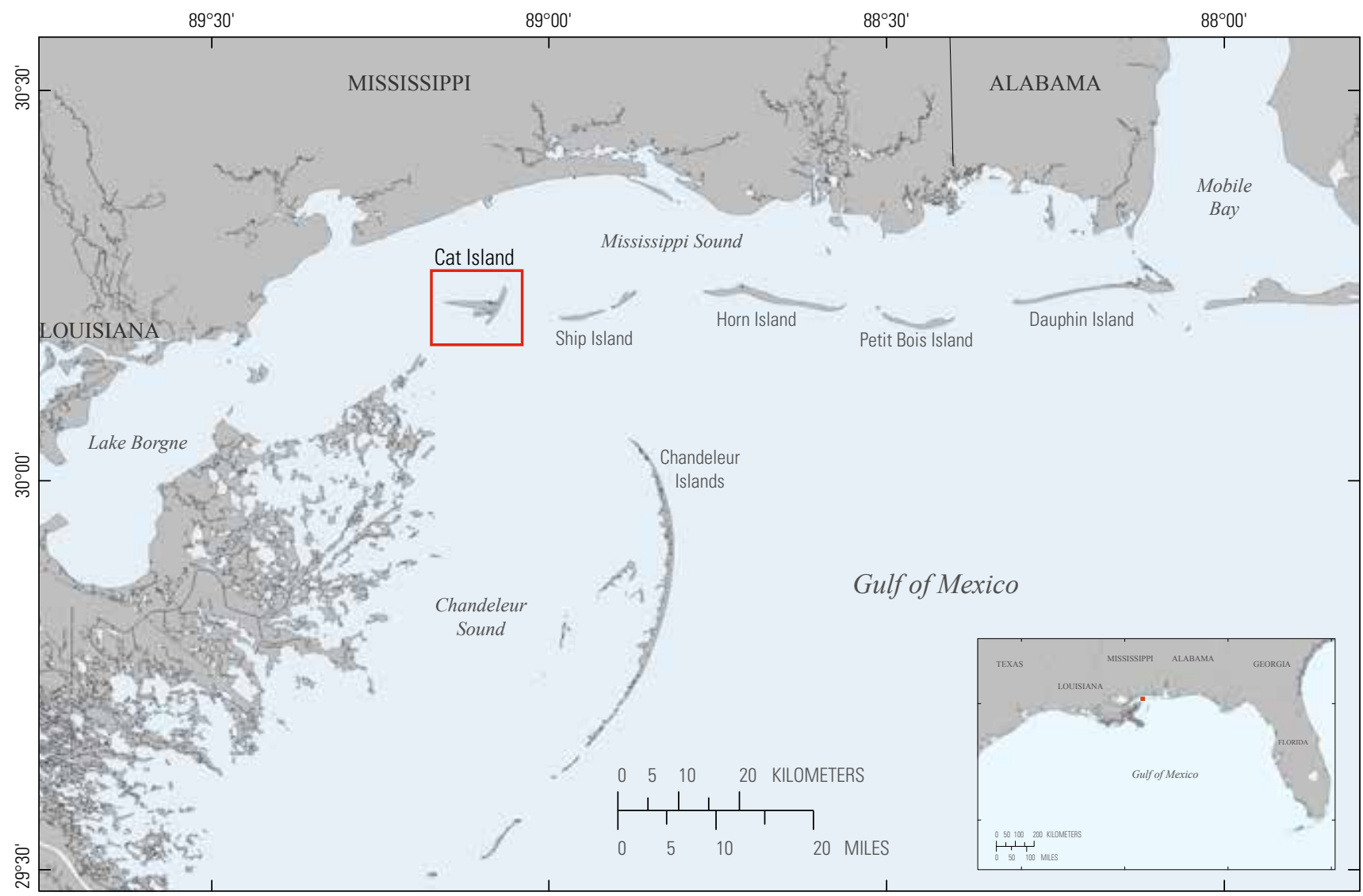

Figure 1. The northern Gulf of Mexico showing the Mississippi-Alabama (MS-AL) barrier-island chain, from easternmost Dauphin Island to westernmost Cat Island, which separates the Mississippi Sound from the Gulf of Mexico. The location of the study area is indicated by the red box.

mollusk reefs, and barrier-island pond/lagoon complexes with an inland, pine-oak, maritime woodland (http://www.dmr.state.ms.us/joomla16/index.php/mississippi-gems/209-cat-island). With so many stakeholders, the future management of the island and its natural resources will need to be based on sound science. Few studies have been done on the island itself or in the surrounding nearshore marine environments, so the purpose of this investigation was to provide a geomorphic study of the island. Because of the unique evolutionary history of the island, this investigation will also improve understanding of the geologic processes that contributed to the present coastal system.

The MS-AL barrier-island chain's geomorphology responds to physical processes (such as sealevel rise or storm-related wave energy) differently than other barrier islands around the Gulf of Mexico. The central Louisiana barrier islands have decreased in size or disappeared completely as they naturally transgressed landward (McBride and others, 1992; McBride and Byrnes, 1997), whereas the MS-AL barrier islands have naturally migrated westward but lost land over time due to anthropogenic causes resulting in decreased sand supply to the system (Morton, 2008). Only portions of the MS-AL barriers continue to migrate westward, eroding from the east end with deposition on the west end due to alongshore transport (Byrnes and others 2012; Walstra and others, 2012; Byrnes and others, 2013). However, dredged channels and ebb-tidal deltas have decreased the sediment supply to the islands, and for some islands the channels have ceased westward migration permanently, resulting in island land loss and narrowing (Morton, 2008). 
Even within the distinctive MS-AL geomorphologic regime, Cat Island itself is unique. The island currently has a characteristic " $\mathrm{T}$ " shape, which it did not always have; it was initially thought to be an east-west (E-W)-oriented linear island similar to other islands within the middle to late Holocene regressive barrier-island chain (Saucier, 1963; Frazier, 1967; Otvos, 1978, 1981). As the St. Bernard Delta Lobe (SBDL) of the Mississippi River encroached into the northern Gulf of Mexico around 4,000 years ago, the littoral-transport regime changed, and the east end of Cat Island began to erode into the N-Strending spit that exists today (Rucker and Snowden, 1989; Otvos and Giardino, 2004). Cat Island is also one of the more elevated barrier islands in the MS-AL chain. Rucker and Snowden (1989) reported that the northeast-southwest-trending spit has dune elevations of 2 to 3 meters $(\mathrm{m})$ (6.6 to 9.8 feet $(\mathrm{ft})$ ), and lidar data collected after Hurricane Katrina reveal an island maximum elevation of $\sim 4.5 \mathrm{~m}(15.1 \mathrm{ft})$ along the central relict beach ridges, which is higher than most MS-AL barrier islands (Smith and others, 2009; oral commun., Amar Nayegandhi, 2010). Finally, over historic time scales, the shorelines of Cat Island seemed to erode in place rather than translate to the west like the other barriers in the northern Gulf of Mexico (Morton, 2008).

Because of its complicated ownership status, few comprehensive geological studies have been conducted on Cat Island and its surrounding waters, despite a unique evolutionary history. Previous studies relied on rotary drill borings, vibracores, historic maps, and photographic data (Saucier, 1963; Frazier, 1967; Otvos, 1970, 1979, 1981, 1985, 1986; Knowles and Rosati, 1989; Rucker and Snowden, 1989; Byrnes and others, 1991; Morton, 2008), and none have focused on the island's subaqueous portion. The exception is the work of Rose (2010), which used a high-frequency chirp system to collect high-resolution geophysical profiles from around the island. The high-frequency system had difficulty penetrating the submerged strata, so many questions remained regarding the geologic history and geomorphic change that has occurred since its initial development.

This study builds on past efforts and combines shallow-water geophysical data with data from terrestrial and marine vibracores to provide an improved context for the geologic evolution of Cat Island. The objectives of this report are (1) to define the geologic and sedimentologic history of Cat Island and (2) identify potential subaqueous sand resources suitable for coastal-restoration projects, both planned and underway, in the northern Gulf of Mexico. We used physical descriptions and grain-size analyses from marine and terrestrial vibracores to characterize the sedimentologic history around the island and to interpolate the stratigraphy between core sites using over 487 line kilometers ( $>300$ line mi) of high-resolution chirp seismic data and high-frequency backscatter. Through the integration of sedimentologic and geophysical data, we identified stratigraphic units that may provide suitable sand resources and report their physical characteristics.

\section{Coastal Setting and Regional Geology}

Bordering the northern Gulf of Mexico, the 105-km (65-mi)-long MS-AL barrier chain is composed of Cat, west and east Ship, Horn, Petit Bois, and Dauphin islands (from west to east), including laterally interspersed, narrow shoal platforms and inlets. The barrier complex is backed by Mississippi Sound, a large lagoon/estuary that ranges in width from north to south approximately 4 to $20 \mathrm{~km}$ (about 2.5 to $12.5 \mathrm{mi}$ ), with water depths of 1 to $4 \mathrm{~m}$ (about 3.3 to $13.1 \mathrm{ft}$; fig. 1). Several rivers flow into Mississippi Sound (Pascagoula, Biloxi, Wolf, Jourdan, and Pearl) including the Mobile River, which discharges into Mobile Bay east of Dauphin Island. The Mobile River drains the fourth largest riverine basin in the U. S. (Isphording and others, 1989). 
Barrier-island formation and maintenance occur via the delivery and movement of sand by waves, tides, and currents. Oceanographic and coastal processes such as wind-driven waves and longshore currents are the driving forces for sediment movement along the northern Gulf Coast. Along the Mississippi coast, there are minimal seasonal differences in average significant wave heights and wave periods, which are about $0.6 \mathrm{~m}(\sim 2 \mathrm{ft})$ and 4 seconds $(\mathrm{s})$ respectively for winter months, and $0.4 \mathrm{~m}$ $(1.3 \mathrm{ft})$ and $3.5 \mathrm{~s}$ for summer months (Rosati and others, unpub. data, 2007). Sediment is mobilized by the predominant seasonal SE winds that drive alongshore currents to the west (Cipriani and Stone, 2001). These typical periods of relatively low wave energy are also punctuated by the passage of tropical storms, during which time wave heights and periods increase greatly due to significantly increased SE wind speed. The resulting strong currents produce substantial sediment transport from east to west (Morton, 1988; Walstra and others, 2012). These studies indicate that a single hurricane may transport the same amount of sediment as is transported by seasonal processes during a typical year.

Reduced sediment delivery from riverine systems and the dredging of navigation channels between the islands have disrupted the consistent flow of sand to the west, limiting the natural westward migration of the islands along the coast and increasing land loss. Continued land loss prompted the planning of restoration efforts to repair and maintain the barrier-island system because the barrier-island chain protects the mainland from tropical storm waves (Morton, 2008; Wamsley and others, 2013). As their name implies, barrier islands act as barriers to wave energy from low- to medium-sized storms. Larger, more intense storms, similar to Camille (1969) and Katrina (2005), overtop these low-lying islands and can extensively impact the island (Morton, 2008).

\section{Holocene Coastal Setting and Cat Island Evolution}

The MS-AL barrier islands formed within the last 4,500 years and are among the most dynamic, vulnerable and topographically low islands on the Gulf Coast (Otvos and Giardino, 2004). As sea level rose during the middle to late Holocene, a relict late Pleistocene beach ridge became the core around which eastern Dauphin Island developed, supplied by sand from the tidal delta associated with early Mobile Bay (Otvos and Giardino, 2004). The predominant SE-SSE wave approach generated westwarddirected net littoral drift along the new island. This process is thought to have formed a discontinuous, shallow and narrow sand platform on top of the muddy-sandy, nearshore marine deposits that previously lined the floor of the northern Gulf of Mexico basin (Otvos, 1985). Higher elevations eventually became emergent, forming the MS-AL barrier islands and isolating Mississippi Sound from the Gulf. It has been suggested that the western sector of the original barrier chain that included Cat Island extended well into southeastern Louisiana (the Pine Island Trend), which became inactive only a few centuries after its initiation around 4,000 to 3,800 years ago (Otvos and Giardino, 2004).

Strandplain growth ceased nearly 4,000 years ago, when the SBDL began to prograde into the northern Gulf of Mexico to the south of Cat, Ship, and Horn Islands (Frazier, 1967; Penland and others, 1985; Twichell and others, 2011). This delta lobe greatly reduced wave energy in western Mississippi Sound through extensive shoaling (see Otvos and Giardino, 2004, their fig. 17). This process likely diminished westward littoral sand transport, which, in turn, limited barrier growth west of Ship Island. Due to a limited sand supply to Cat Island from the east, reduced wave energy from the south resulting from growth of the SBDL, and redirected wave approach from the east-southeast, the sand eroded from the eastern strandplain margin was re-distributed by northward- and southwestward-directed littoral drift to form two spits on the eastern end of the island; growth of the spits created the characteristic shape of modern Cat Island (Rucker and Snowden, 1989; Otvos and Giardino, 2004). Using Morton's 1848 shoreline (Morton, 2008), Cat Island's estimated length was $\sim 9.5 \mathrm{~km}(\sim 5.9 \mathrm{mi})$; the width, including 
Middle Spit, was $\sim 2.0 \mathrm{~km}(\sim 1.2 \mathrm{mi})$; and the N-S spit length was $\sim 9.5 \mathrm{~km}(\sim 5.9 \mathrm{mi})$. As sediment supply to the delta was reduced through sporadic flow and eventual distributary abandonment, destructional processes began to affect the delta lobe (Penland and others, 1985). Tectonic and compactional subsidence reduced the elevation of the SBDL, leading to the retreat of delta-associated coastal marshlands and a configuration of barrier islands in the northern Gulf of Mexico similar to the one that exists today (Penland and others, 1985; Otvos and Giardino, 2004). Using USGS lidar data from 2007 (Smith and others, 2009), Cat Island's length was $\sim 7.9 \mathrm{~km}$ (4.9 mi); width was $\sim 1.8 \mathrm{~km}(1.1 \mathrm{mi})$; and the length of the N-S spit was $4.9 \mathrm{~km}(3.0 \mathrm{mi})$.

\section{Cat Island Morphologic Changes since the Mid-1800s}

Significant morphologic change to the MS-AL barrier islands has occurred since the mid-1800s (for specific rates of land loss see Morton, 2008). Ship Island, east of Cat Island (fig. 2), has experienced the most dramatic changes, including chronic breaching and significant shoreface erosion of the east and west segments of the island. Relative to other MS-AL barrier islands, the subaerial morphology of Cat Island has changed the least throughout its recent history (fig. 3). This is probably due to higher interior elevations and the orientation of the eastern shoreline of Cat Island, which prevents breaching and overwash by most storm waves except along the spits that form the eastern shoreline (Morton, 2008). The morphology of the N-S spit changed over time and is quite dynamic, demonstrating a clockwise rotation in its shoreline position. The central E-W portion of the island is less dynamic, but island perimeter loss has led to its narrowing over historic time scales (Morton, 2008). These changes resulted in 40 percent land loss between 1848 and 2007, and land loss rates increased over that time period, which included the passage of Hurricane Katrina and the post-storm recovery period (Morton, 2008).

Storms also influenced the morphology of Cat Island: Hurricane Katrina severed the southern portion of the N-S spit along the eastern shoreline, turning the southern spit into two small shoals (Otvos and Carter, 2008). The storm also breached the center of the N-S spit, isolating Middle Spit from the main portion of the island (Otvos and Carter, 2008). By early 2006, the isolated barrier-spit segments were reemerging, reintegrating and expanding (Morton, 2008). It is likely that these processes continue today, but it is unclear whether or not Cat Island will reassume its pre-Katrina footprint.

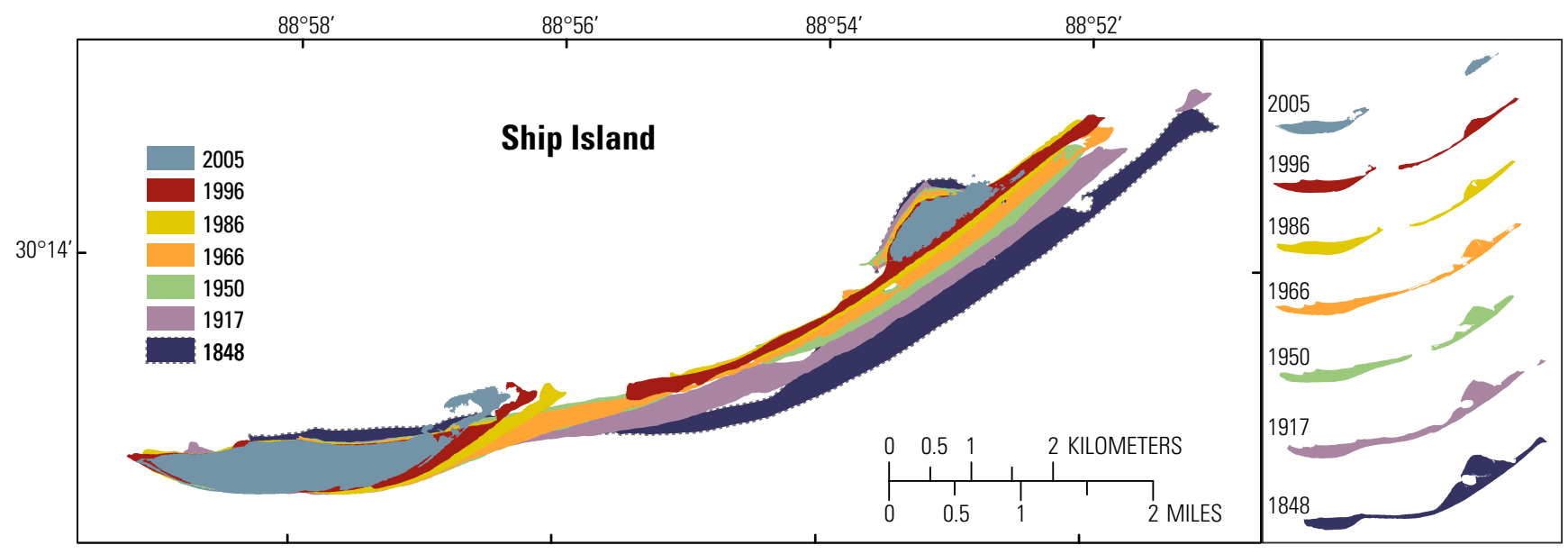

Figure 2. Shoreline change on Ship Island, east of Cat Island, from the mid-1800s to 2005 (modified from Morton, 2008). 


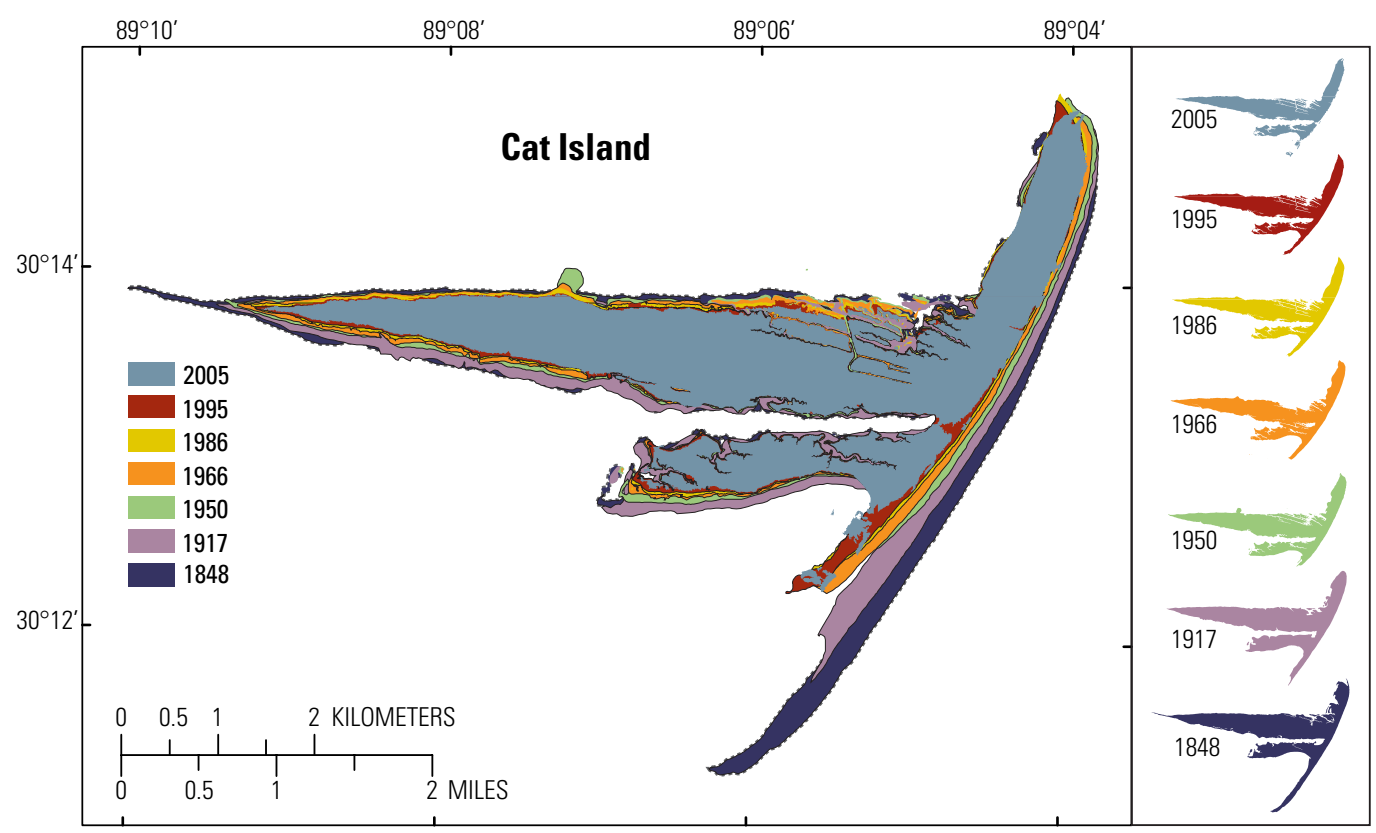

Figure 3. Shoreline change on Cat Island from the mid-1800s to 2005. In comparison to Ship Island, Cat Island has remained relatively stable (modified from Morton, 2008).

\section{Methods}

Data in this report were acquired during multiple field activities. The geophysical data - bathymetry, backscatter, and seismic reflection-were collected during two cruises as part of the Barrier-Island Monitoring (BIM) project (USGS Field Activity Numbers 10BIM04 and 10BIM05). Eleven terrestrial vibracores were collected between August 4 and 6, 2010, and 29 marine vibracores were collected between October 20 and 22, 2010, aboard the USGS research vessel (RV) G.K. Gilbert as part of the BIM project (USGS Field Activity Numbers 10BIM03 and 10BIM06, respectively). The geophysical and sedimentologic data obtained during these cruises were published in three USGS Data Series reports: (1) bathymetry and backscatter (Buster and others, 2012), (2) seismic reflection (Forde and others, 2012), and (3) sedimentologic data (Buster and others, 2014). These publications contain detailed information about data processing and analysis techniques and metadata for each data type. Data-processing methods will only be summarized here. Readers are encouraged to seek out the above publications for more detailed information.

\section{Geophysical-Data Collection and Processing: Bathymetry, Backscatter, and Seismic Reflection}

The USGS conducted the first Cat Island geophysical cruise from September 7 to 15, 2010, aboard the 50-ft RV G.K. Gilbert (Buster and others, 2012). Four-hundred eighty-seven line km (>300 line-mi) of data were acquired using an integrated suite of geophysical instruments. Seafloor morphology was mapped using a 468-kilohertz (kHz) SEA (Systems Engineering and Assessment, Ltd.) SWATHplus-H interferometric sonar and a Coda Octopus F190R Precision Attitude and Positioning System, with depth measurements corrected for vessel motion in real time (fig. $4 A$ ). Speed of sound was measured at sonar transducer depth and from water-column profiles collected intermittently throughout each survey day to reduce depth errors associated with speed-of-sound changes in the water column. The seafloor texture was mapped with acoustic-backscatter data derived from a dual-frequency Klein 
3900 side-scan sonar towfish (fig. 4B). Sub-seafloor stratigraphy was mapped using an EdgeTech SB$512 \mathrm{i}$ Chirp towfish towed from a pontoon sled $\sim 1 \mathrm{~m}$ below the water's surface (fig. $4 \mathrm{C}$ ). Data were acquired using a frequency sweep of $1-10 \mathrm{kHz}$ and $0.5-8 \mathrm{kHz}$, a $43-\mathrm{kHz}$ sample frequency, and a record length of 75 milliseconds (ms). Position data were integrated into all systems using navigation information supplied by an OmniSTAR HP (high-precision) differential global navigation satellite system. Survey tracklines (76 line segments) were shore-parallel with a spacing of approximately $300 \mathrm{~m}$, with crossing lines collected perpendicular and oblique to shore-parallel lines (fig. 5). The total survey area was $\sim 100 \mathrm{~km}^{2}\left(38.6 \mathrm{mi}^{2}\right)$ with 22 percent coverage of the seafloor. Seafloor elevation ranged from -0.49 to $-12.85 \mathrm{~m}(-1.6$ to $-42.2 \mathrm{ft})$ NAVD88.

SWATHplus-H served as the acquisition software and the initial processing software for interferometric bathymetry data from the first cruise. Roll-calibration data were collected and processed using SWATHplus-H and Grid Processor 3.7.10 (both products of Systems Engineering and Assessment Ltd.) (Buster and others, 2012). Processed-data files were written from this software and incorporated roll-calibration values, equipment offsets, acquisition parameters, navigation and motion, and speed of sound. Calibration and filtering conducted in SWATHplus was also saved to the processed-data files, which were imported into CARIS HIPS and SIPS, version 7.1, where the soundings were edited for outliers. The acquisition datum for OmniSTAR HP position and navigation was the International Terrestrial Reference Frame (ITRF2005), and data were processed to the reference ellipsoid World Geodetic System 84 (WGS84). The bathymetry was exported as an ASCII text file from a CARIS base surface that was gridded with a $10 \mathrm{~m}$ cell size.

Side-scan-sonar (backscatter) data were imported into CARIS SIPS version 7.1.1. In CARIS, navigation and attitude data were examined and corrected (Buster and others, 2012). After corrections
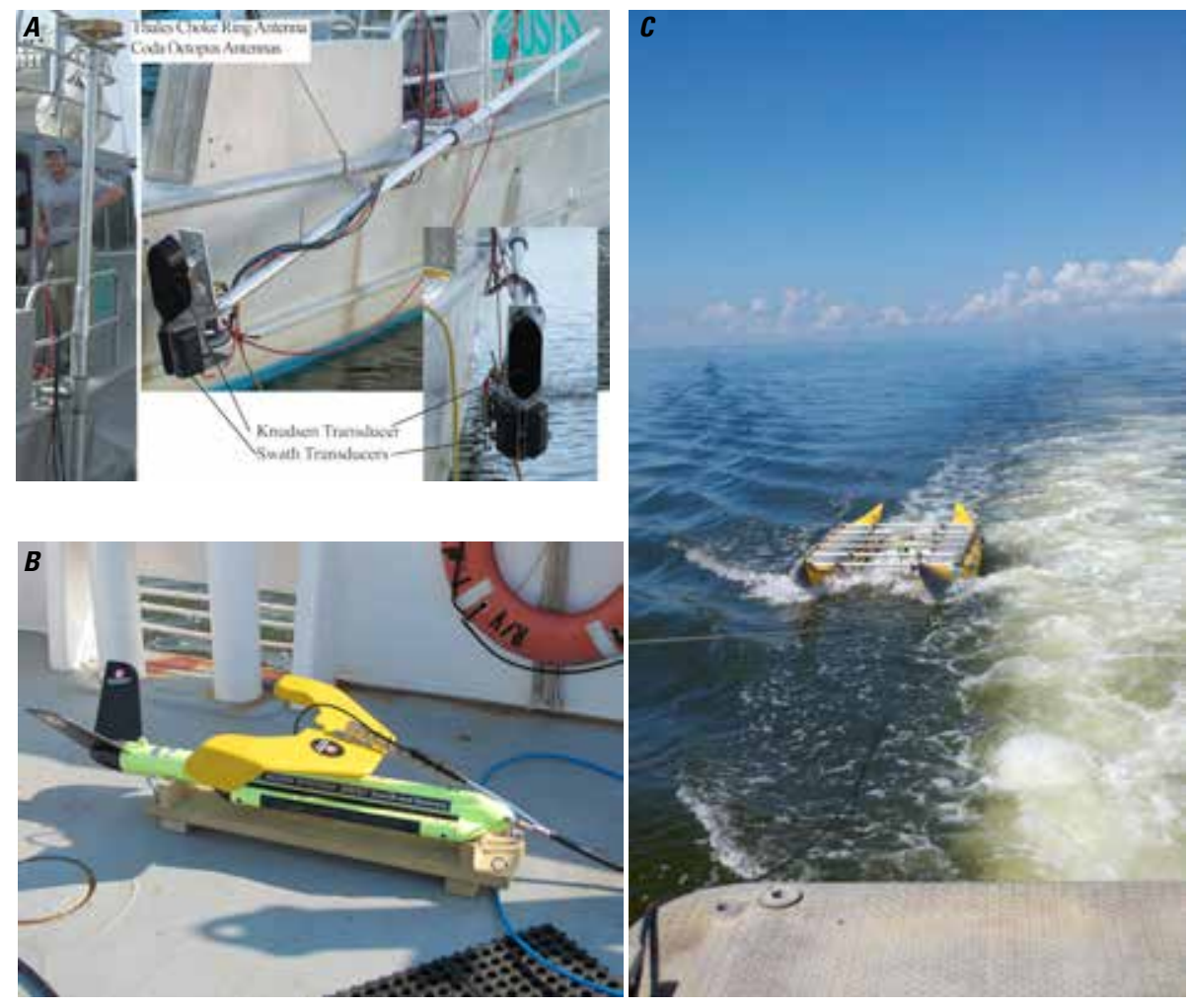

Figure 4. Photos of RV G.K. Gilbert mobilized with $(A)$ swath bathymetry equipment, $(B)$ a sidescan sonar towfish, and $(C)$ the chirp seismic towfish underway behind the RV G.K. Gilbert. 
were made, the tracklines were converted to CARIS Georeferenced Backscatter Rasters (GeoBars), and a full mosaic was created to a common intensity histogram and exported in GeoTIFF format. In general, low backscatter values (dark colors) have weak acoustic reflections and are finer grained material such as muds and fine sands, whereas light colors have strong reflections and indicate coarser material on the seafloor.

Seismic-reflection data were collected along the tracklines shown in figure 6 and were saved in a standard SEG-Y data format (the standard Society of Exploration Geophysicists (SEG) format (Barry and others, 1975)) during acquisition. These data were processed with Seismic Unix (SU) to produce gain-controlled GIF images of the sub-bottom profiles included in this report. The chirp data-processing sequence consisted of (1) removing navigation data from each shot and converting the shot to SU format, (2) applying automatic gain control, (3) generating a PostScript image of the traces, and (4) converting the PostScript image to a GIF image. Shot-point navigation, start-of-line, and 1,000-shot-interval

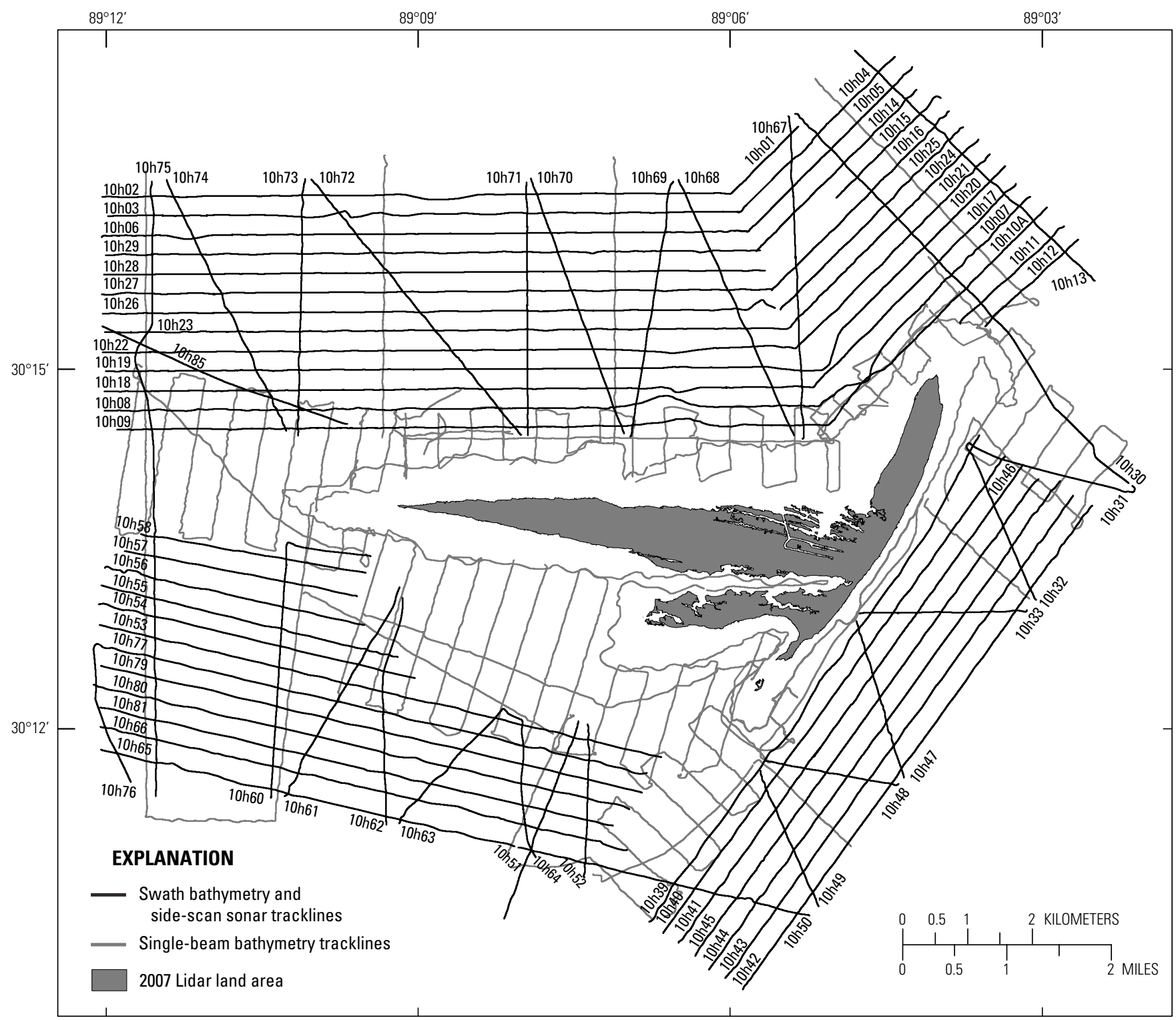

Figure 5. Geophysical tracklines for swath bathymetry and side-scan sonar (black) and for single-beam bathymetry (gray) around Cat Island from two cruises in 2010. 


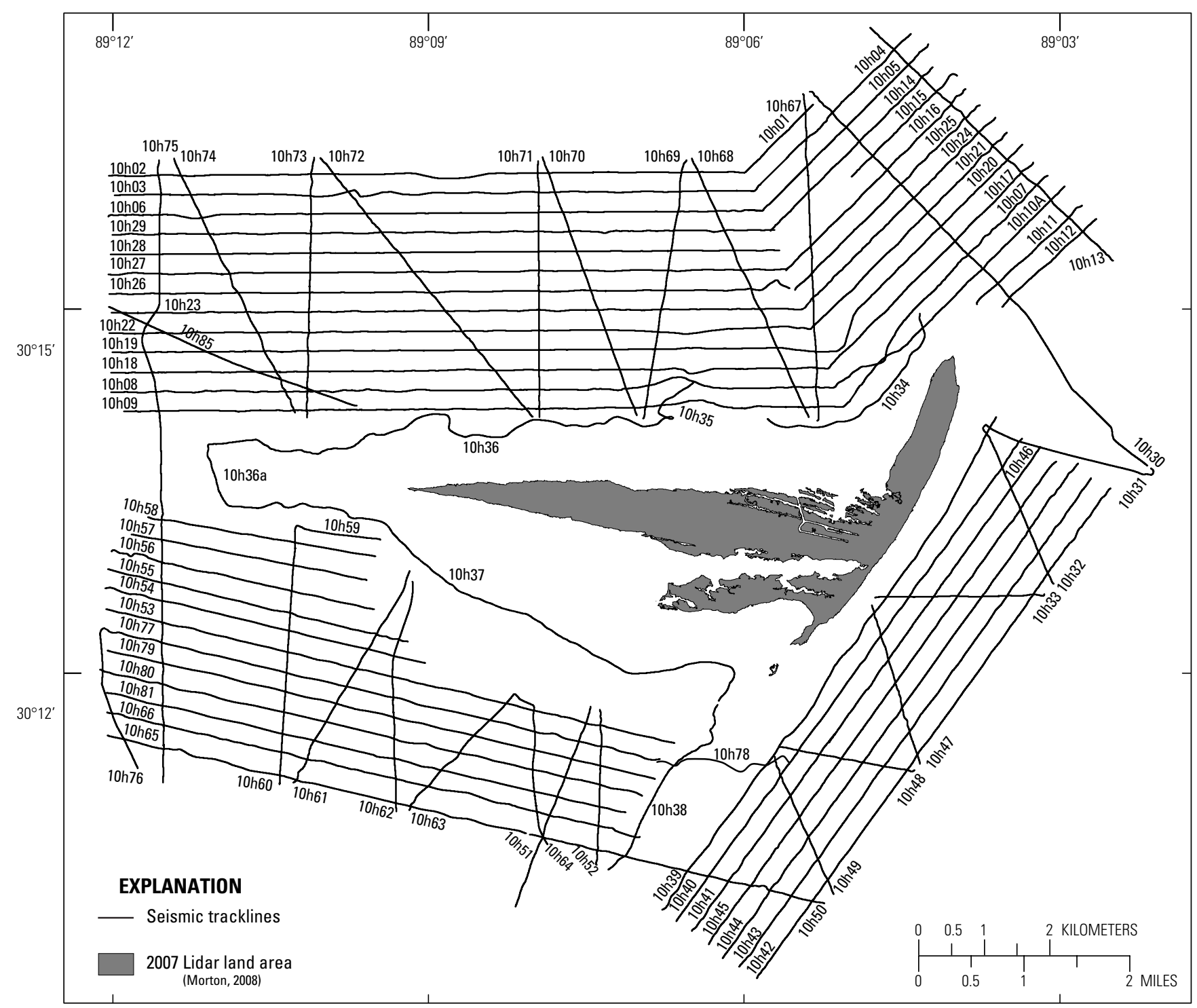

Figure 6. Seismic-reflection tracklines around Cat Island collected in 2010.

location files were extracted using SU software and output as ASCII text files; they were then processed with PROJ.4.7.0 (http://trac.osgeo.org/proj/) to generate Universal Transverse Mercator (UTM) coordinates (WGS84, Zone 16, meters) from latitude and longitude coordinates. The archived seismic data can be viewed and downloaded from Forde and others (2012).

Processed seismic data were imported into OpendTect, an open-source, seismic-interpretation software system (http://www.opendtect.org/). Seismic data were adjusted so that the seafloor reflection from the seismic profile matched the seafloor elevation measured with the interferometric sonar. Spatially continuous seismic stratigraphic horizons identified were digitized for each adjusted seismic profile, making each horizon's elevation relative to the NAVD88 vertical datum. Volumetric calculations were performed by exporting triangulated, three-dimensional grids of each unit's bounding horizons. The area, volume, and average thickness (isopach) between the upper and lower boundary for each unit of interest were calculated using a custom script in open-source Generic Mapping Tools (GMT). 
A second cruise was conducted from September 28 to October 2, 2010 aboard the 22-ft USGS research vessel RV Streeterville; 274 line $\mathrm{km}(\sim 170$ line mi) of single-beam bathymetry data were collected on the cruise (Buster and others, 2012). Survey tracklines (106 line segments) were primarily perpendicular to shore with a spacing of approximately $500 \mathrm{~m}$ (1640 ft, fig. 5). Differentially corrected navigation data were collected with a global positioning system (GPS) base station assembled at the pre-existing National Geodetic Survey (NGS) Benchmark BH08 at Point Cadet Marina in Biloxi, Mississippi. Depth soundings were recorded at $50 \mathrm{~ms}$ intervals with a Marimatech E-SEA-103 echosounder system with dual 208-kHz transducers (fig. 7). The single-beam bathymetry was acquired using HYPACK version 10 (HYPACK, Inc.).

Data processing for the second cruise began with the post-processing of navigation data to ensure the most accurate position for each single-beam sounding. Base-station GPS data were corrected using the time-weighted average National Geodetic Survey On-Line Positioning User Service (OPUS) solution coordinates, and the sounding positions were adjusted to the final base-station value (WGS84 (1150) datum) (Buster and others, 2012). Corrected positions were parsed into CARIS HIPS and SIPS, version 7.1, and merged with imported bathymetric soundings. The final processed soundings were exported from CARIS as ASCII text files.

To create a complete bathymetric grid for the survey area, single-beam and interferometric soundings were integrated. The text files generated by each processing sequence were merged within Esri ArcGIS version 10.0.2. To prevent the grid from generating errant values at the shallow extent of the data, bathymetry data were merged with Experimental Advanced Airborne Research Lidar (EAARL) elevation data collected from Cat Island by the USGS in 2007 (Smith and others, 2009) and a $50 \mathrm{~m}$ $(164 \mathrm{ft})$ cell grid was created for publication. The archived bathymetry and backscatter data can be viewed and downloaded from Buster and others (2012).

\section{Sedimentary-Data Collection and Analysis}

Twenty-nine marine vibracores were collected from the RV G.K. Gilbert (figs. 8 and 9) (Buster and others, 2014). For each core site, the core number, location, local water depth, and recovered core length, as well as other relevant information, were recorded. The vibracores were transported to the Core-Analysis Laboratory at the USGS St. Petersburg Coastal and Marine Science Center (SPCMSC). Each vibracore was cut into $1 \mathrm{~m}(3.28 \mathrm{ft})$ sections and split lengthwise. One-half of each core was described with standard sediment-logging methods, photographed, and wrapped in plastic sleeves for archival storage. The other core half was sampled at $2-3 \mathrm{~cm}(0.79-1.18$ in) intervals at the top, middle, and bottom of each described sediment unit for grain-size analysis. Grain-size analyses on 367 coresediment samples were performed using a Coulter LS 200 particle-size analyzer (https://www.beckmancoulter.com/). Raw grain-size data were then imported into GRADISTAT, a free, widely available program that calculates the geometric (in metric units) and logarithmic (in phi units, $\Phi$; Krumbein, 1934) mean, mode, sorting, and skewness for

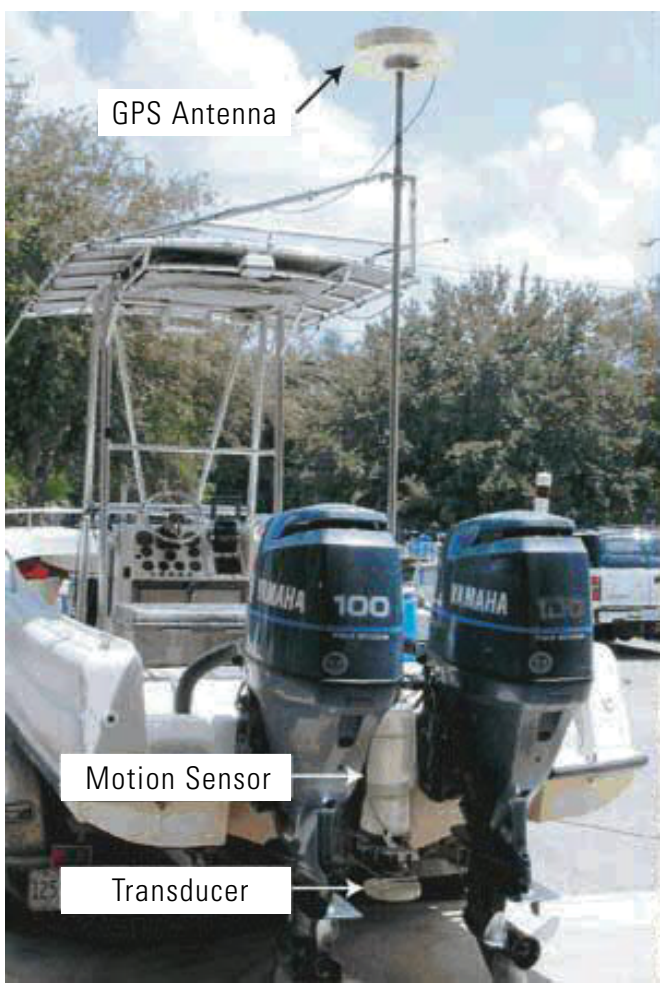

Figure 7. RV Streeterville mobilized with singlebeam bathymetry equipment. 


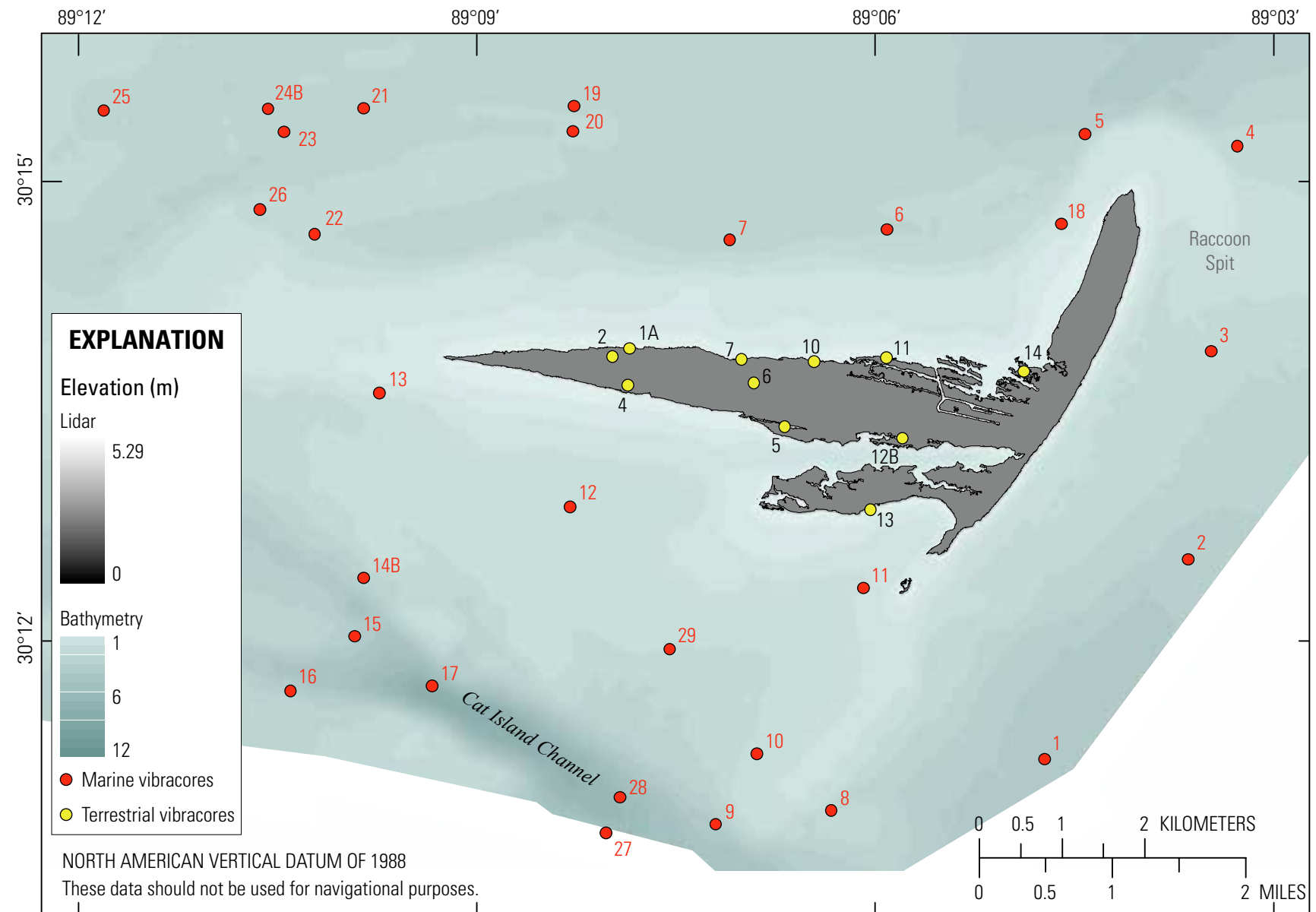

Figure 8. Location of marine vibracores (red) and terrestrial vibracores (yellow) collected from Cat Island and surrounding waters in 2010 overlain on a grid of the bathymetry. Note the location of Cat Island Channel south of the island and Raccoon Spit on the north end of the eastern shoreline.

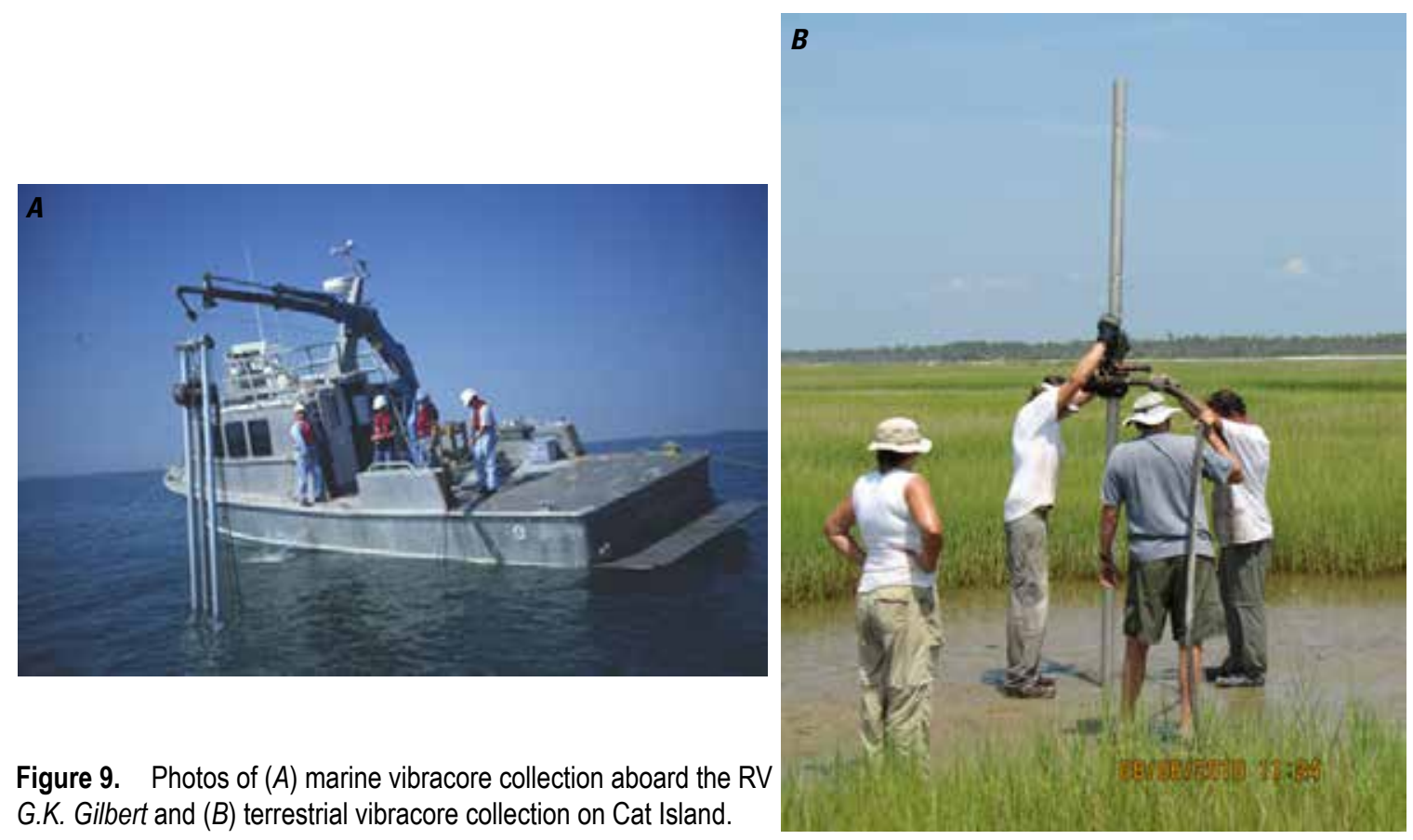


each sample using the Folk and Ward (1957) method (Blott and Pye, 2001; http://www.kpal.co.uk/gradistat.html). GRADISTAT also calculates the fraction of sediment from each sample by size category (for example, clay, coarse silt, or fine sand) based on a modified Wentworth (1922) size scale. A Visual Basic macro script developed by the USGS was applied to calculate the average and standard deviation for each sample set (6 runs per sample) and remove runs that varied from the set average by more than \pm 1.5 standard deviations. The sample average was recalculated using the remaining runs.

In addition to the marine vibracores, 11 terrestrial vibracores were collected from Cat Island. Because the focus of this report is on subaqueous sand resources, the terrestrial data are not discussed, although a description of the terrestrial coring methods and data-analysis techniques is reviewed in Buster and others (2014).

\section{Results}

Throughout its geologic history, deltaic, tidal, estuarine, and oceanographic processes influenced Cat Island and its surrounding nearshore environments, leaving a stratigraphic record that is complex. To facilitate interpretation, analysis, and presentation of the results, the subaqueous environments are divided into three regions: north, south, and east (fig. 10). The geologic and sedimentologic history of each region is described in the sections below. The lithologic characteristics of sandy units identified are shown in table 1; characteristics for all other units are shown in table 2; the lithologic symbol legend is shown in table 3.

\section{Geologic and Sedimentologic History North of Cat Island}

The north side of Cat Island is bound to the south by the main portion of the island and extends $5.0 \mathrm{~km}$ (3.11 mi) north into Mississippi Sound, including a 2-km-long (1.24 mi-long) section on the

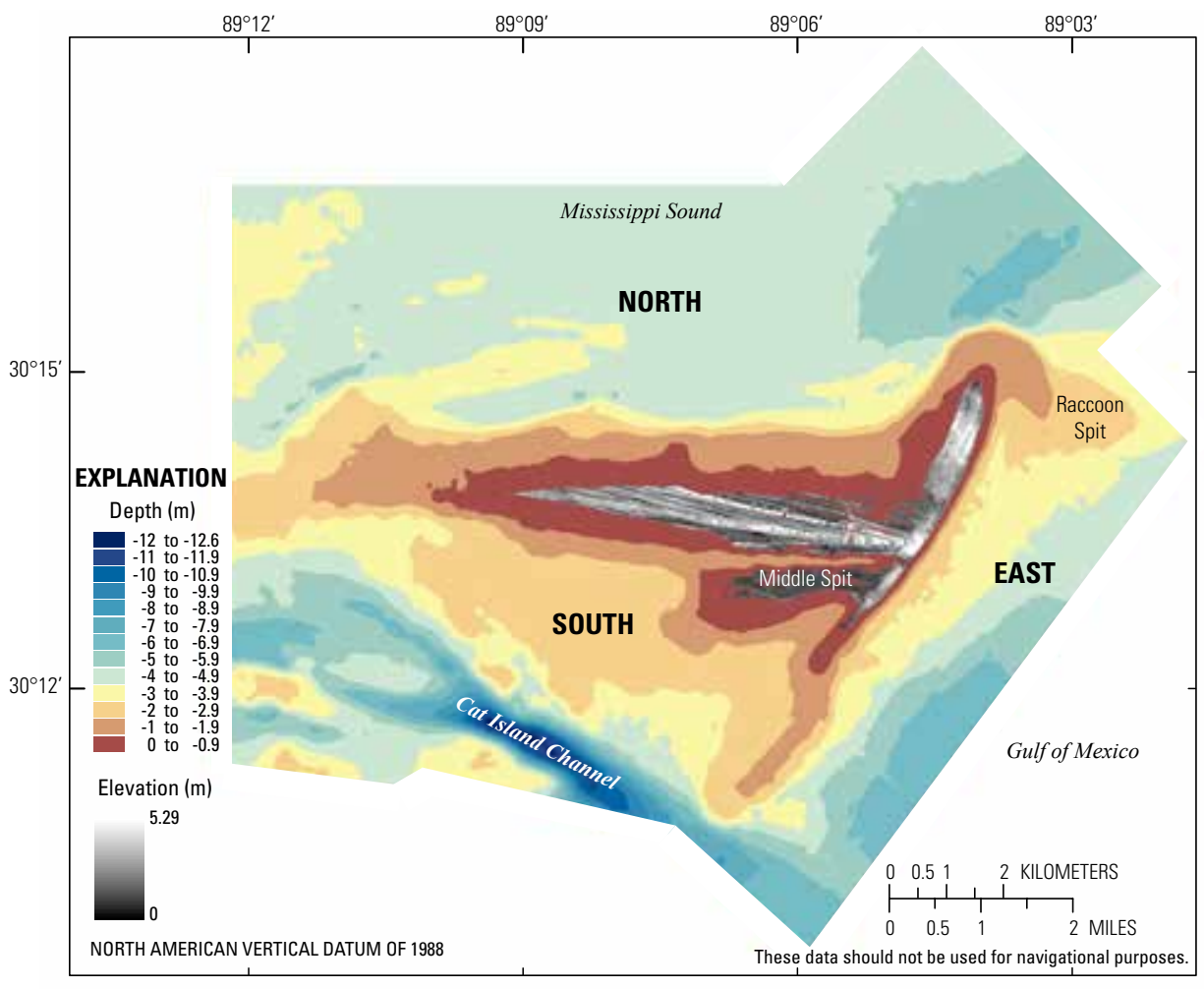

Figure 10. Detailed map of the bathymetry data collected around Cat Island showing the distinct morphology of each region (north, south, east) discussed in the text. Note that the southern shoreface is more gradual in slope than that to the north or east (topographic lidar modified from Smith and others, 2009). 
Table 1. Major sandy units (and their abbreviations) identified around Cat Island, the vibracores in which they were sampled, their grain-size characteristics, and sedimentological composition. All values are averages of the GRADISTAT output for each sample taken from all cores associated with the unit.

[Measurements are in micrometers $(\mu \mathrm{m})$.]

\begin{tabular}{|c|c|c|c|c|c|c|c|}
\hline MAIN SANDY UNITS & $\begin{array}{l}\text { CORES WITH } \\
\text { UNITS }\end{array}$ & $\begin{array}{c}\text { MEAN } \\
\text { GRAIN SIZE } \\
(\mu \mathrm{m})\end{array}$ & $\begin{array}{l}\text { STANDARD } \\
\text { DEVIATION } \\
(\mu \mathrm{m})\end{array}$ & $\begin{array}{l}\text { MEAN GRAIN-SIZE } \\
\text { RANGE }\end{array}$ & $\begin{array}{c}\mathrm{D}_{10}, \mathrm{D}_{50}, \mathrm{D}_{90} \\
(\mu \mathrm{m})\end{array}$ & $\begin{array}{l}\text { SAND } \\
(\%)\end{array}$ & $\begin{array}{c}\text { MUD } \\
(\%)\end{array}$ \\
\hline SOUTH ANTECEDENT ISLAND PLATFORM (AIP) & $11,12,13,29$ & 319.8 & 4.5 & Fine Sand - Medium Sand & $166.2,319.0,581.8$ & 96.6 & 3.4 \\
\hline SOUTHWEST SHOAL (SWS) & $14 \mathrm{~B}$ & 322.5 & 2.8 & Medium Sand & $196.4,319.4,513.7$ & 97.9 & 2.1 \\
\hline$\because \therefore$ SOUTHWEST TIDAL DELTA (SWTD) & 13 & 203.6 & 2.6 & Fine Sand & $112.1,202.2,378.5$ & 95.2 & 4.8 \\
\hline$\because \because$ NORTH UPPER SAND (NUS) & $19-21,23,24 \mathrm{~B}$ & 242.3 & 5.8 & Fine Sand - Medium Sand & $107.4,244.9,462.0$ & 92.9 & 7.2 \\
\hline$\because \because$ NORTH LOWER SAND (NLS) & $19-21,23,25$ & 249.2 & 2.6 & Fine Sand - Medium Sand & $149.9,243.3,460.1$ & 97.5 & 2.5 \\
\hline$\because \vdots$ EAST ANTECEDENT ISLAND PLATFORM (AIP) & 3 & 271.9 & 8.3 & Fine Sand - Medium Sand & $139.6,271.5,512.7$ & 95.6 & 4.4 \\
\hline
\end{tabular}

Table 2. Non-sandy units (and their abbreviations) identified around Cat Island, separated by region. Columns include the vibracores in which the unit was sampled, its grain-size characteristics, and sedimentological composition. All values are averages of the GRADISTAT output for each sample taken from all cores associated with the unit.

[Measurements are in micrometers $(\mu \mathrm{m})$.]

\begin{tabular}{|c|c|c|c|c|c|c|c|c|c|}
\hline OTHER UNITS (SOUTH AND EAST) & $\begin{array}{l}\text { CORES WITH } \\
\text { UNITS }\end{array}$ & $\begin{array}{c}\text { MEAN } \\
\text { GRAIN SIZE } \\
(\mu \mathrm{m})\end{array}$ & $\begin{array}{l}\text { STANDARD } \\
\text { DEVIATION } \\
(\mu \mathrm{m})\end{array}$ & $\begin{array}{l}\text { MEAN GRAIN SIZE } \\
\text { RANGE }\end{array}$ & $\begin{array}{c}D_{10}, D_{50}, D_{90} \\
(\mu \mathrm{m})\end{array}$ & $\begin{array}{l}\text { SAND } \\
(\%)\end{array}$ & $\begin{array}{c}\text { MUD } \\
(\%)\end{array}$ & $\begin{array}{c}\text { CLAY } \\
(\%)\end{array}$ & $\begin{array}{l}\text { SILT } \\
(\%)\end{array}$ \\
\hline$\because$ MODERN 1 (M1) & $2,9,11,13,14,16,17,27,28$ & 46.0 & 4.4 & Medium Silt - Very Fine Sand & $2.9,84.8,291.8$ & 42.6 & 57.4 & 8.5 & 48.9 \\
\hline$\therefore \because$ MODERN 2 (M2) & $11,12,15-17,27,29$ & 122.8 & 9.5 & Very Coarse Silt - Medium Sand & $31.6,158.4,370.6$ & 65.7 & 34.3 & 5.2 & 29.1 \\
\hline -- MODERN 3 (M3) & 9,14 & 6.5 & 0.1 & Very Fine Silt - Coarse Silt & $1.3,7.0,39.4$ & 6.6 & 93.4 & 22.9 & 70.6 \\
\hline$=\exists$ MODERN 4 (M4) & 11,12 & 7.6 & 0.8 & Very Fine Silt - Medium Silt & $1.3,5.4,119.3$ & 11.1 & 88.9 & 22.1 & 66.8 \\
\hline$\because \therefore$ MODERN 5 (M5) & 12,15 & 355.9 & 7.5 & Medium Sand & $136.1,367.6,611.4$ & 92.4 & 7.6 & 1.3 & 6.3 \\
\hline$=$ ST. BERNARD 2 - SOUTH (SB2) & $9,10,14 B, 15-17,27,28$ & 14.2 & 1.6 & Very Fine Silt - Very Coarse Silt & $1.6,18.8,123.5$ & 15.9 & 84.1 & 17.3 & 66.8 \\
\hline$=$ ST. BERNARD 2 - EAST (SB2) & $1,2,8$ & 19.0 & 1.0 & Fine Silt - Coarse Silt & $1.9,24.7,157.4$ & 27.2 & 72.9 & 12.0 & 60.9 \\
\hline ST. BERNARD 1 - SOUTH (SB1) & $9,10,14 B, 15-17,27,28$ & 14.5 & 0.7 & Very Fine Silt - Very Coarse Silt & $1.6,15.2,91.3$ & 14.4 & 85.6 & 16.3 & 69.3 \\
\hline ST. BERNARD 1 - EAST (SB1) & $1,2,8$ & 7.6 & 0.1 & Very Fine Silt - Medium Silt & $1.4,8.5,41.8$ & 6.1 & 93.9 & 19.5 & 74.4 \\
\hline$\ldots . . .$. TRANSITIONAL DELTA TO SHOAL (TDS) & $14 \mathrm{~B}$ & 94.3 & 0.9 & Medium Silt - Medium Sand & $48.3,98.6,270.5$ & 46.9 & 53.1 & 7.6 & 45.5 \\
\hline$\cdots$ TRANSITIONAL SHELF TO DELTA (TSD) & $14 \mathrm{~B}, 28$ & 60.9 & 1.2 & Coarse Silt - Very Fine Sand & 3.6, 116.6, 306.5 & 58.5 & 41.5 & 6.6 & 34.9 \\
\hline TRANSITIONAL SHELF TO DELTA (TSD) & 28 & 215.2 & 2.7 & Fine Sand & $119.2,212.7,405.3$ & 96.0 & 4.0 & 1.0 & 3.0 \\
\hline$\therefore \therefore$ INNER-SHELF PLATFORM (ISP) & 17,18 & 235.4 & 9.8 & Fine to Medium Sand & $85.0,259.5,493.6$ & 90.5 & 9.5 & 2.0 & 7.5 \\
\hline \multicolumn{10}{|l|}{ OTHER UNITS (NORTH) } \\
\hline$\because-\because$ LAGOONAL 1 (L1) & $5-7,19-26$ & 70.7 & 2.9 & Medium Silt - Fine Sand & $12.0,100.8,256.2$ & 48.4 & 51.6 & 7.7 & 43.9 \\
\hline$\Rightarrow$ LAGOONAL 2 (L2) & $5,6,20,25,26$ & 56.3 & 3.9 & Medium Silt - Fine Sand & $3.2,108.7,299.7$ & 52.2 & 47.8 & 8.4 & 39.4 \\
\hline$=-$ LAGOONAL $3(\mathrm{~L} 3)$ & 22 & 5.6 & 0.1 & Fine Silt & $1.3,5.2,29.9$ & 3.7 & 96.3 & 20.8 & 75.6 \\
\hline LAG...... LAGONAL 4 (L4) & 22,26 & 11.2 & 0.6 & Fine Silt - Coarse Silt & $1.4,8.3,141.6$ & 16.6 & 83.4 & 18.7 & 64.7 \\
\hline$=-7$ LAGOONAL 5 (L5) & 5 & 5.2 & 0.1 & Fine Silt & $1.1,4.2,44.9$ & 5.7 & 94.3 & 24.6 & 69.7 \\
\hline$=$ LAGOONAL 6 (L6) & $5-7,19-24 B, 26$ & 18.6 & 1.0 & Fine Silt - Very Fine Sand & $1.7,30.0,159.1$ & 23.7 & 76.3 & 15.1 & 61.2 \\
\hline$\because \therefore$ ISLAND PLATFORM 1 (IP1) & 6,7 & 207.3 & 11.5 & Fine to Medium Sand & $48.6,232.1,389.0$ & 87.4 & 12.6 & 2.8 & 9.8 \\
\hline F....... ISLAND PLATFORM 2 (IP2) & 6 & 70.9 & 5.4 & Coarse Silt - Very Fine Sand & $4.5,141.0,313.5$ & 56.8 & 43.2 & 5.7 & 37.5 \\
\hline ….... TRANSITIONAL ISLAND PLATFORM (TIP) & 7 & 113.9 & 8.3 & Very Fine to Fine Sand & 8.6, 193.2, 321.4 & 77.1 & 22.9 & 4.1 & 18.8 \\
\hline
\end{tabular}


Table 3. Lithology reference legend for all core description logs.

\begin{tabular}{|c|c|c|c|c|c|}
\hline \multicolumn{6}{|c|}{ EXPLANATION OF SYMBOLS USED IN CORE LOG DESCRIPTIONS } \\
\hline & \multicolumn{2}{|l|}{ Lithology } & \multicolumn{2}{|l|}{ Bedding and Deformation } & \multirow{2}{*}{$\begin{array}{l}\text { Physical Characteristics } \\
\text { Root mat }\end{array}$} \\
\hline : & Sand & $\Xi \Xi 三$ & Massive & $\lambda_{\lambda}$ & \\
\hline$\therefore$ & Muddy Sand & $\equiv$ & Laminated & y & Root pieces \\
\hline$F$ & Silty or Sandy Clay or Mud & $\approx$ & Mottled & 魚 & Woody fragment \\
\hline$E=-1$ & Clay or Mud & 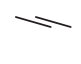 & Inclined contact/bedding & $n$ & Shell fragments \\
\hline$\ldots \ldots$ & Sand and Clay or Mud & $\approx$ & Deformed contact/bedding: concave-up & ๑ & Large shell fragment \\
\hline 72 & (2) & $\approx$ & Deformed contact/bedding: concave-down & 9 & Burrow fill \\
\hline & & $\approx$ & Deformed contact/bedding: wavy or irregular & & \\
\hline Me & cores $\phi$ Grain-size analy & iple dep & Grain-size analysis sam & $(\mathrm{on} \mathrm{pl}$ & noto) \\
\hline
\end{tabular}

backside of the northern part of the N-S spit (fig. 11). High-resolution seismic profiles and vibracores were interpreted to reconstruct the geologic history of Cat Island's north side, and only a limited amount of data can be shown in this report. Data relevant to the interpretations presented have been published as USGS Data Series reports (see Methods section for references). In this section, the characteristics of the seismic-stratigraphy units, their structure, and inter-unit relationships are discussed.

The Pleistocene-Holocene erosional unconformity is the basal seismic horizon identified in this study and is found across much of the study area (fig. 12). The Pleistocene-Holocene erosional unconformity formed as the relative sea-level rise flooded the region, leaving a recognizable but discontinuous erosional ravinement surface. The ravinement horizon is distinct in that it usually caps infilled paleofluvial and paleotidal channels incised into the coastal plain during the last glacial maximum (sea-level lowstand). Below what we interpret as the ravinement, several large, incised valleys, that may have been cut by the ancestral Pearl River (fig. 13), were identified. The ravinement dips from northeast to southwest from a depth below sea level (bsl) of 10-14 m (38-46 ft) in the northeast and 10-21 m (38-69 ft) in the southwest (fig. 14).

Using seismic profiles in combination with grain-size analysis, vibracore descriptions and photographs, inner-shelf platform (ISP), north lower sand (NLS), and north upper sand (NUS) units were differentiated from the northwest area of Cat Island (figs. 12 and 15). ISP is thickest to the southern side of Cat Island and thins to pinch out on the northern portion of the study area. The ISP is composed of marine, muddy sand with clay-filled burrows and abundant shell hash. Overlying the ISP unit are the NLS and NUS units. Both units are located in close proximity to, and onlap, a submerged remnant of the Cat Island antecedent platform at the southern extent of the survey lines (see the description below), and both the NLS and NUS units extend outside the study area at the northern extent of the study area (figs. 16 and 17). The NLS can be identified in seismic profiles by its steep clinoforms that appear to dip north (fig. 18). The NLS extends beyond the study area to the west and thins to the east where it eventually pinches out (fig. 16). The NLS covers an area of $22.81 \mathrm{~km}^{2}\left(8.49 \mathrm{mi}^{2}\right)$ with an average thickness of $3.17 \mathrm{~m}(10.4 \mathrm{ft})$, ranging from 0.09 to $8.59 \mathrm{~m}(0.3$ to $28.2 \mathrm{ft})$ (table 4$)$. Average overburden is $4.26 \mathrm{~m}$ $(14.0 \mathrm{ft})$ with a range of 1.22 to $9.68 \mathrm{~m}(4.0$ to $31.8 \mathrm{ft})$ (table 4$)$. Sediment volume for the NLS unit is estimated at 72 million cubic meters $\left(\mathrm{M} \mathrm{m}^{3} ; 94.17 \mathrm{M} \mathrm{yd}^{3}\right)$ (table 4). The unit was penetrated by cores 19, $20,21,23$, and 24B. Grain-size analysis indicates that it is composed of greater than 90 percent fine- to 


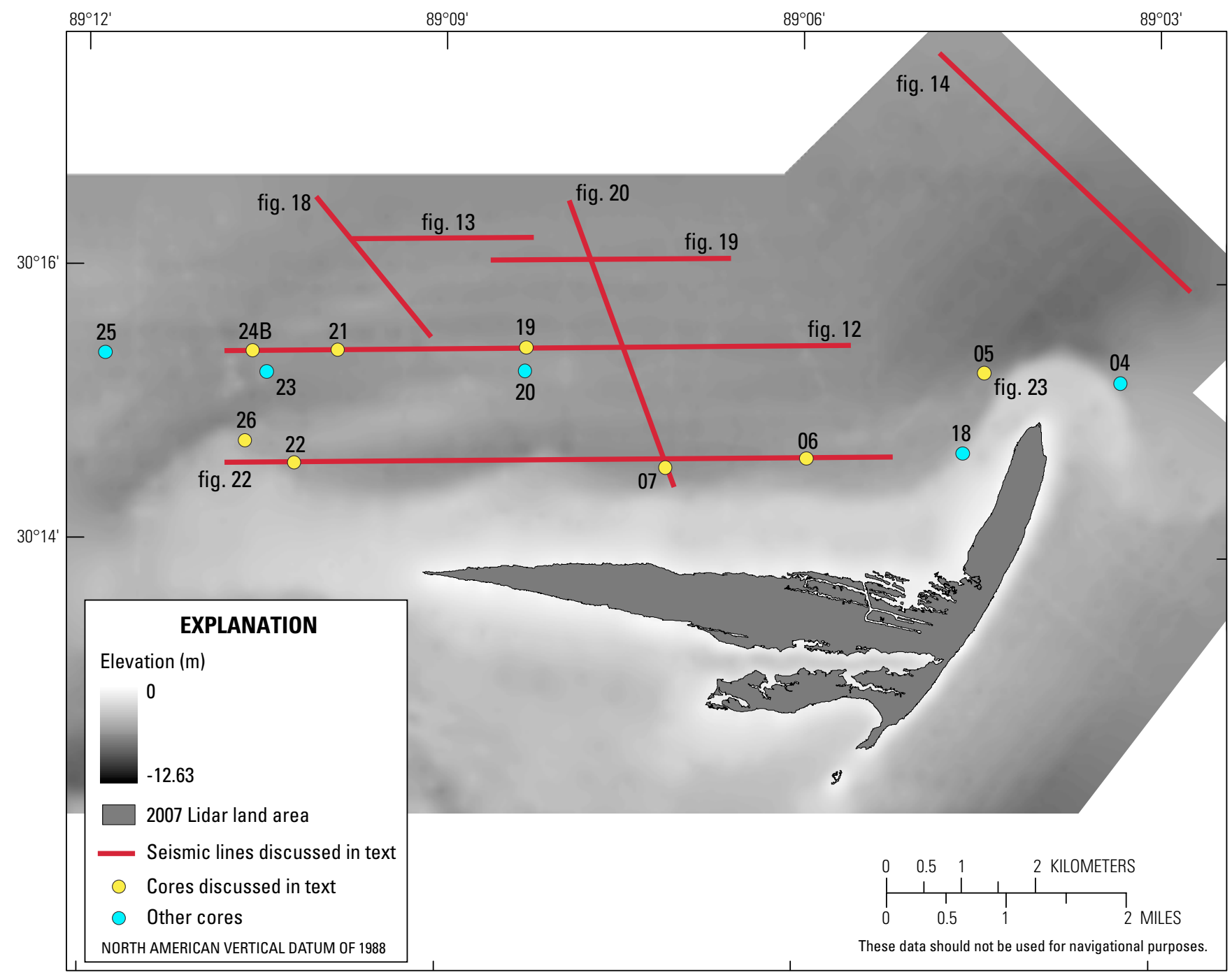

Figure 11. Map of the region north of Cat Island showing the location of seismic lines discussed in the text or in figures (red lines). Cores discussed in the text and shown in figures are represented by yellow circles. Other cores collected from this region are indicated by blue circles. Though all cores are not discussed in the text, they did contribute to interpretations presented and more detailed information about them can be found in Buster and others (2014).

medium-grained, light-brown sand with a mean grain size of 249 micrometers $(\mu \mathrm{m})$. Shell fragments are found throughout the cores (fig. 15).

The NUS unit overlies the NLS and extends outside of the study area to the north, similar to the NLS, but pinches out farther to the east than the NLS (fig. 19). The identifying seismic signature for the NUS is low-angle clinoforms to horizontal, low-amplitude bedding. The NUS covers an area of $18.55 \mathrm{~km}^{2}\left(7.162 \mathrm{mi}^{2}\right)$ with an average thickness of $1.75 \mathrm{~m}(5.3 \mathrm{ft})$ ranging from 0.0 to $5.99 \mathrm{~m}(0.0$. to $19.7 \mathrm{ft})$. Average overburden is $2.38 \mathrm{~m}(7.8 \mathrm{ft})$ with a range of 0.59 to $5.71 \mathrm{~m}$ (1.9 to $18.7 \mathrm{ft})$ (table 4$)$. Sediment volume for the NUS unit is estimated at $32.5 \mathrm{M} \mathrm{m}^{3}\left(42.5 \mathrm{M} \mathrm{yd}^{3}\right)$. This unit was sampled in cores 19, 20, 21, 23, and 24B. Olive-gray, muddy sand grades downcore to light olive-brown sand with shell fragments throughout (fig. 15). Grain-size analysis indicates a composition of greater than 90 percent fine to medium sand with a mean grain size of $242.3 \mu \mathrm{m}$ (table 4).

A unit was identified in seismic profiles north of Cat Island (fig. 20) that we interpret to be the northern extent of the antecedent Cat Island platform (AIP) (figs. 20 and 21). The AIP northern flank has 


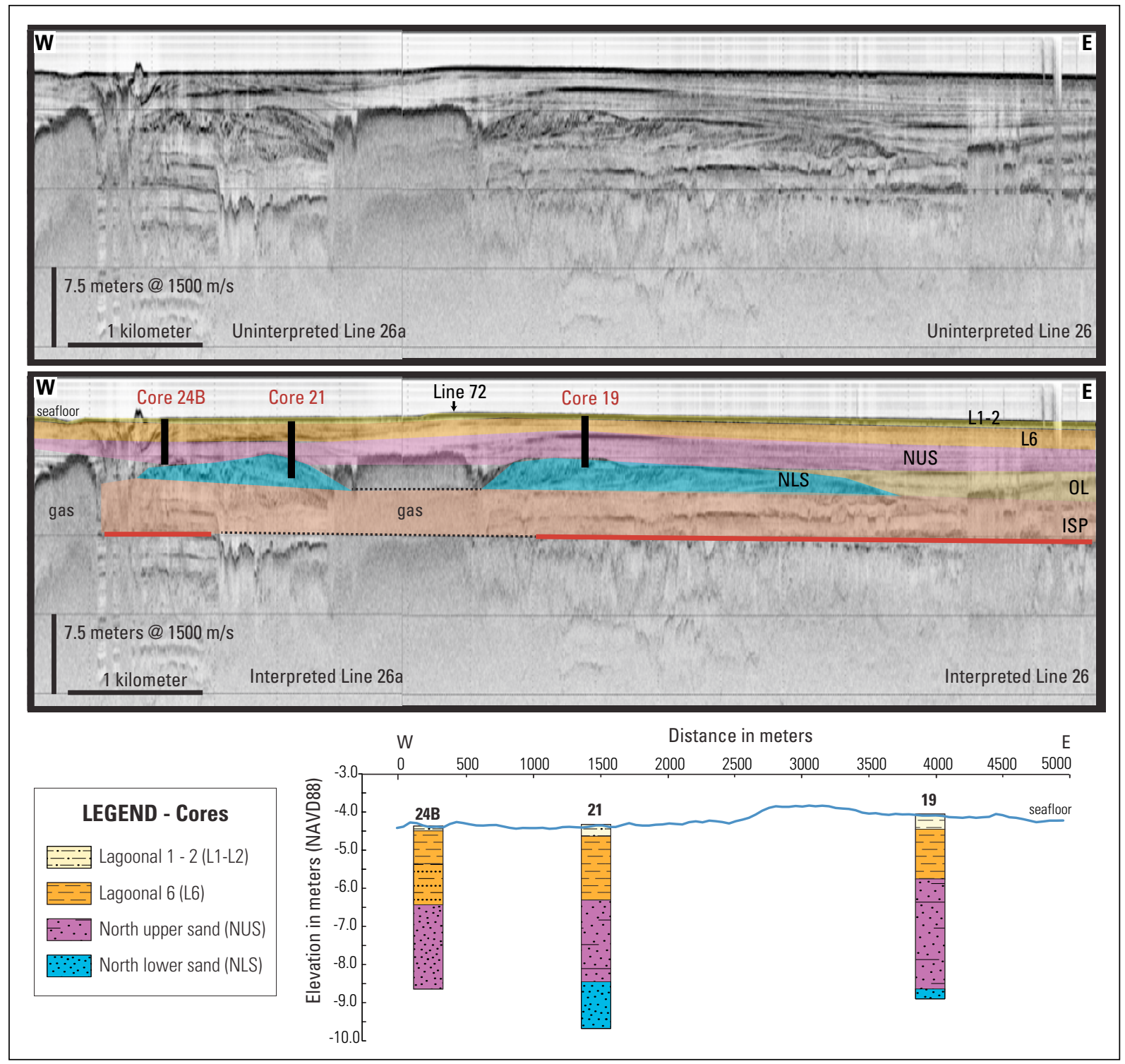

Figure 12. Uninterpreted seismic profile 26 and 26 a (upper panel) and the same profiles with interpretations (middle panel), including the locations of Cores 19, 21, and 24B, and the intersection of seismic profile 72 (fig. 18). The location of the profile is shown in figure 11. Interpreted lithologic units relative to a bathymetric profile are shown in the lower panel. Note the high lateral geologic variability, especially the high-angle clinoforms of the north lower sand (NLS) unit. The red line indicates the PleistoceneHolocene ravinement surface. For more descriptive lithologies see tables 1, 2, and 3.

two younger, stacked shoal units (island platforms 1(IP1) and 2 (IP2)) identified in seismic profiles as deposits with high-angle clinoforms, separated by a high-amplitude horizon, that sharply pinch out just off the Cat Island marginal platform (figs. 20, 21, and 22). The north-island antecedent platform (consisting of the island-platform and flanking shoal units) extends $\sim 1 \mathrm{~km}(0.62 \mathrm{mi})$ from the modern island shoreline to a steep bathymetric slope at a water depth of $\sim 4 \mathrm{~m}(13.12 \mathrm{ft})$. The antecedent-platform deposit consists of $\geq 95$ percent well-sorted, light grayish-brown, medium sand with traces of disseminated shell fragments and occasional wood fragments (fig. 21, also see south and east sections). The AIP provides a large base for the current island development. 

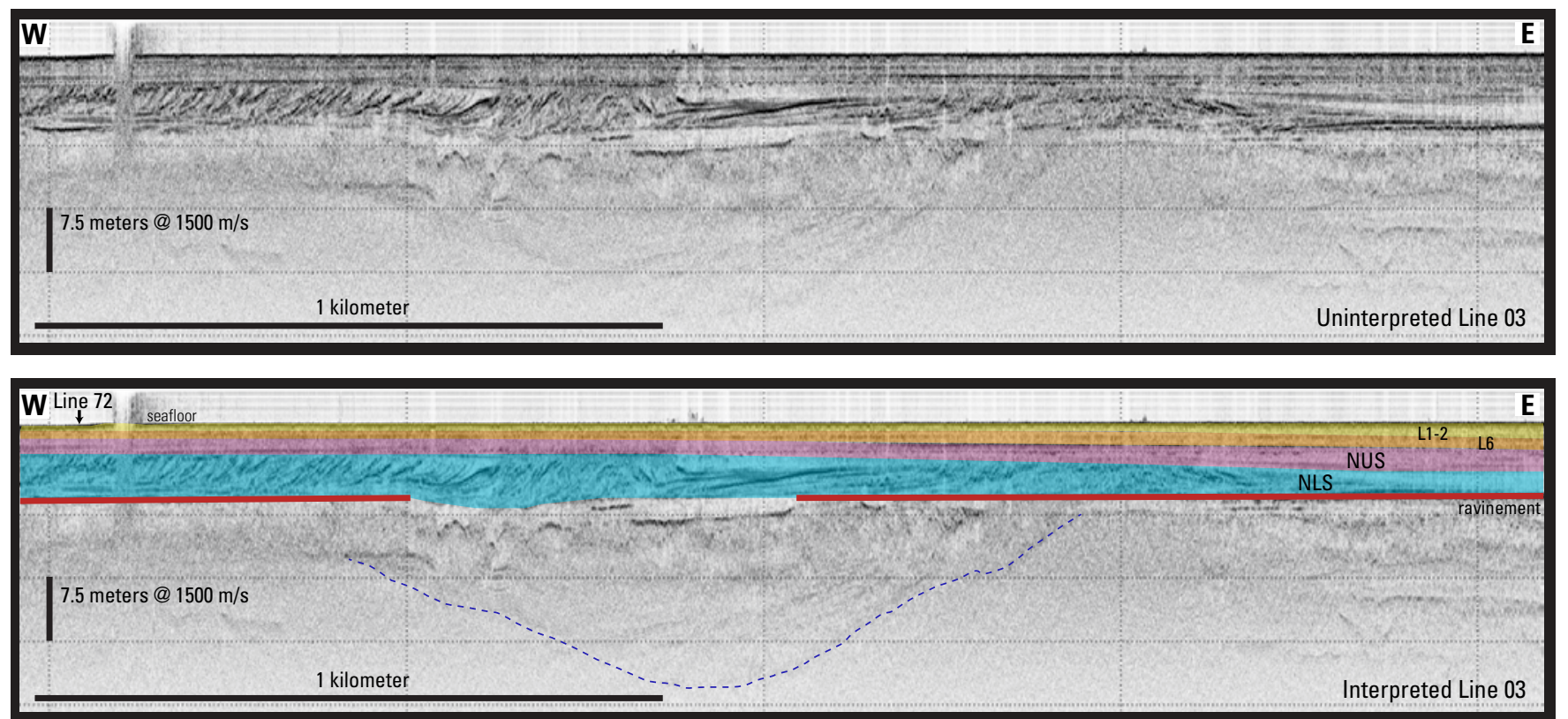

Figure 13. Uninterpreted seismic profile 03 (upper panel) and the same profile with interpretations (lower panel), including the location of a sediment-filled paleo-incised valley (dashed blue line) below the ravinement horizon (solid red line). The location of the profile is shown in figure 11. Note that the high-angle clinoforms in the north lower sand unit (NLS) appear to dip in opposite directions. For more descriptive lithologies see tables 1,2 , and 3 .

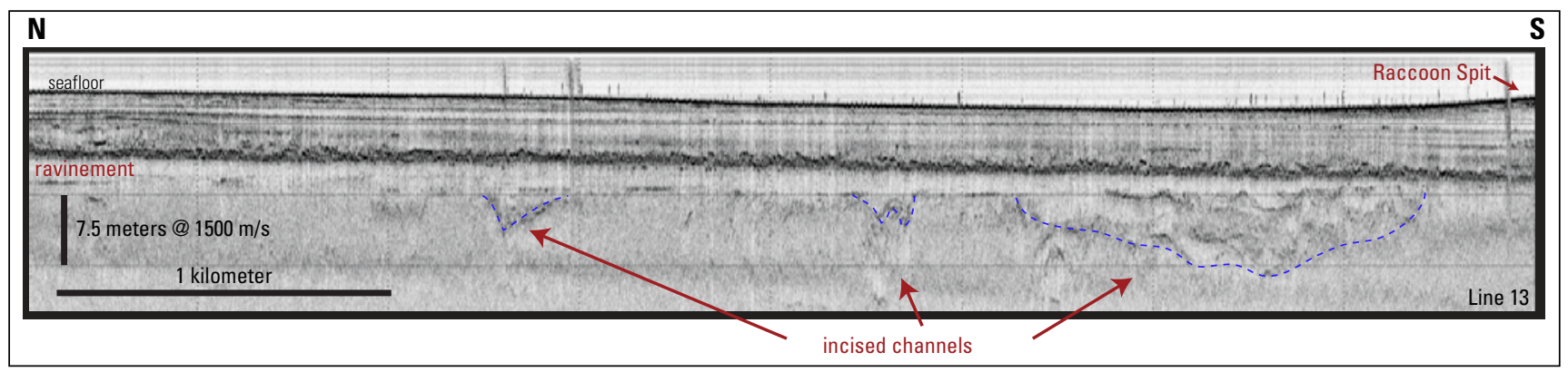

Figure 14. Uninterpreted seismic profile 13 from the northeast side of the Cat Island study area. Location of the profile shown in figure 11. The dashed blue lines indicate sediment-filled, incised valleys below the ravinement horizon. Note the ravinement dipping from north (N) to south (S). This figure shows only a segment of the ravinement slope. For more descriptive lithologies see tables 1, 2, and 3 .

Modern lagoonal/estuarine sediments of Mississippi Sound primarily overlie the NUS unit. These lagoonal/estuarine deposits onlap all other units and extend across the study area (fig. 20). The deposits are categorized into three primary stratigraphic units (L1, L2, and L6) separated by a discontinuous, lowamplitude seismic horizon. Units L3 through L5 are localized units found near the island platform between L1, L2, and L6. In seismic profiles, the lower unit (L6) is a continuous lagoonal/estuarine deposit characterized by interior, discontinuous, low-amplitude horizons with areas that are acoustically transparent (figs. $12,13,18,19$, and 20$)$. The L6 unit is $\sim 1 \mathrm{~m}(\sim 3.28 \mathrm{ft})$ thick and consists of a brownish-gray to olive-gray, relatively soft, massive deposit of medium- to very fine-grained sand with small silt lenses. In most of the north area the deposit grades into the upper units L1 and L2. The L1 and L2 units are acoustically transparent, more than $0.5 \mathrm{~m}$ thick, and consist of dark olive-gray, soft-saturated, coarse silt to very fine-grained sand (fig. 15). In the eastern part of the north study area, there has been only lagoonal/estuarine sediment deposition over the ravinement surface with little to no sand (fig. 23). 


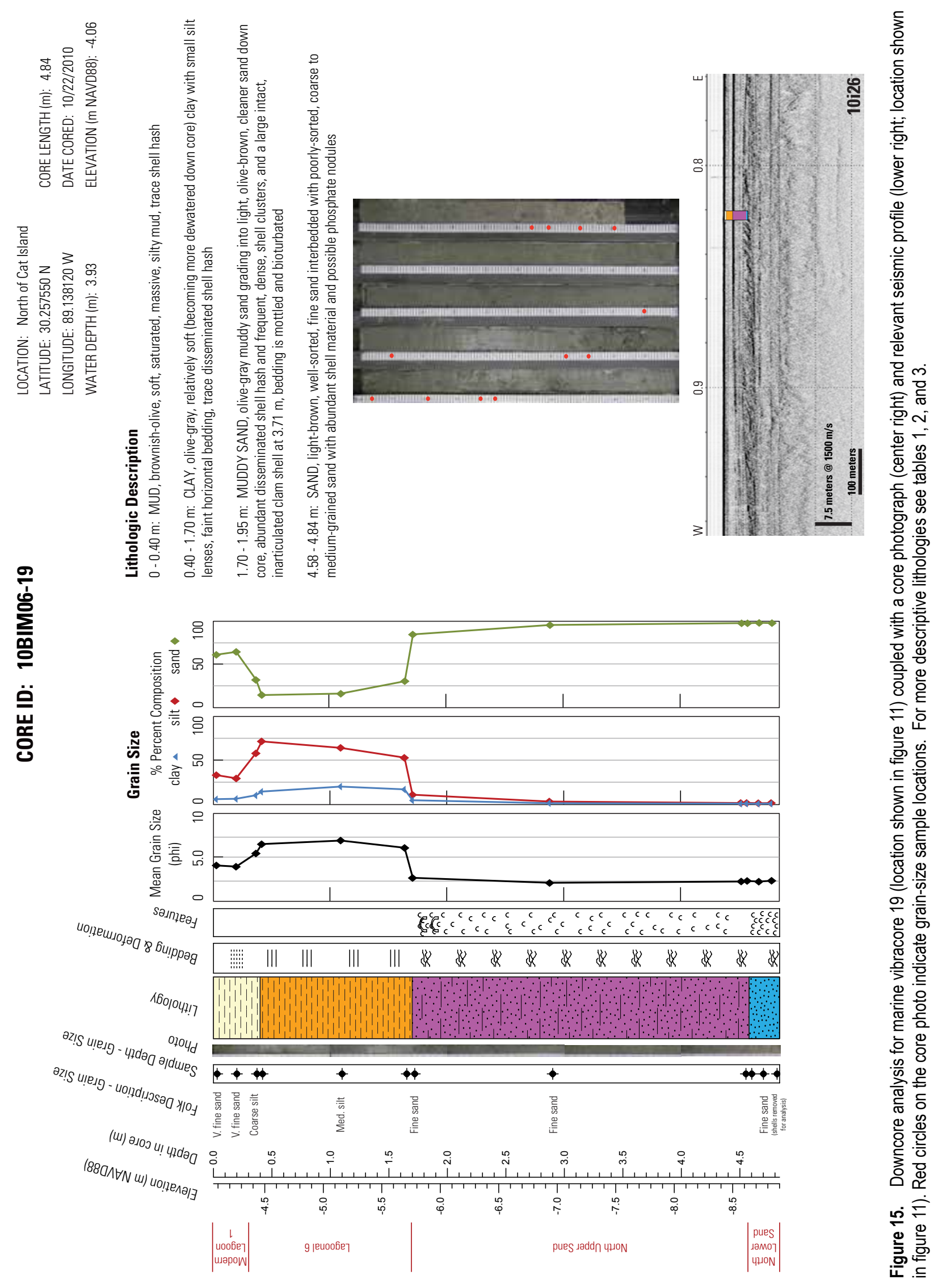




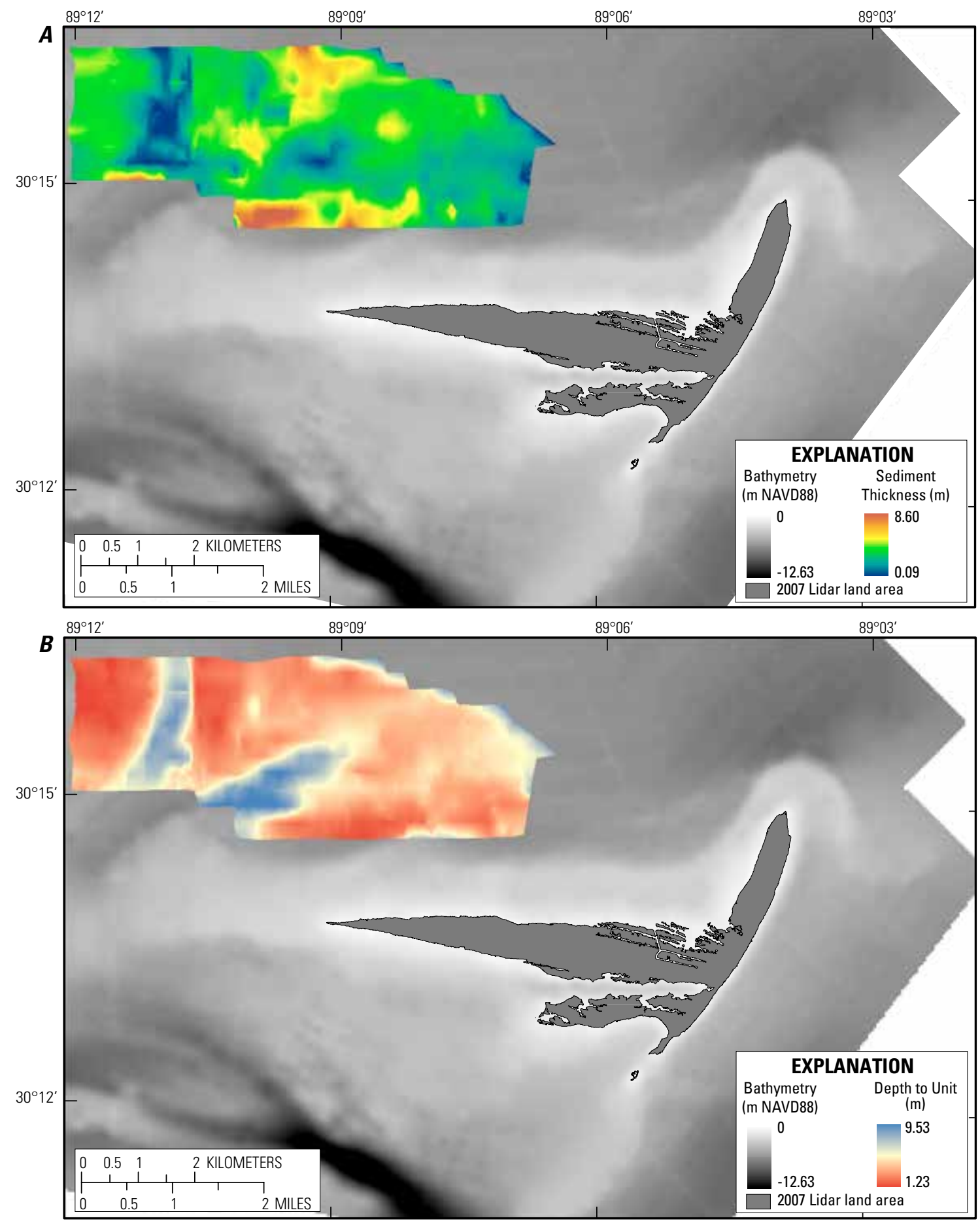

Figure 16. Maps showing (A) the extent of the north lower sand (NLS) unit and unit thickness and (B) the depth to the top of the unit. 


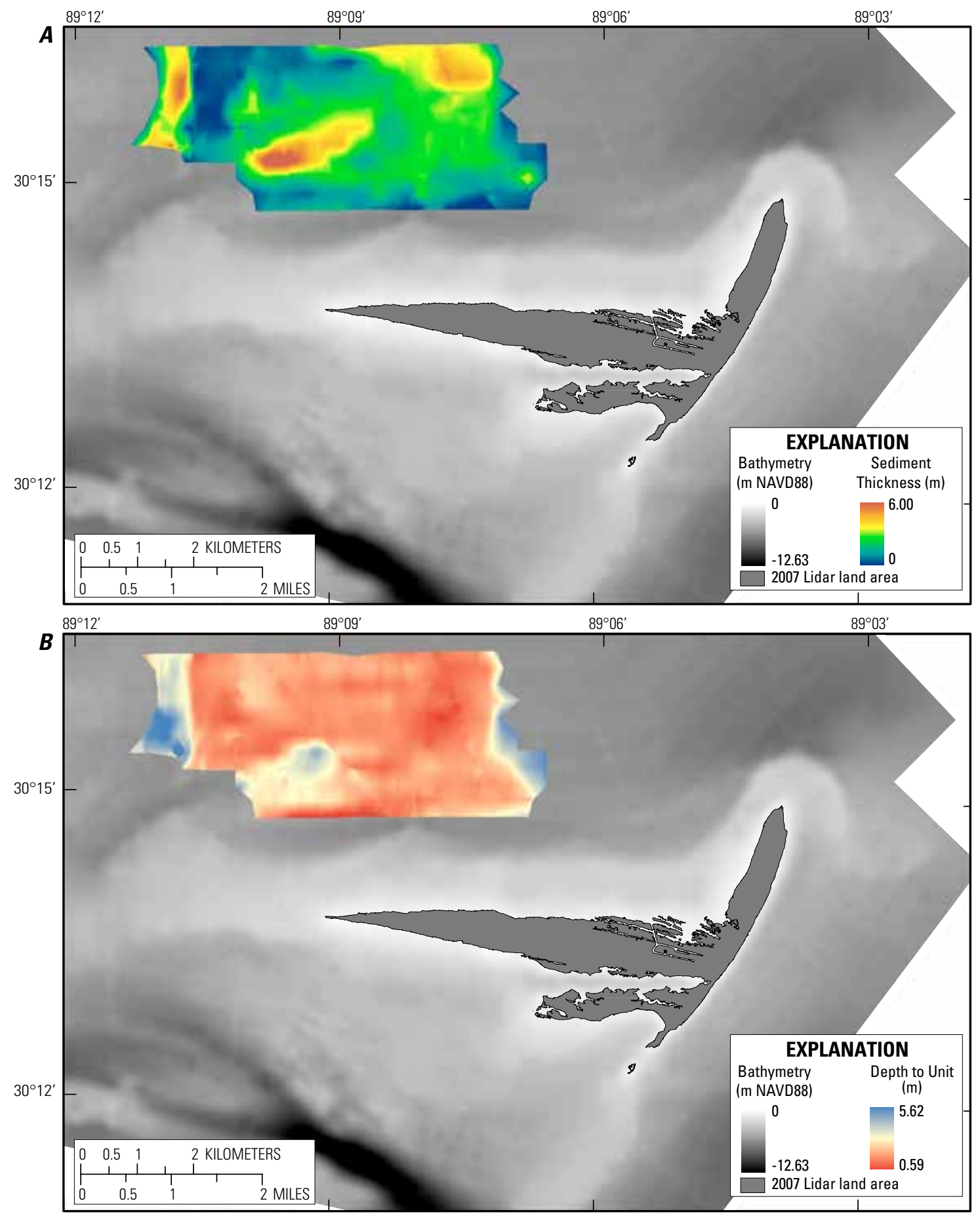

Figure 17. Maps showing (A) the extent of the north upper sand (NUS) unit and unit thickness and (B) the depth to the top of the unit. 

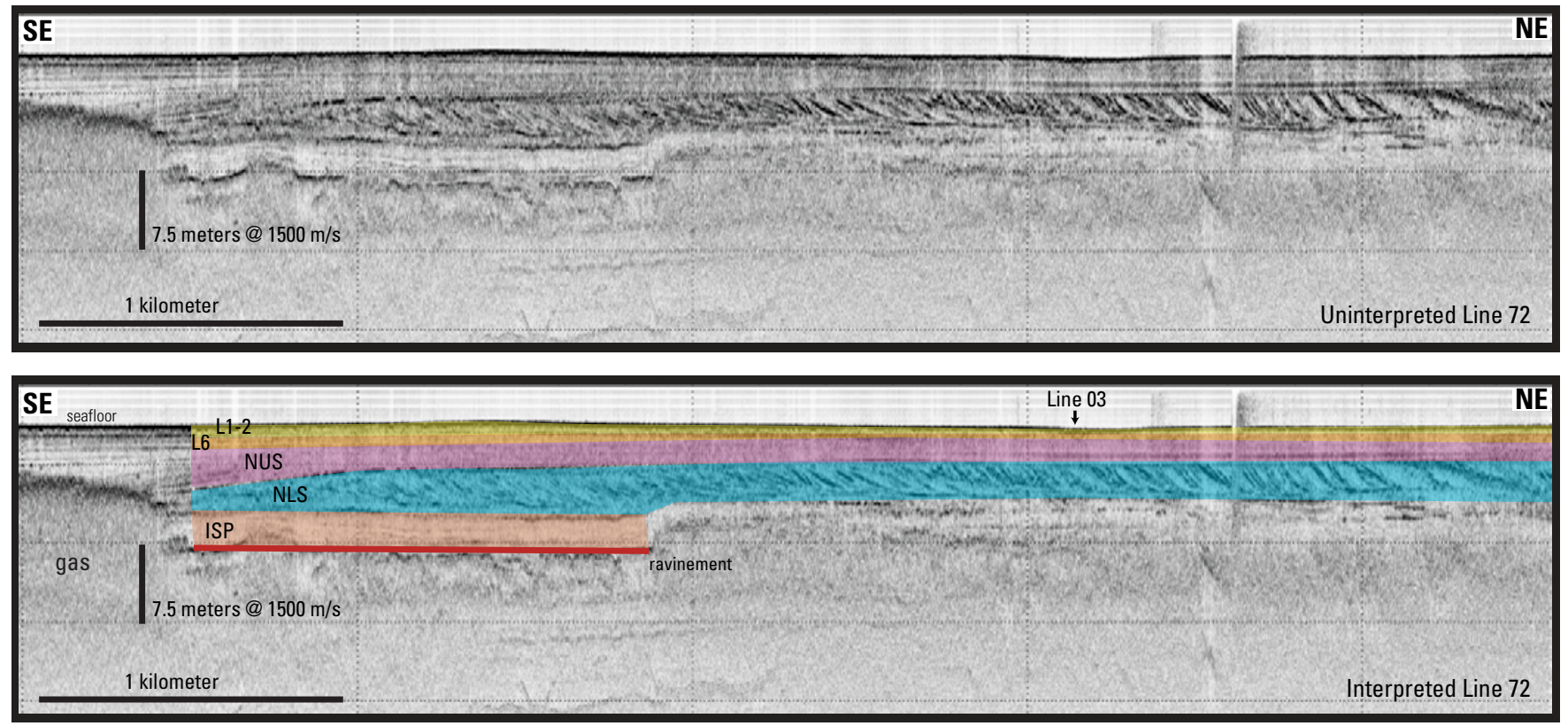

Figure 18. Uninterpreted seismic profile 72 (upper panel) and the same profile with interpretations (lower panel). The interpreted profile shows units lagoonal (L1, L2, L6), north upper sand (NUS), north lower sand (NLS), inner-shelf platform (ISP), intersection location of seismic profile 03 (fig. 13), and ravinement horizon (red line). The location of the profile is shown in figure 11. Note NLS (blue) steep clinoforms appear to dip to the north. For more descriptive lithologies see tables 1, 2, and 3.
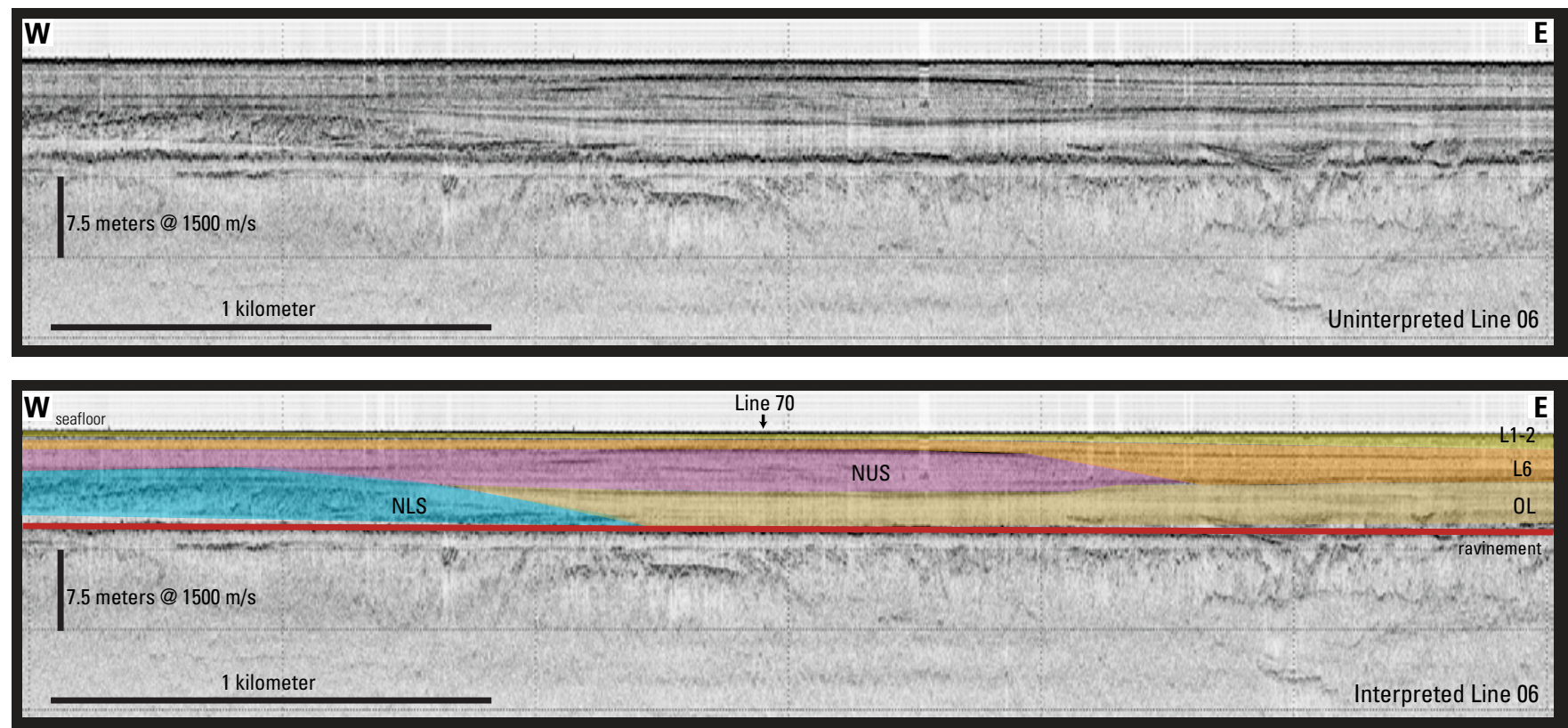

Figure 19. Uninterpreted seismic profile 06 (upper panel) and the same profile with interpretations (lower panel). The interpreted profile shows units lagoonal (L1, L2, L6), north upper sand (NUS), north lower sand (NLS), and other lagoonal (OL), the intersection location of seismic profile 70 (fig. 20), and the ravinement horizon (red line). Note the downlapping termination (pinch out) locations of the NLS and NUS units. For more descriptive lithologies see tables 1,2 , and 3 . 
Table 4. Areas, average thicknesses (with range of thicknesses), and average depths to top (with range of depths) for each of the sandy units identified in the study.

[Measurements are in meters $(\mathrm{m})$, feet $(\mathrm{ft})$, square meters $\left(\mathrm{m}^{2}\right)$, square feet $\left(\mathrm{ft}^{2}\right)$, cubic meters $\left(\mathrm{m}^{3}\right)$ and cubic feet $\left(\mathrm{ft}^{3}\right)$.]

\begin{tabular}{|c|c|c|c|c|c|c|c|c|}
\hline SAND UNITS & $\begin{array}{c}\text { Area } \\
\left(\mathrm{m}^{2}\right) / 10^{6}\end{array}$ & $\begin{array}{c}\text { Area } \\
\left(\mathrm{ft}^{2}\right) / 10^{6}\end{array}$ & $\begin{array}{l}\text { Volume } \\
\left(\mathrm{m}^{3}\right) / 10^{6}\end{array}$ & $\begin{array}{l}\text { Volume } \\
\left(\mathrm{ft}^{3}\right) / 10^{6}\end{array}$ & $\begin{array}{c}\text { Average } \\
\text { Thickness } \\
\text { (Range of } \\
\text { Thickness) (m) }\end{array}$ & $\begin{array}{c}\text { Average } \\
\text { Thickness } \\
\text { (Range of } \\
\text { Thickness) (ft) }\end{array}$ & $\begin{array}{l}\text { Average } \\
\text { Depth to top of Unit } \\
\text { (Range of } \\
\text { Depth to Unit) } \\
\text { (m) }\end{array}$ & $\begin{array}{c}\text { Average } \\
\text { Depth to top of Unit } \\
\text { (Range of } \\
\text { Depth to Unit) } \\
\text { (ft) }\end{array}$ \\
\hline NORTH UPPER SAND (NUS) & 18.6 & 199.7 & 32.5 & 1149.3 & $1.8(0-6.0)$ & $5.9(0-19.7)$ & $2.4(0.6-5.7)$ & $7.8(1.9-18.7)$ \\
\hline NORTH LOWER SAND (NLS) & 22.8 & 245.5 & 72.3 & 2554.1 & $3.2(0.1-8.6)$ & $10.5(0.3-22.2)$ & $4.3(1.2-9.7)$ & $14.0(4.0-31.8)$ \\
\hline SOUTH ANTECEDENT ISLAND PLATFORM - WEST (AIP) & 3.7 & 40.2 & 10.2 & 360.3 & $2.7(0-5.0)$ & $8.9(0-16.4)$ & $2(1.2-4.8)$ & $7.0(3.9-15.7)$ \\
\hline SOUTH ANTECEDENT ISLAND PLATFORM - EAST (AIP) & 1.1 & 12.2 & 3.7 & 130.6 & $3.3(0-5.0)$ & $10.8(0-16.4)$ & $2.3(0-5.3)$ & $7.6(0-17.3)$ \\
\hline EAST ANTECEDENT ISLAND PLATFORM (AIP) & 7.9 & 85.1 & 23.2 & 817.9 & $2.9(0-4.4)$ & $9.5(0-14.4)$ & $0(0-2.9)$ & $0.1(0-9.4)$ \\
\hline SOUTHWEST SHOAL (SWS) & 1.0 & 10.9 & 2.3 & 82.6 & $2.3(0.3-3.7)$ & $7.5(1.0-12.1)$ & $0.7(0-3.3)$ & $2.3(0-10.9)$ \\
\hline SOUTHWEST TIDAL DELTA (SWTD) & 7.8 & 84.1 & 25.2 & 889.6 & $3.22(0.4-7.5)$ & $10.6(1.3-24.6)$ & $3.8(1.4-6.3)$ & $12.3(4.5-20.8)$ \\
\hline
\end{tabular}
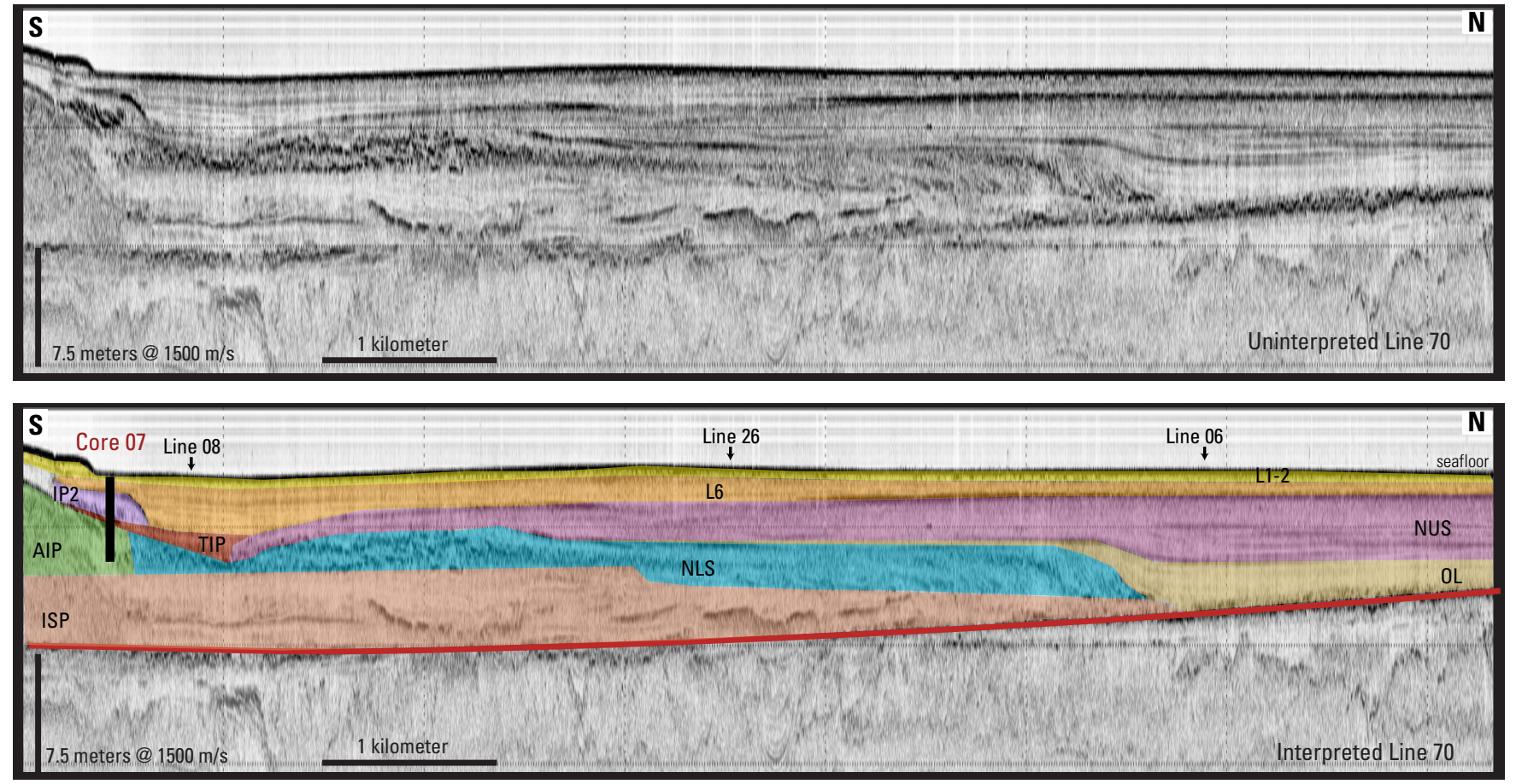

Figure 20. Uninterpreted seismic profile 70 (upper panel) and the same profile with interpretations (lower panel). The interpreted profile shows units lagoonal (L1, L2, L6), north upper sand (NUS), north lower sand (NLS), other lagoonal (OL), antecedent island platform (AIP), inner-shelf platform (ISP), transitional island platform (TIP), and island platform 2 (IP2). It also shows intersections of Lines 08, 26, and 06 (figs. 22, 12, and 19 , respectively) and the ravinement horizon (red line). The location of profile 70 is shown in figure 11. Note the northern extent of the AIP and ISP units which are also seen in seismic profiles south and east of the island. For more descriptive lithologies see tables 1, 2, and 3. 

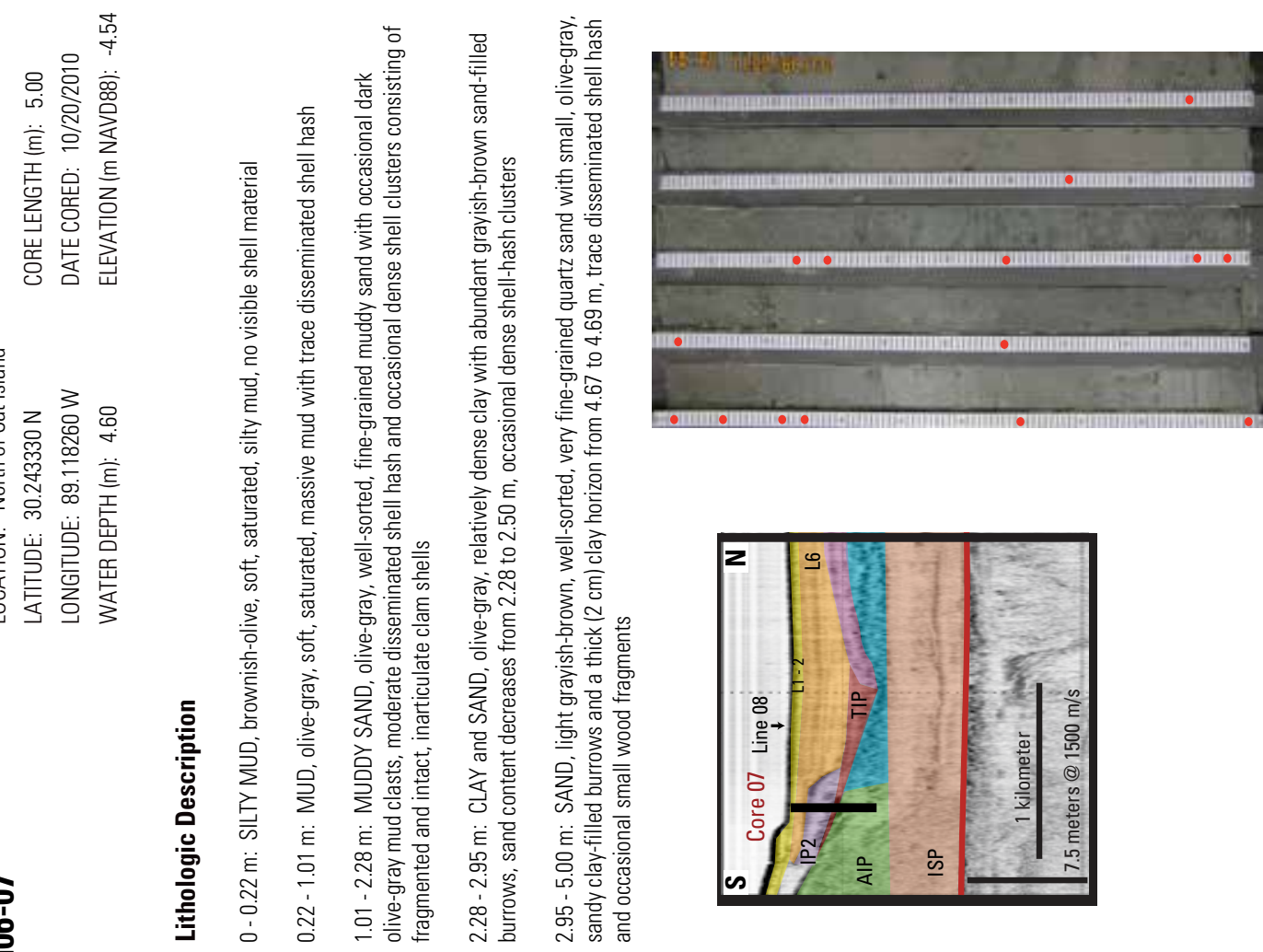

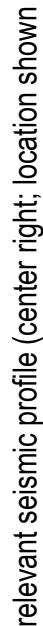

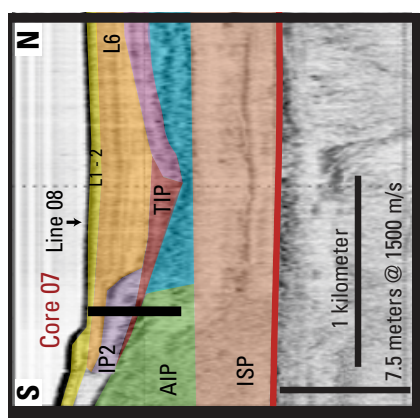

은

1ำ

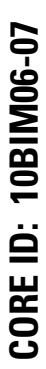
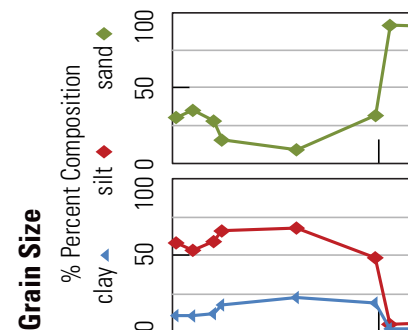

.

요은

总

覀

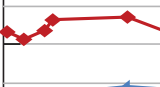

1
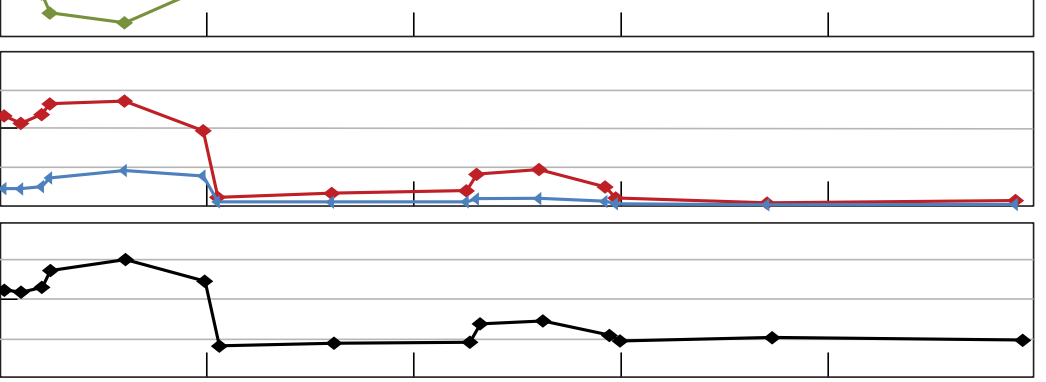

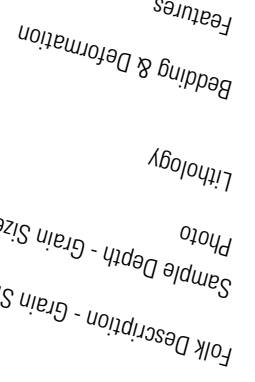

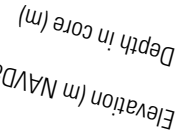

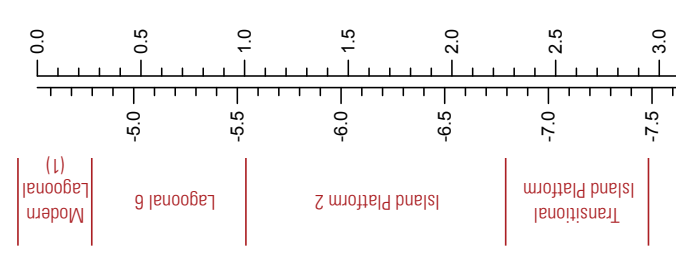

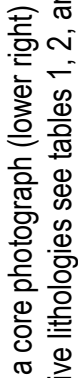

声

응

응 흠

Е

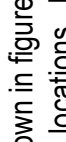

क 을

을 Nㅗㅇ

으음

윤

일

를

흥ํㅇ

永弯

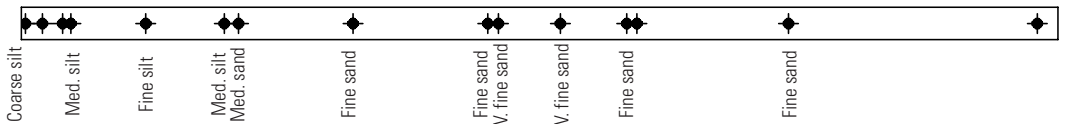

능 $\frac{\mathbb{1}}{0}$

흠 웜

$\dot{\bar{\Xi}}$

인

흐을 

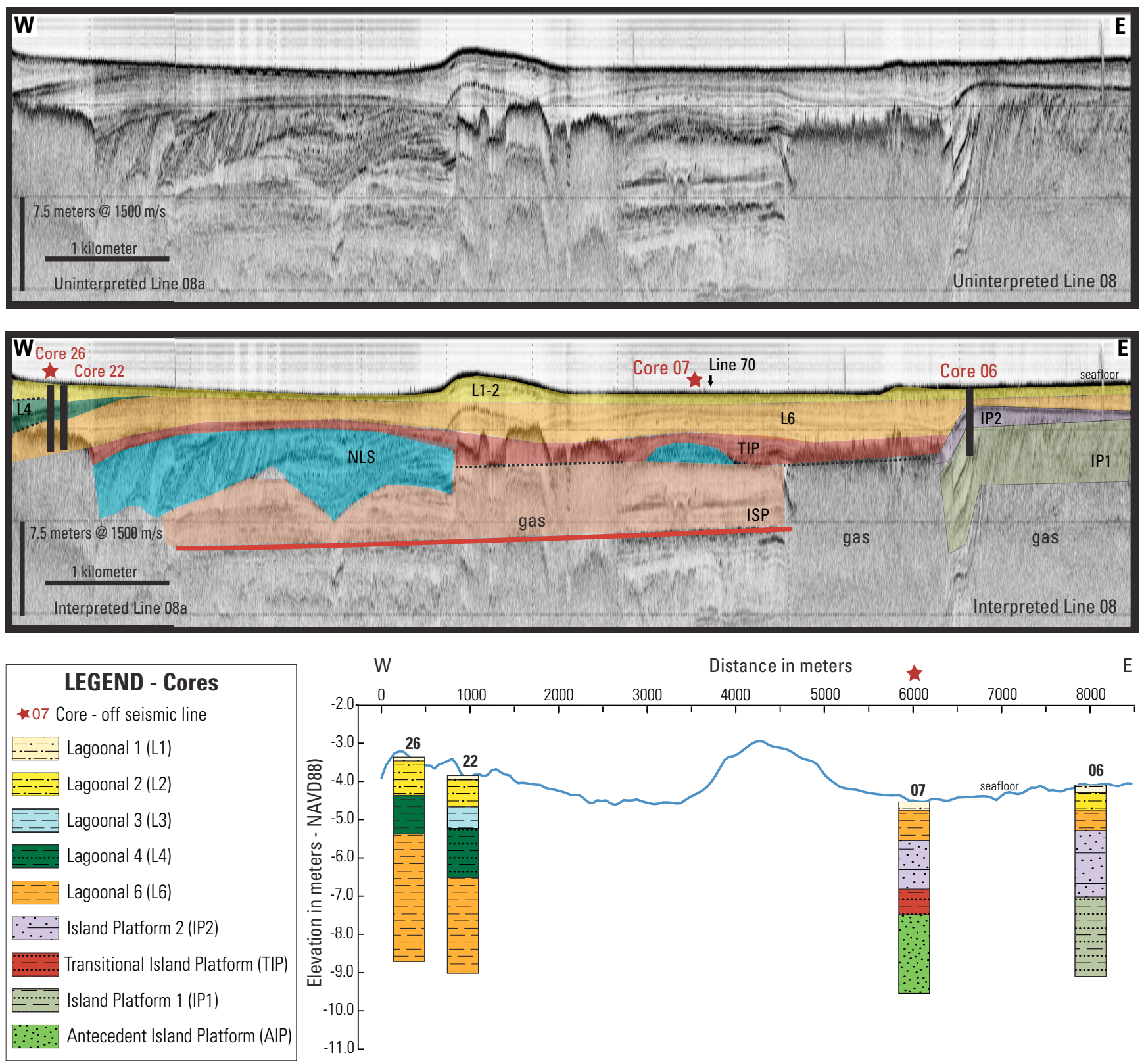

Figure 22. Uninterpreted seismic profiles 08 and 08a (upper panel) and the same profiles with interpretations (middle panel). The interpreted profile also shows units lagoonal (L1, L2, L4, L6), north lower sand (NLS), other lagoonal (OL), antecedent island platform (AIP), and island platforms 1 and 2 (IP1, IP2). The location of the intersection with seismic profile 70 (fig. 20) and ravinement horizon (red line) are also shown. The location of profiles 08 and 08 a are shown in figure 11. For more descriptive lithologies see tables 1,2, and 3. 


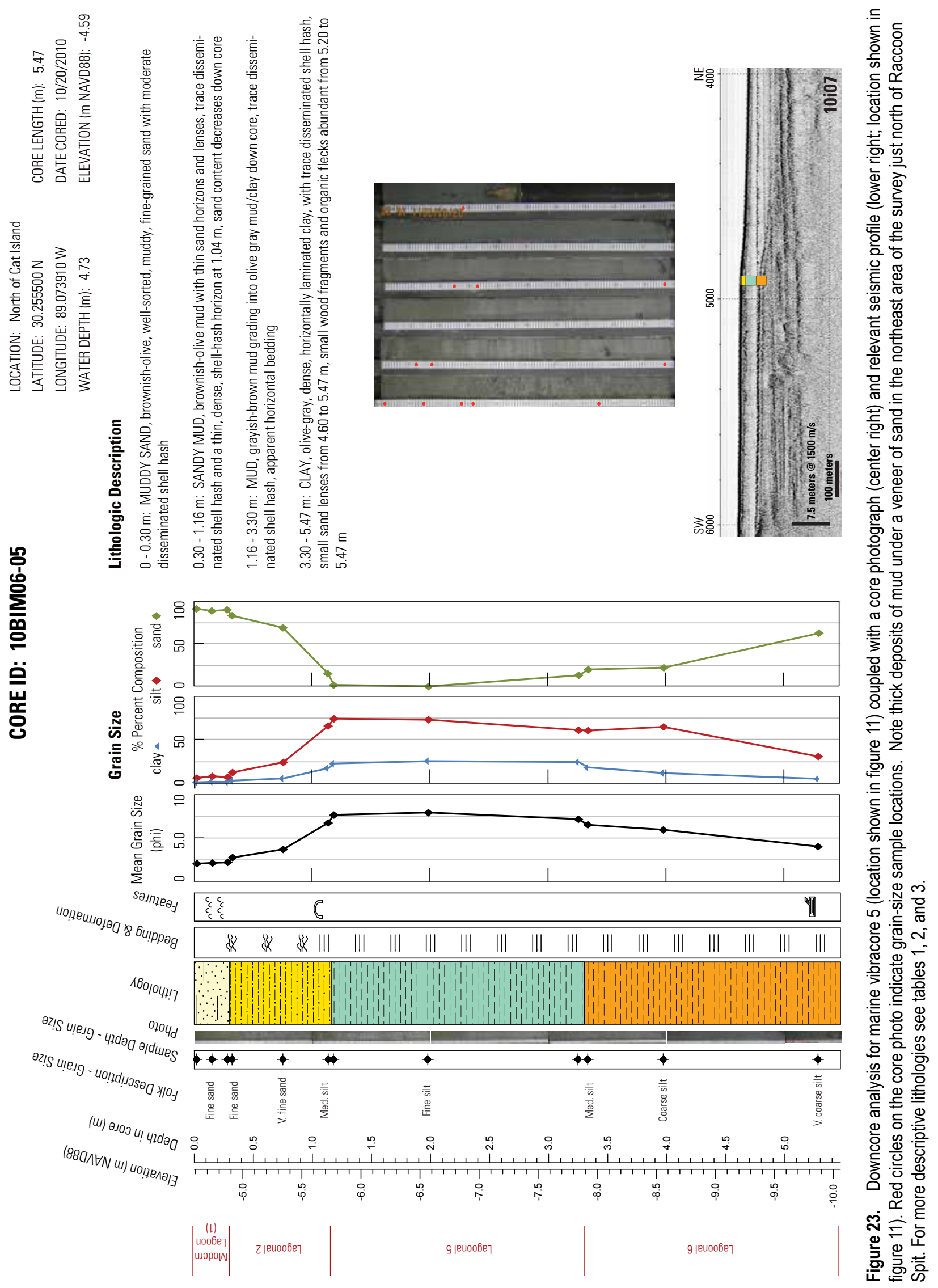




\section{Geologic and Sedimentologic History South of Cat Island}

The region south of the main part of the island and west of the southern segment of the N-S spit has a geologic and sedimentologic history different from that of the north. First, the southern region was heavily influenced by the Holocene development of the St. Bernard delta lobe of the Mississippi River (SBDL), which was a source of fine-grained, not sandy, sediments. The south side of the island has been more exposed to the wave energy of the Gulf of Mexico over geologic time than the north side, although not to the same extent as its Gulf Islands National Seashore counterparts to the east. Modern wave-related processes continually modify the seafloor morphology and sedimentology south of Cat Island through deposition of new sediment and the reworking of relict sediments. Finally, the Cat Island Channel has incised the seafloor south of the island, removing some of the stratigraphic record (fig. 10). Thirteen cores were collected from south of the island (fig. 24). Detailed core descriptions and grainsize analyses for each core are provided in Buster and others (2014). In this section, the cores collected

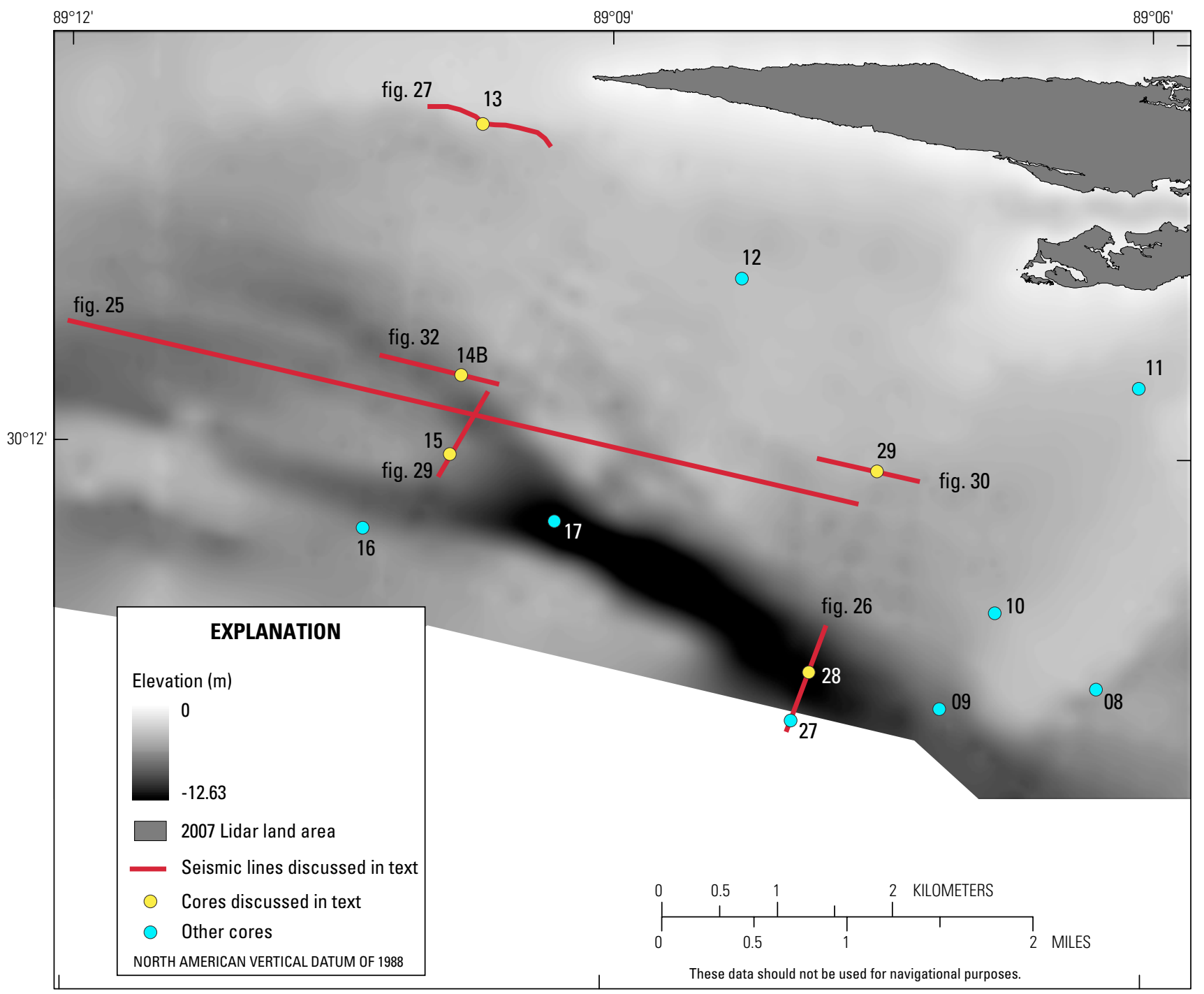

Figure 24. Map of the region south of Cat Island showing the location of seismic lines discussed in the text or in figures (red lines). Cores discussed in the text and shown in figures are represented by yellow circles. Other cores collected from this region are indicated by blue circles. Though not all cores are discussed in the text, they all contributed to interpretations presented and more detailed information can be found in Buster and others (2014). 
from south of the island are discussed in relation to surrounding seismic stratigraphy to demonstrate how various units relate to one another. The units identified, from oldest to youngest, are: inner-shelf platform (ISP), southwest tidal delta (SWTD), St. Bernard delta 1 (SB1), antecedent-island platform (AIP), southwest shoal (SWS), St. Bernard delta 2 (SB2), modern shelf (M 1-5) (fig. 25). Characteristics of major lithologic units are summarized in tables 1,2 , and 3 , and maps showing the extent and thickness of sandy deposits that might be viable for coastal-restoration projects are also discussed.

Seismic profile 77a was collected south of the island and longitudinally parallel to the island (figs. 5 and 25). Though no cores were collected along this line, interpretations from seismic profiles on either side, where core information does exist, were extrapolated to this line, which shows many of the units discussed and their complex, discontinuous stratigraphy. The ISP was the deepest unit south of Cat Island sampled with vibracores and the sample was collected in the thalweg of Cat Island Channel.
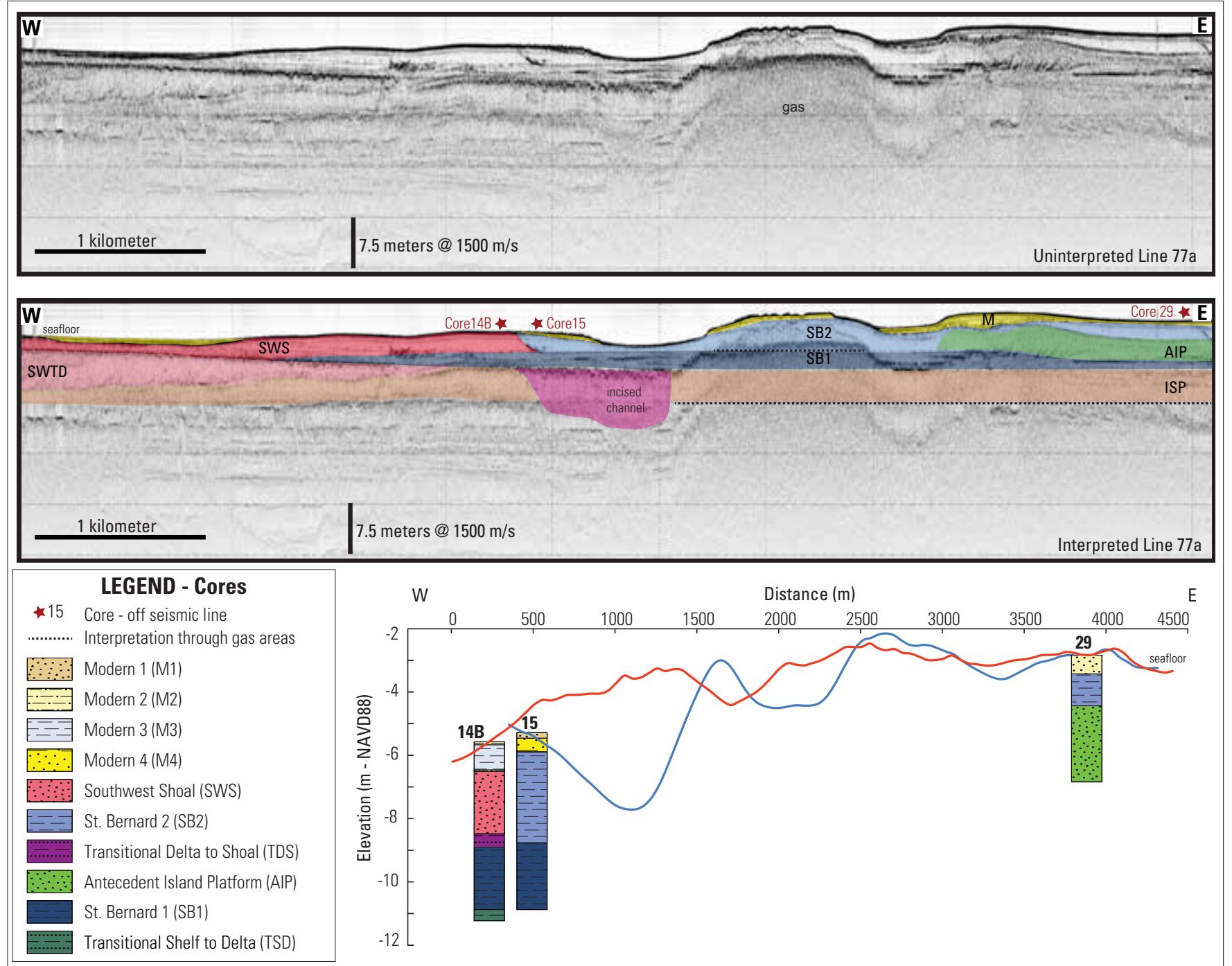

Figure 25. A non-interpreted (upper) and interpreted (lower) seismic-reflection profile from south of Cat Island shows all units identified. The profile location is shown in figure 24. Dashed lines on the lower profile indicate interpretation through gas in the sediments. The lower right panel demonstrates the vertical relation between units identified in separate cores by hanging the cores from bathymetric profiles. Though none of the cores shown in the profile were collected directly on this line, their locations are projected to this line via extrapolation from other seismic lines. For more descriptive lithologies see tables 1,2 , and 3. 
Because the channel incised the seafloor and removed overlying strata, we were able to sample normally unreachable sedimentologic units with standard $6 \mathrm{~m}(\sim 20 \mathrm{ft})$ vibracore barrel lengths. Access to these lower units allow for a more complete understanding of the geologic history of the northern Gulf of Mexico and Cat Island itself. Core 28 penetrated the ISP deposit at -13 m (42.6 ft) (NAVD88) and is characterized as muddy sand with $\sim 90$ percent sand and $\sim 10$ percent mud (orange; fig. 26). Seismic lines south of the island indicate the ISP unit thins to the west (fig. 25), and seismic lines east of the island (discussed in the next section) indicate that it slopes seaward from the mainland. Given its elevation within the stratigraphic section, its relation to other units, and its regional morphology, this unit is interpreted to represent the inner shelf prior to development of the SBDL south of the island. The muddy sand of the ISP is separated from deltaic deposits above it (discussed below) by a thin deposit $(\sim 30 \mathrm{~cm})$ composed of fine sand and shell hash, characteristic of a transgressive flooding surface (transitional shelf to delta deposit (TSD)) (fig. 26). This supports a scenario in which the sea level rose before the progradation of the delta into the study area, consistent with our interpretation.

The sandy SWTD unit southwest of Cat Island was only sampled in core 13 approximately $4 \mathrm{~m}$ (13.12 ft) below the seafloor (-5.9 m (19.4 ft), NAVD88, fig. 27). The SWTD is composed of medium sand with sand content decreasing and silt content increasing downcore (fig. 27). Seismic data show that the SWTD thickens to the west and rises to within about $1 \mathrm{~m}(3.28 \mathrm{ft})$ of the seafloor toward its eastern boundary (figs. $28 A$ and 28B). The SWTD unit's acoustic character consists of internal prograding reflection surfaces that dip to the east. The overall morphology of the feature indicates that it originated west of Cat Island (fig. 25). The combined lithology, acoustic characteristics, and morphology of the SWTD imply that it may have been part of a larger tidal delta that existed west of Cat Island during a lower sea level period and prior to development of the SBDL in the study area.

South of Cat Island, the SBDL is composed of two distinct deltaic units (SB1 and SB2). The lower unit (SB1) is composed of coarse silt with locally-dense shell fragment clusters, resulting in horizontal laminations that distinguish this unit from the non-laminated one above it (SB2) in the seismic profiles (fig. 29). The upper unit (SB2) is acoustically transparent and composed of fine silt (fig. 29). Though this lithologic description is based on the core shown in figure 29, grain-size analysis from all cores where the SB1 and SB2 units were sampled indicates spatial variability in grain size and composition (Buster and others, 2014). This is expected due to (1) the distances between cores, which probably vary in distance from the sediment source, and (2) the variability in deltaic depositional environments. Regardless of spatial variability within each unit, neither SB1 nor SB2 contain more than 25 percent sand content; therefore, isopachs for these units are not shown. The acoustic and sedimentologic characteristics of these units and their extent south of the island indicate that they are delta deposits related to Mississippi River Delta development in the northern Gulf of Mexico.

The AIP is a progradational unit identified and sampled in cores 11-13 and 29, and has a sand content of almost 100 percent (fig. 30). The fine- to medium-grained sand in the unit's top portion often shows evidence of bioturbation, with mud-filled burrows that decrease in frequency downcore, suggesting deposition in an intertidal environment. Seismic profiles show that the unit extends to the west and south of Cat Island, and demonstrate that these deposits are found exclusively adjacent to the modern island footprint. Furthermore, isopachs indicate that the AIP unit thins to the west and south, which is morphologically consistent with the modern island platform (figs. $31 A$ and $31 B$ ). In a few places, the SB2 unit (light blue) onlaps the AIP unit, which progrades westward and southward (green; fig. 25). In other places, modern sediments rest directly atop the AIP unit. The lithologic composition and distribution of the AIP unit, in addition to its stratigraphic relationship to deltaic deposits, suggest that SB2 and AIP are contemporaneous. 


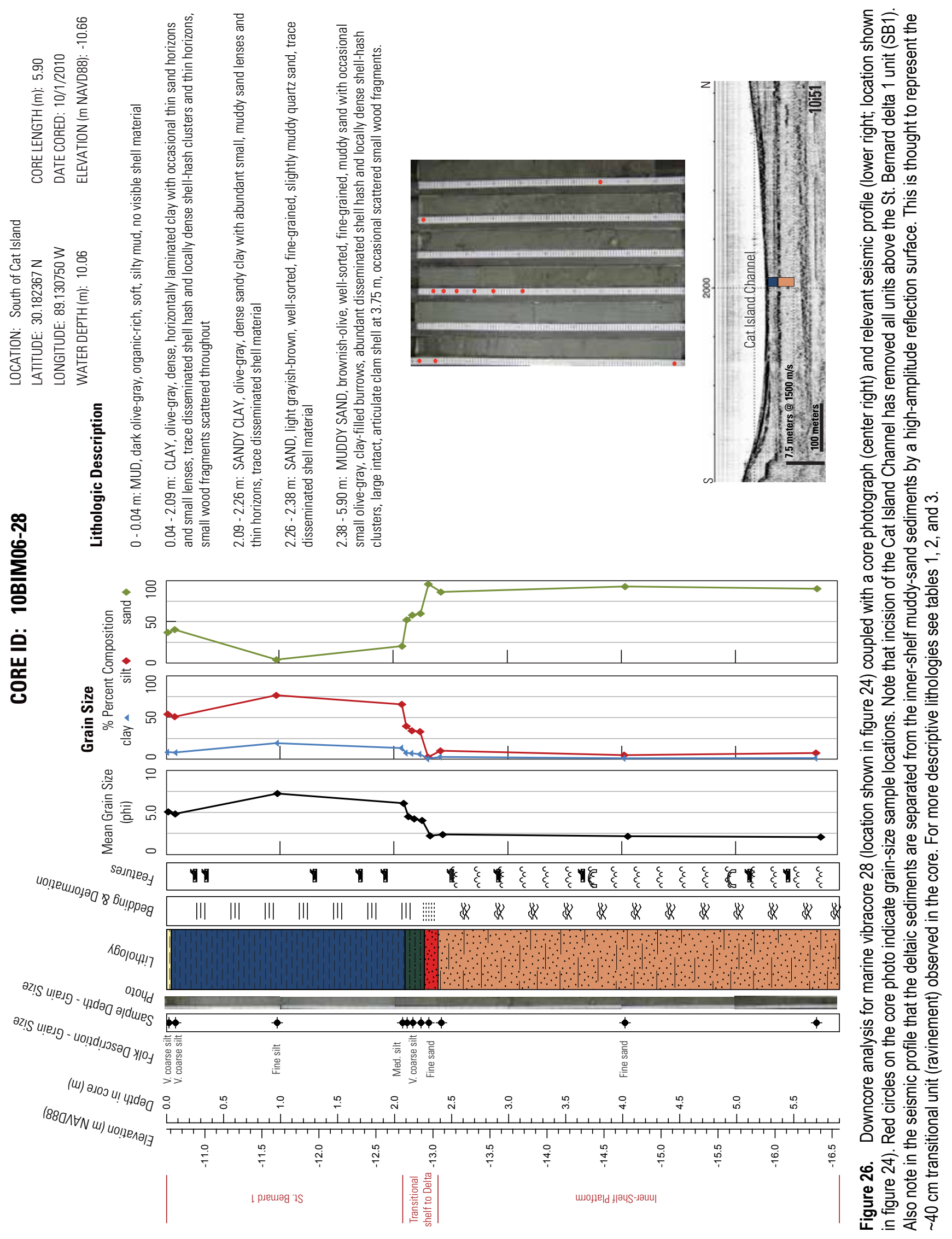



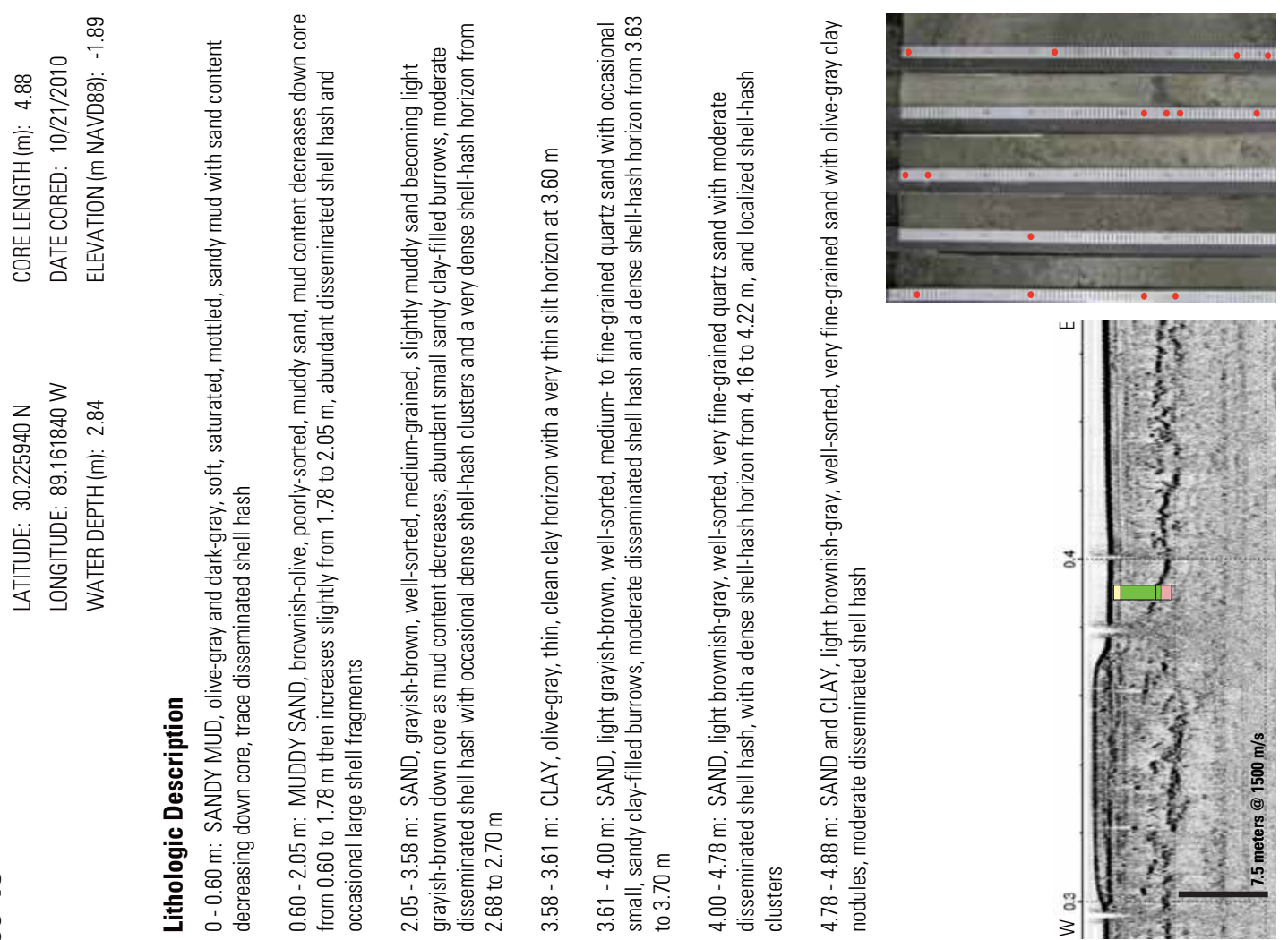

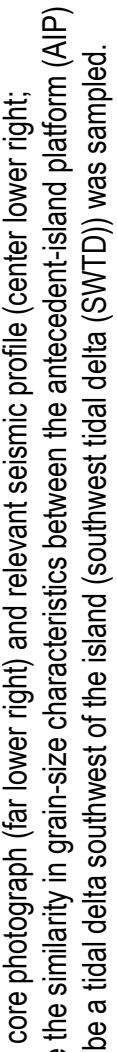
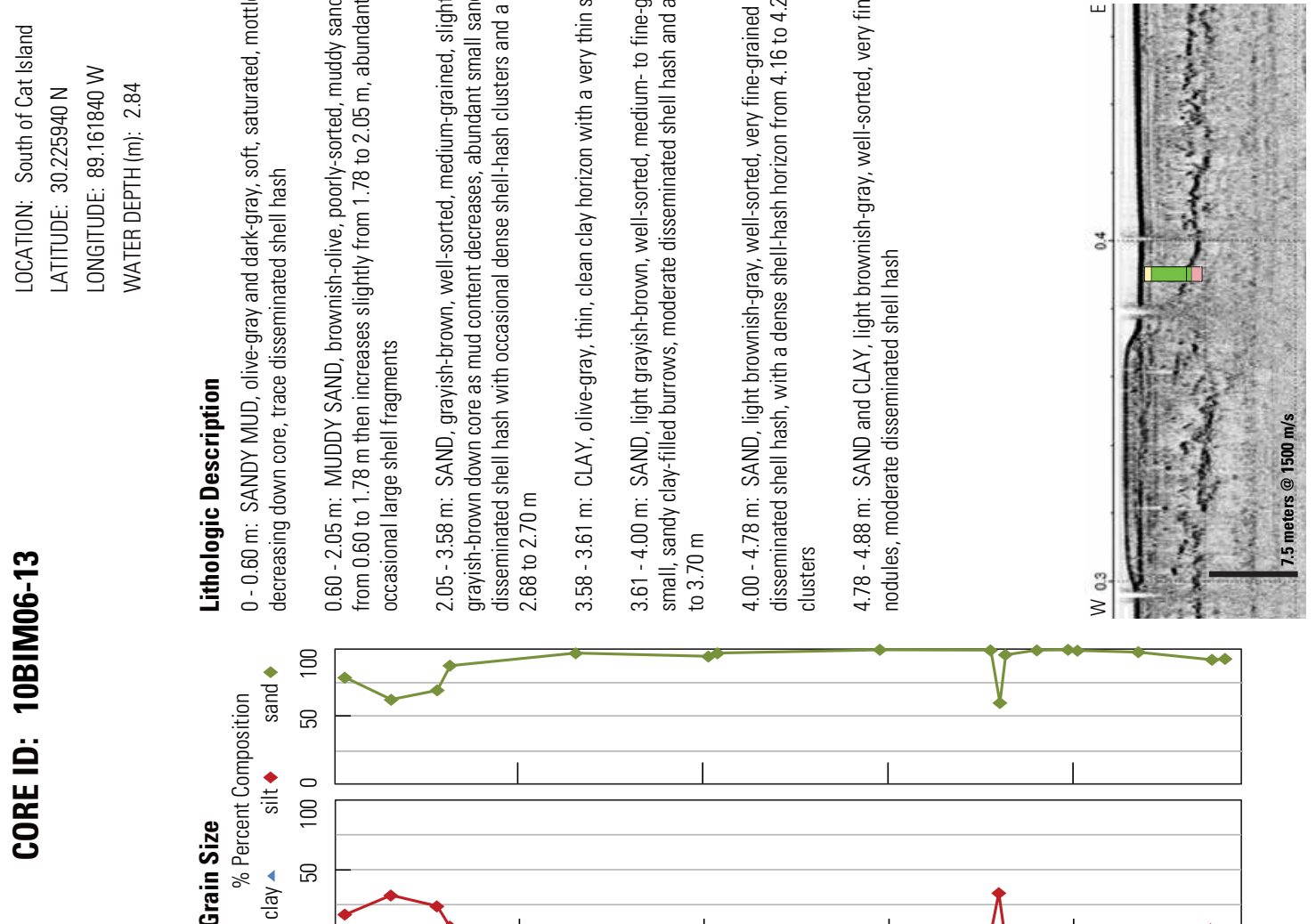

$\pi$ 잉

言安

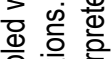

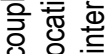

文 응

는

은

$\subseteq \frac{N}{5}$

당.

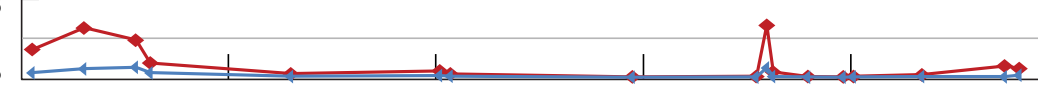

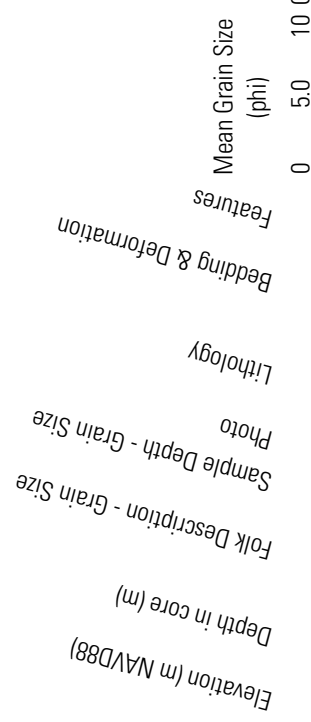
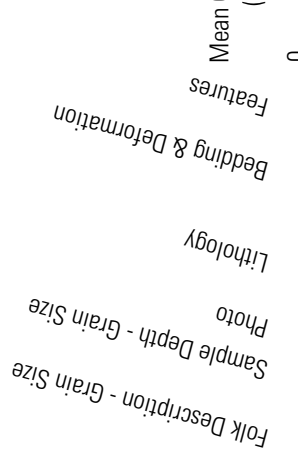
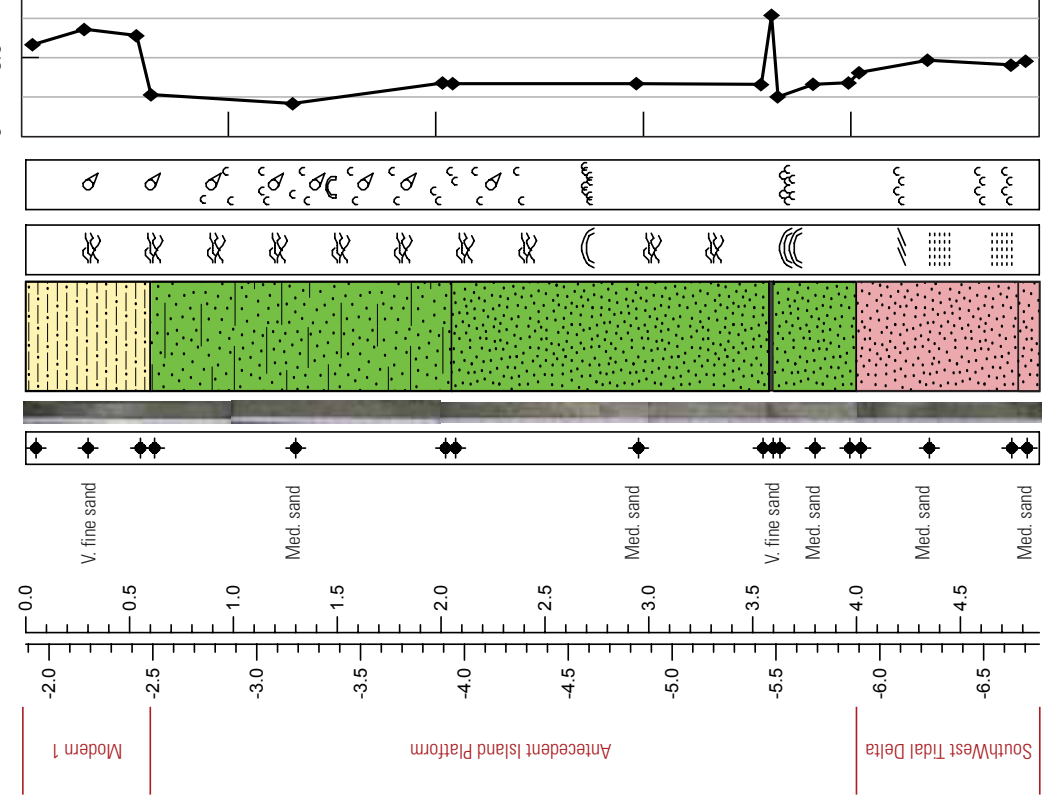

등

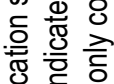

응

음음

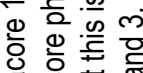

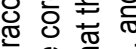

资

๘

휴 $\frac{0}{0}$

흐 흥 웡

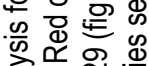

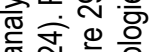

인

은 흔

文.

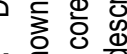

त क

인 을.

흔 으은 혼 

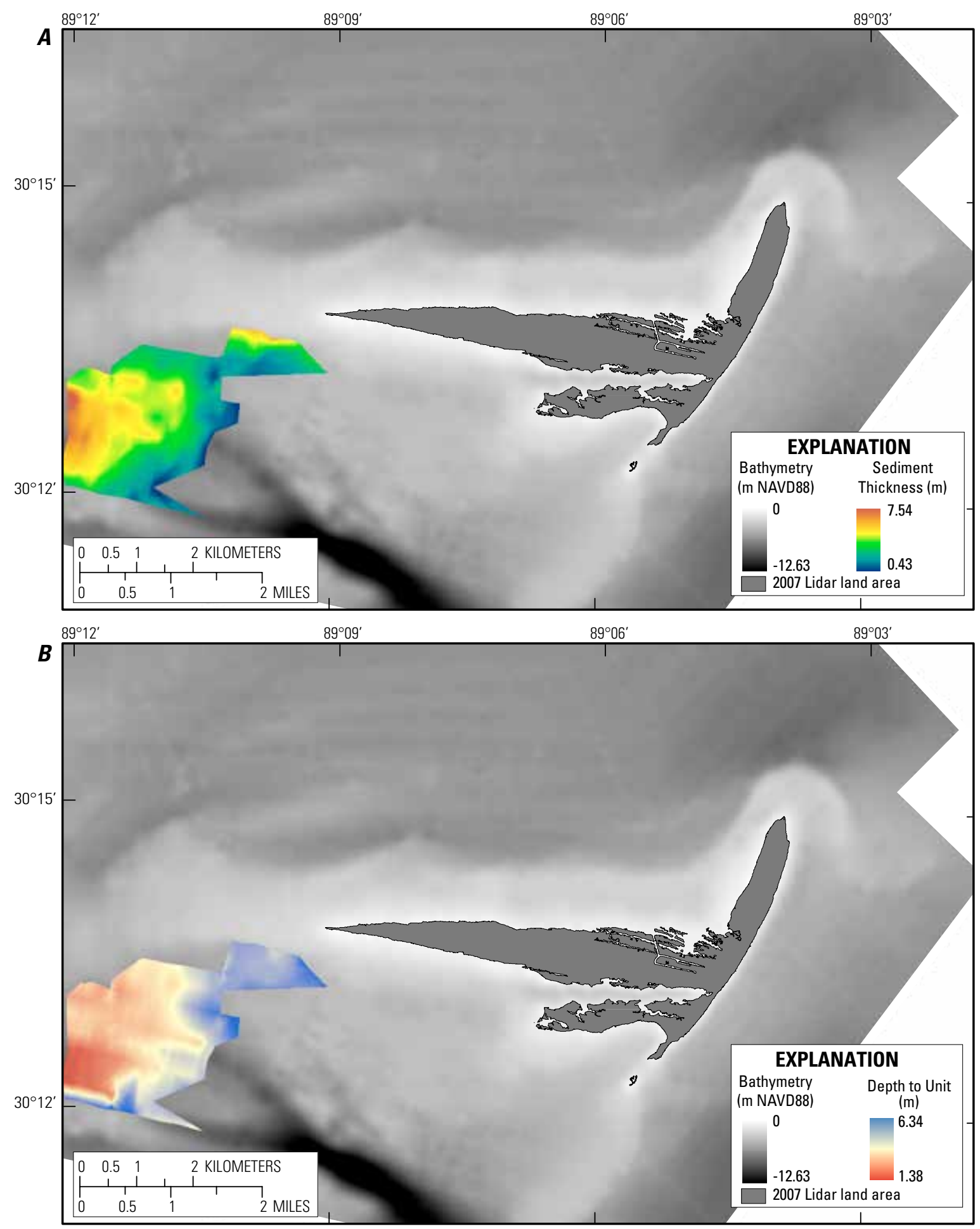

Figure 28. Maps showing $(A)$ the extent of the southwest tidal delta (SWTD) unit and unit thickness and $(B)$ the depth to the top of the unit. The interpreted relict tidal delta thickens to the west, suggesting a formation process originating west of the island. As it thins to the east, it becomes deeper beneath the seafloor surface. Note that the depth to the unit reaches a minimum of less than 1.5 meters to the west. 


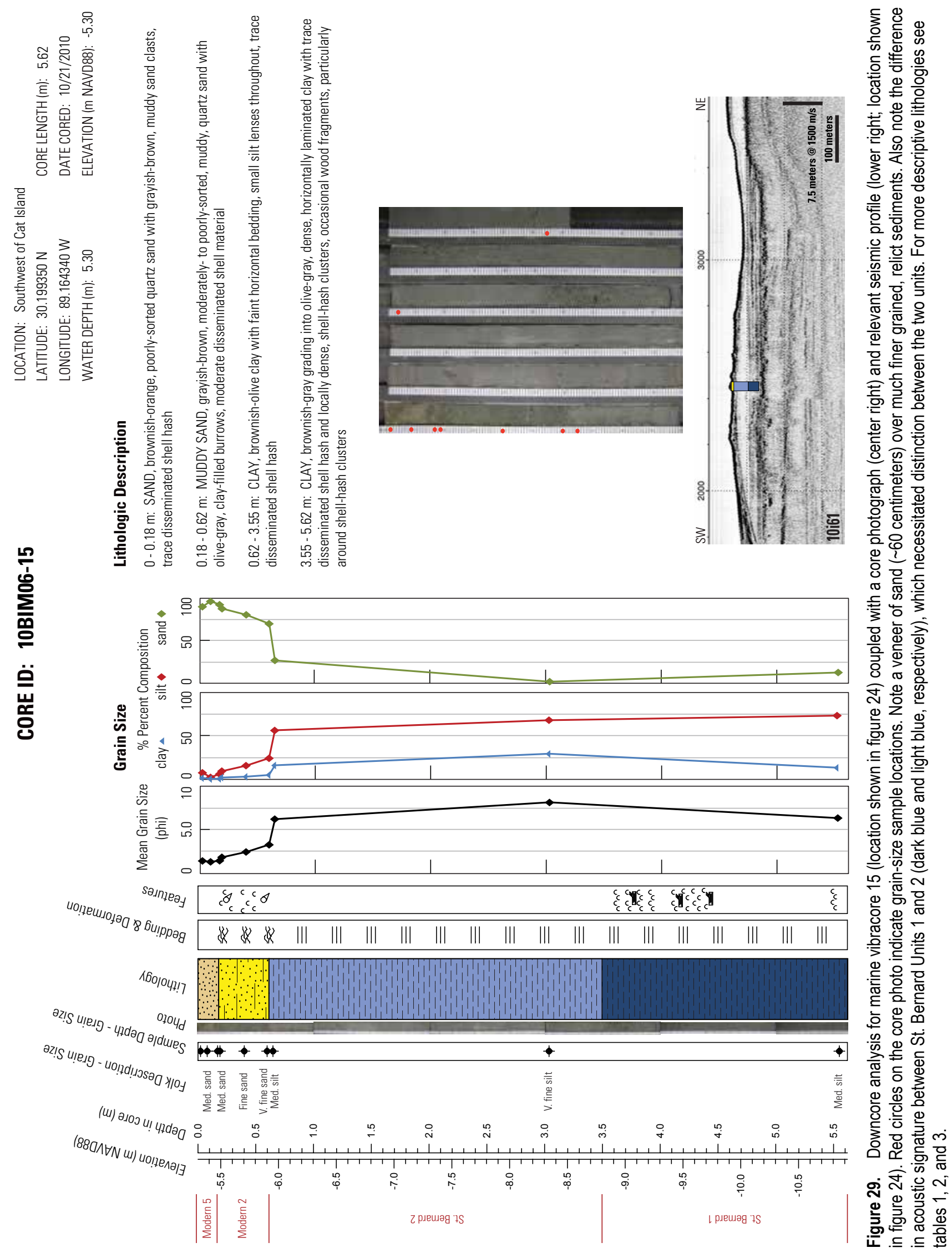




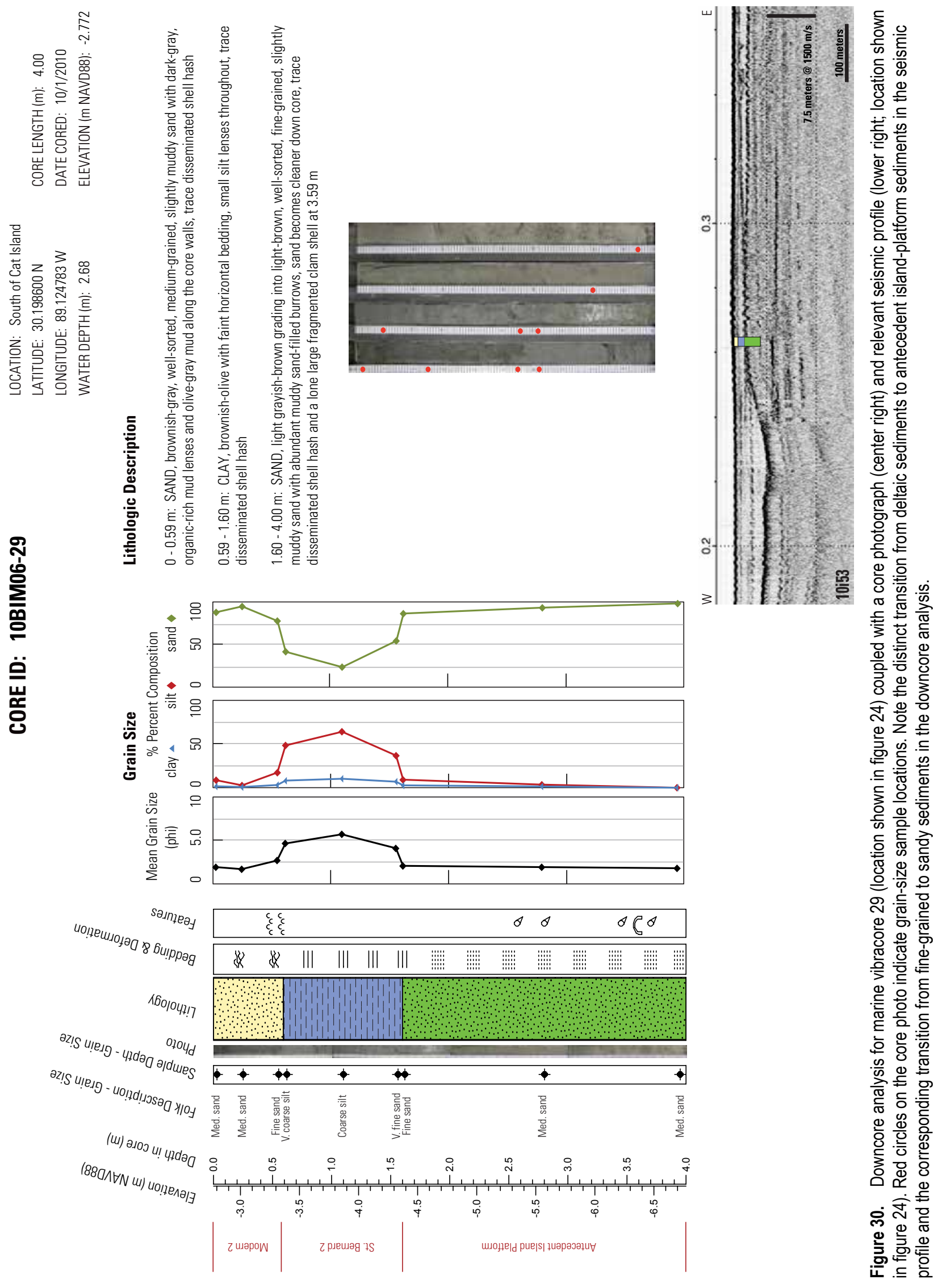



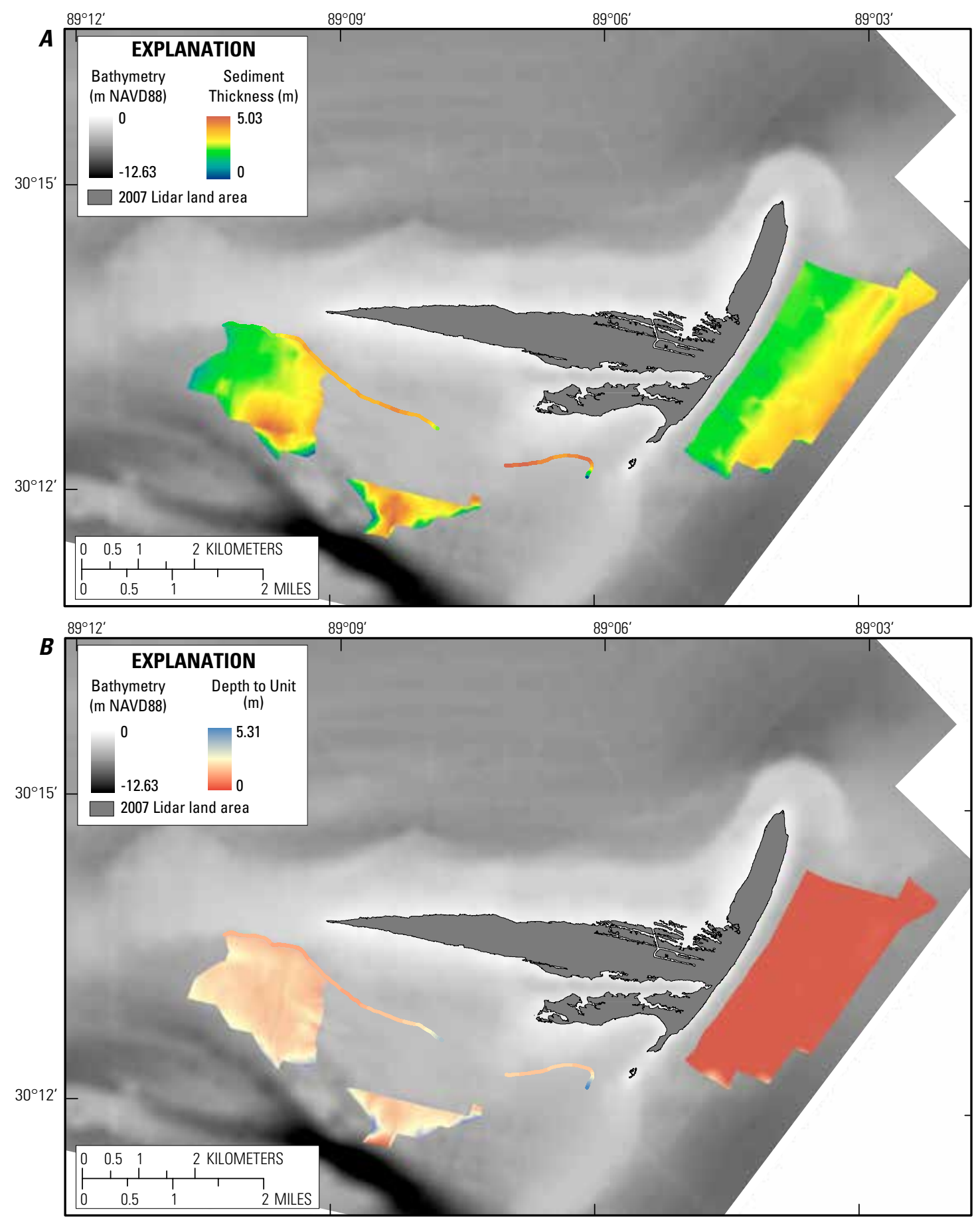

Figure 31. Maps showing $(A)$ the southern and eastern extent of the antecedent island platform (AIP) unit and unit thickness and $(B)$ the depth to the top of the unit. The line close to the island's southern shoreline shows thicknesses measured from one seismic line collected in shallow water around the island (location show in figure 6). Note the data gap between that line and the polygons to the south. Generally the deposits thin away from the island and to the west, exhibit morphology consistent with the modern island platform. Thicknesses measured on the eastern side of the island were limited by gas in the sediments and seismic-signal penetration. Therefore, the thicknesses measured closer to the island do not thin as expected and represent a conservative estimate of the thickness of the antecedent island-platform unit. Note that the unit intersects the seafloor (depth to unit $=0$ ) on the east of the island except where it pinches out at its southern edge. 
In addition to the SWTD and AIP units, there is another sandy unit (SWS) southwest of Cat Island. The SWS deposit is younger than the SB1 deposit and overlies it before the SB1 unit pinches out to the west in seismic profile 77a (fig. 25). Its sandy lithology and discrete structure imply that this unit was a sandy shoal, and vibracore 14B indicates that it is composed of almost 100 percent medium sand. This unit was also heavily bioturbated, displaying frequent mud-filled burrows. Though this unit was only sampled in core 14B (fig. 32), its extent can be mapped between seismic lines, and the data reveal that it is not extensive (figs. $33 A$ and $33 B$ ).

The uppermost unit in the stratigraphic section is the modern unit (M 1-5), which includes present seafloor sediments (yellow). Figures 25 and 29 show the modern unit (M 1-5) overlying two older units delineated in shades of blue. These units were sampled in cores 8-10, 14B, 15-17, and 27-28. Though it is shown as one color in the interpreted cross section, sediment composition varies spatially and is separated into separate units based on the core descriptions (Buster and others, 2014). Transitions in surficial sediment are shown by the variation in backscatter around the island where higher backscatter (lighter colors) represents sandier sediments and lower backscatter (darker colors) represents muddier sediments (fig. 34). In general, higher-backscatter sediments associated with the island platform extend farther offshore south and east of the island when compared with the north. These sediments make up the modern island platform, which has a shallower gradient on the south side of the island than on the north (fig. 10). Surficial seafloor grain size of the modern unit on the south side of the island ranges from medium silt to medium sand. It is important to note that where sand exists at the seafloor surface, it is often only a veneer over much finer grained, relict sediments (fig. 29). 


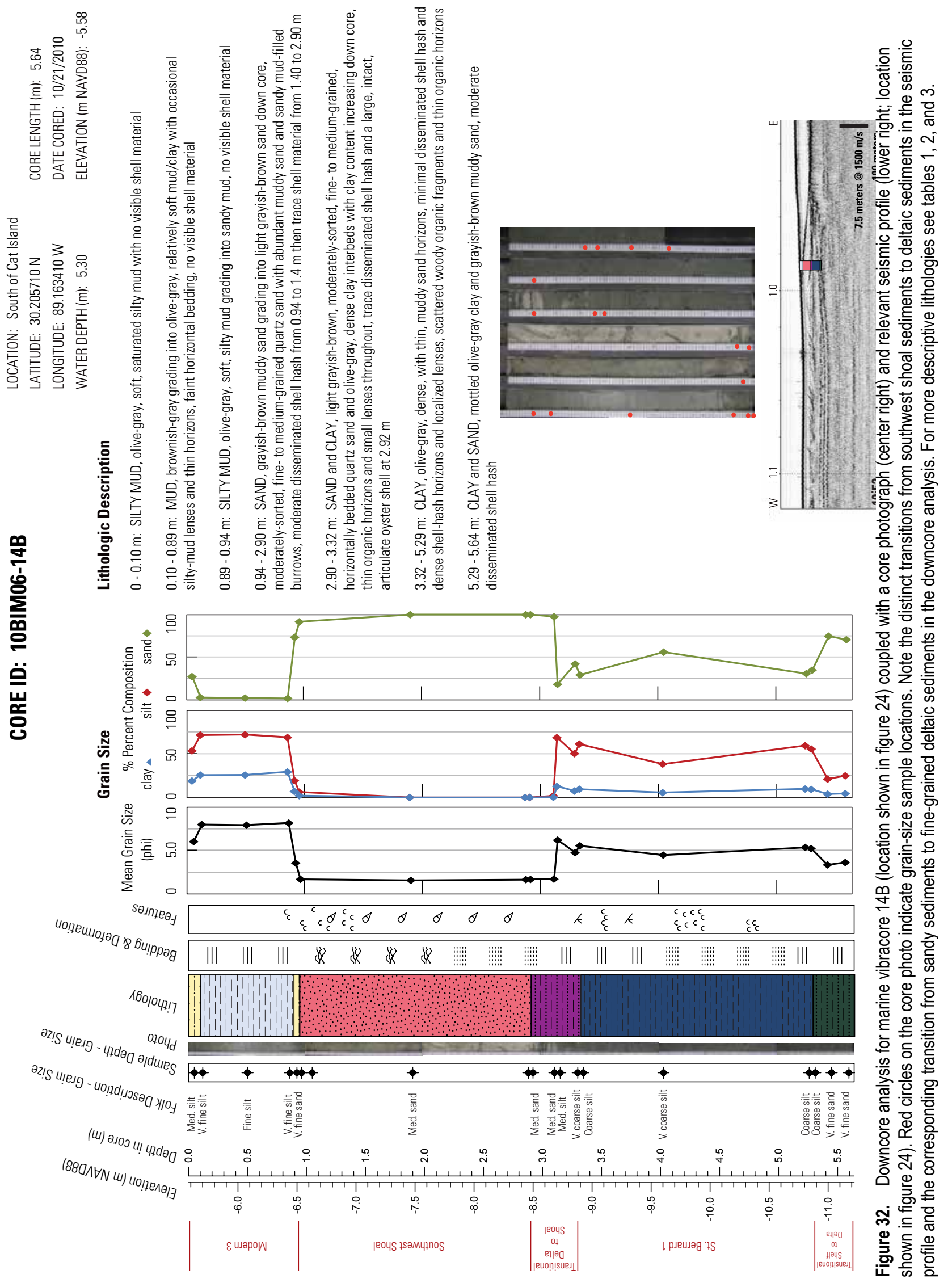



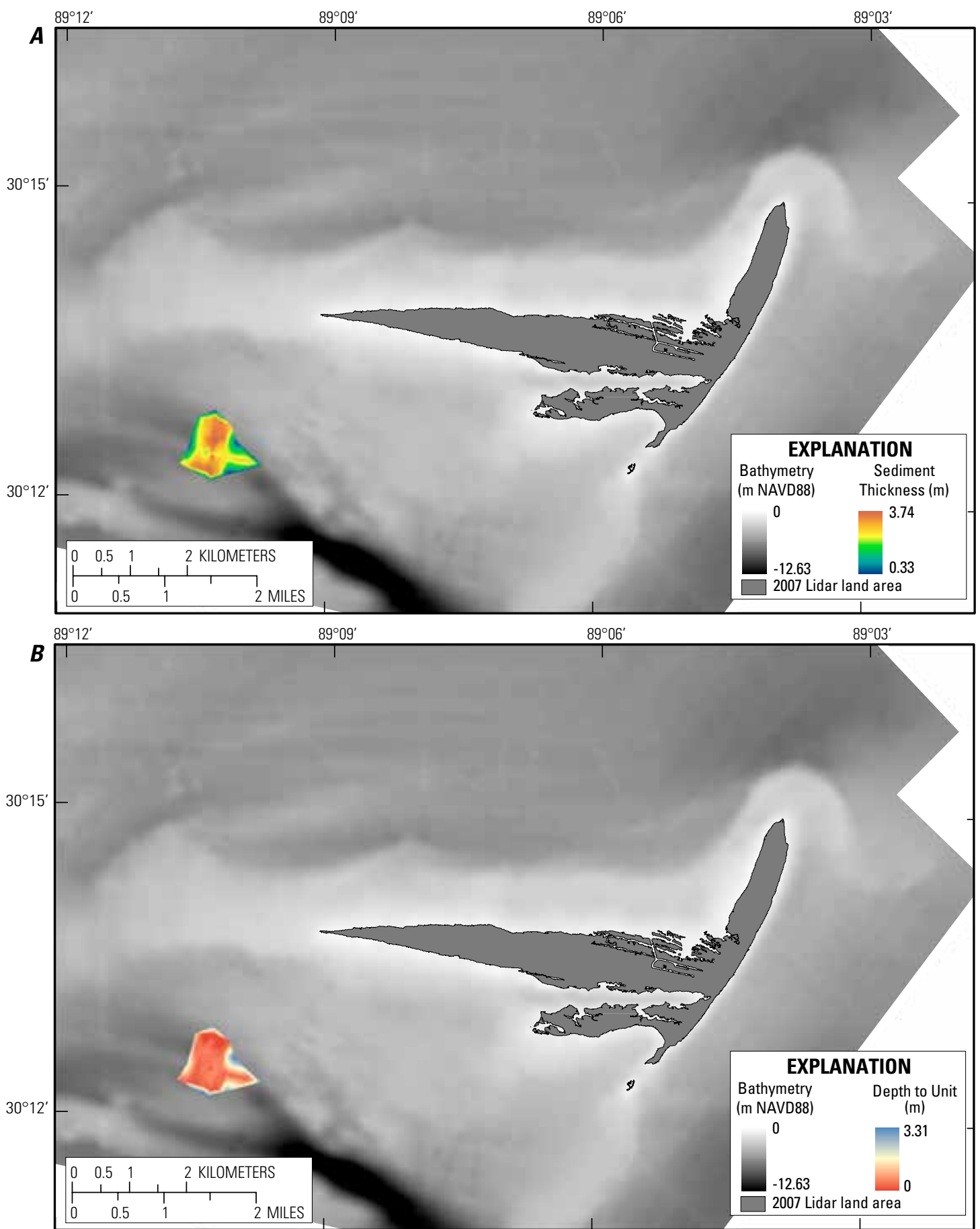

Figure 33. Maps showing (A) the extent of the southwest shoal (SWS) unit and unit thickness and (B) the depth to the top of the unit. Though reaching a maximum thickness of almost 4 meters, the unit is relatively discrete. The top of the unit generally intersects the seafloor, except where it pinches out at its limits. 


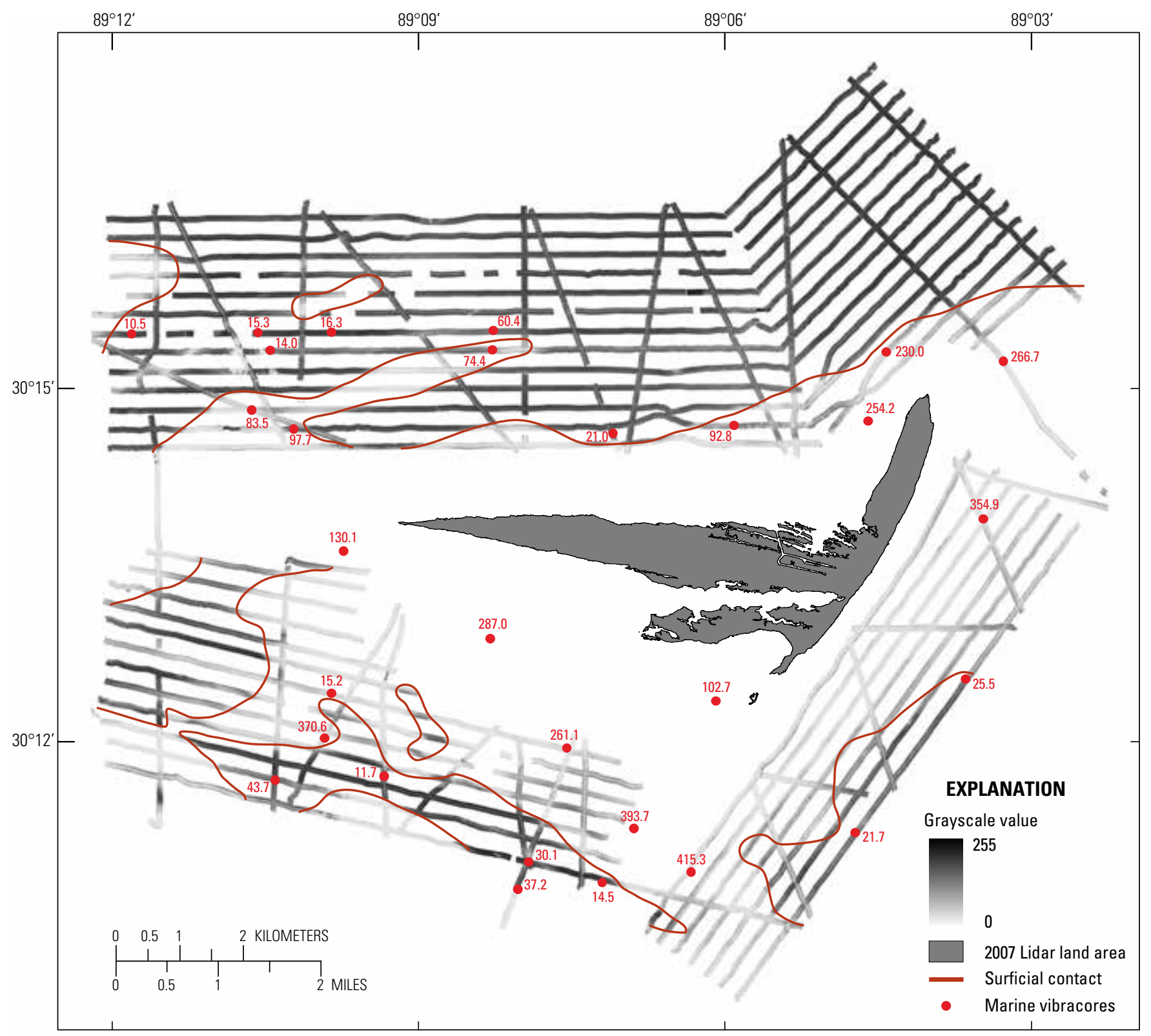

Figure 34. Map of acoustic backscatter from around Cat Island overlain with the grain size, in micrometers $(\mu \mathrm{m})$, of the surface sediment from all marine vibracores. The red line indicates a transition from higher backscatter (lighter color, larger grain sizes) to lower backscatter (darker color, smaller grain sizes). Note that the Cat Island Channel (location shown in figure 8) shows lower backscatter and smaller grain sizes, consistent with its incision into finer grained, relict sediments. 


\section{Geologic and Sedimentologic History East of Cat Island}

Unlike the south side of Cat Island, where the AIP and SBDL deposits are covered by modern or reworked sediment, relict sediments east of the island are exposed at the seafloor. The backscatter mosaic for the east side confirms the exposure (fig. 34), showing a transition from sandy sediments at the seafloor to the north (lighter colors) to finer grained sediments at the seafloor to the south (darker colors). The transition in backscatter intensity in the mosaic corresponds to a transition from ravined AIP to SBDL deposits in the seismic profiles.

Because the eastern end of Cat Island has transformed, giving the island its distinct shape (see Coastal Setting and Regional Geology section for description), the stratigraphic record east of Cat Island is the least complete when compared to its northern and southern counterparts. Acoustic penetration into the subsurface also decreased significantly because of persistent gas presence in the sediments south of the area and increased signal attenuation in the sediments toward the north. Regardless, the geology and sedimentology to the east of the island are important because they provide insight into the intersection of processes that influenced the late Holocene evolution of Cat Island.

Seismic profiles 44 and 44a located east of Cat Island, clearly show what we interpret to be the end of the AIP, slightly south of the southern extent of Middle Spit (figs. 35 and 36). Where the old platform meets units to the south, the island platform's internal structure is characterized by steep clinoforms. North of the platform edge, the island-platform unit is almost acoustically transparent, often indicative of homogeneous sandy sediments. However, in several seismic profiles there are discrete, chaotic, discontinuous reflections present (fig. 36).

The lithologic characteristics of the AIP unit in the eastern area were determined from Core 3 (fig. 36); the core description is shown in figure 37. The sediment is predominantly fine- to mediumgrained sand, with a mud content generally less than 5 percent. There is a $1-\mathrm{m}(3.28 \mathrm{ft})$ thick layer, approximately $3 \mathrm{~m}(\sim 9.8 \mathrm{ft})$ below the seafloor, in which bedding alternates between sand and mud (fig. 37). Because terrestrial cores were collected on the island (Buster and others, 2014), we compared a photo of one terrestrial core with the core sample from the AIP unit (figs. 35 and 38). Given the similarity between the two cores, it seems likely that the unit exposed at the seafloor northeast of the modern island is the ravined AIP unit, the destruction of which likely supplied sand for development of the $\mathrm{N}-\mathrm{S}$ spit that serves as the eastern shoreline of the island. Connecting the extent of the AIP, as observed in the data from the north, south, and east of the modern island, begins to show what the shape and orientation of the island might have been as the SBDL built into the northern Gulf of Mexico (fig. 31).

South of the AIP edge, the acoustic signature of the sediment changes drastically (fig. 36). The seismic profile shows a horizontally laminated unit below an almost acoustically transparent unit, similar to the characteristics of the interpreted SBDL deposits (SB1 and SB2, respectively) observed on the south side of the island. Correlating delta-associated units from the south to the east side of the island was difficult using acoustic data alone because the presence of gas in the sediments masks the acoustic signature and because the shallow waters between the south and east sides of the island (crossing the submerged southern end of the N-S spit) were inaccessible. What did help confirm the correlation was a comparison of cores that sampled delta deposits from the south side with apparent delta deposits on the east side (fig. 39). The interpreted SBDL units are shown in shades of blue, the lighter blue corresponding to the acoustically transparent unit identified in the seismic profile (SB2) and the darker blue corresponding to the horizontally laminated unit below it (SB1). In cores 8 and 1, the grain size of SB2 is classified as coarse silt, and subtle compositional differences exist between each core. The lower delta deposits (SB1) are texturally similar between the south and east cores, lending more support to 


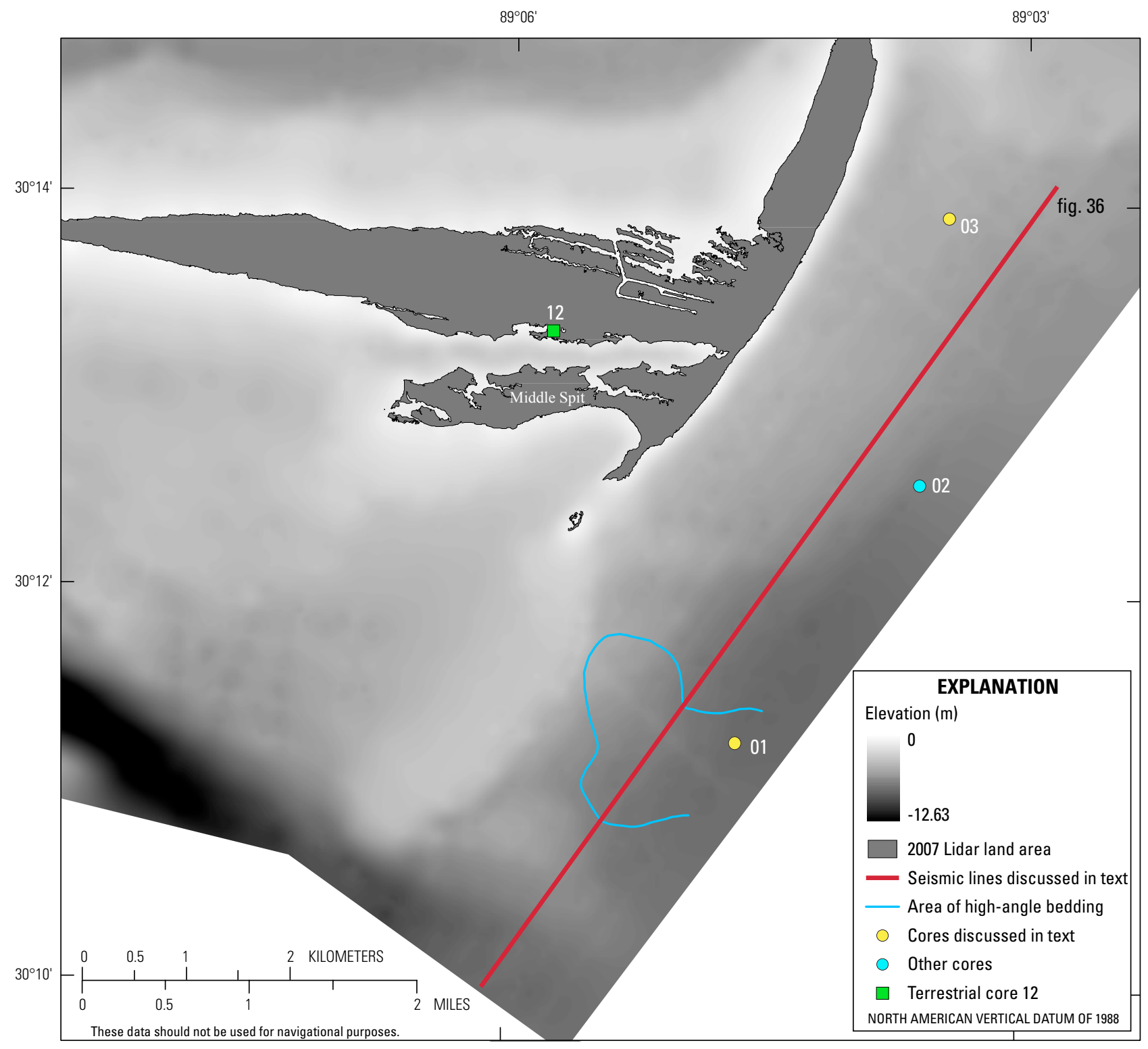

Figure 35. Map of the region east of Cat Island showing the location of seismic lines discussed in the text or in figures (red lines). Cores discussed in the text and shown in figures are represented by yellow circles. Other cores collected from this region are indicated by blue circles. Though all cores are not discussed in the text, they did contribute to interpretations, and detailed information about them can be found in Buster and others (2014). The green square represents the location of the terrestrial vibracore compared to marine core 3 in figure 38 . The blue line indicates the extent of a discrete region of anomalous reflection surfaces observed in the seismic data (fig. 36) and discussed in the text.

the interpretation (fig. 39).Upon examination of all cores where SB1 and SB2 were sampled on the east side, there is spatial variability in the size classification and composition of the SBDL deposits, similar to the south side of the island. This subtle variability is attributed to differences in the sample distance from the sediment source and in the characteristics of underlying deposits. Furthermore, the SB2 deposits east of the island (core 01) are classified as coarse silt, whereas SB2 deposits found south of the island (core 08) seem to be slightly finer (fine to medium silt). This is likely due to the fact that the eastern deposits have been ravined, winnowing finer particles. Regardless of the subtle spatial differences, the sedimentologic and acoustic signatures on the south and east sides of the island are similar enough that we can extrapolate our interpretation of delta deposits eastward. 

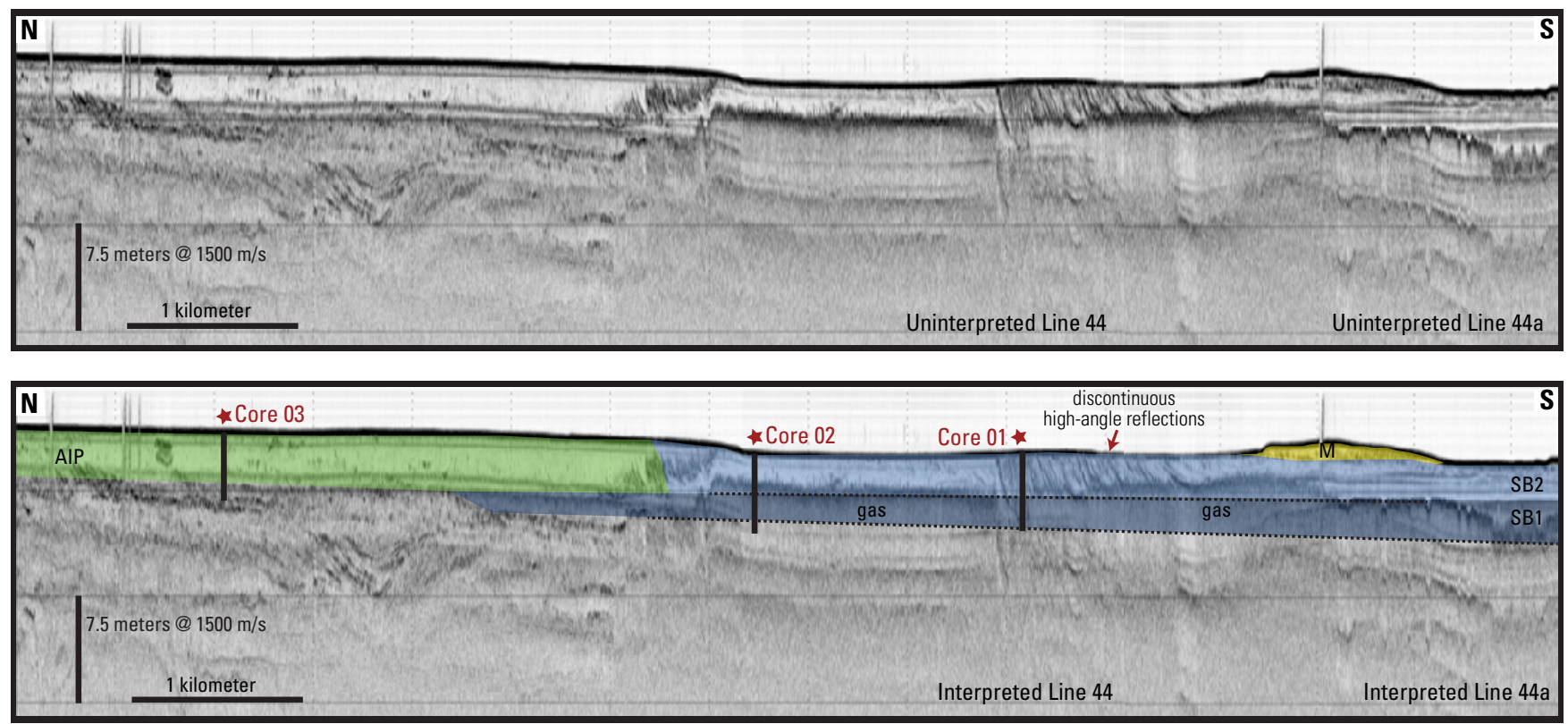

Figure 36. A non-interpreted (upper) and interpreted (lower) seismic-reflection profile from east of Cat Island that shows all units identified. The profile location is shown in figure 35. Dashed lines on the lower profile indicate interpretation through gas in the sediments, which was extensive east of the island. Although no cores shown in the profile were collected directly on this line, their locations are projected to this line via extrapolation from other seismic lines. For more descriptive lithologies see tables 1, 2, and 3.

An anomalous region was identified in the deltaic depositional units on eastern seismic profiles that was not observed in profiles from the south. On line 44, a section of the profile is characterized by steeply dipping clinoforms that truncate at the seafloor (fig. 36). The truncation indicates that what remains is only a portion of the feature that existed previously. Seismic profiles collected oblique to the shoreline that cross this unit show that the clinoforms are more gradual and dip to the southeast, implying that their geometry (apparent dip) in figure 36 is related to the survey trackline orientation relative to the feature, not to its depositional environment. The extent of the feature is fairly discrete (fig. 35), indicating that it may be related to a localized phenomenon, such as an ephemeral breach (as with a tidal channel), in a previous iteration of the island that may have incised into the delta deposits, rather than a regional process. 

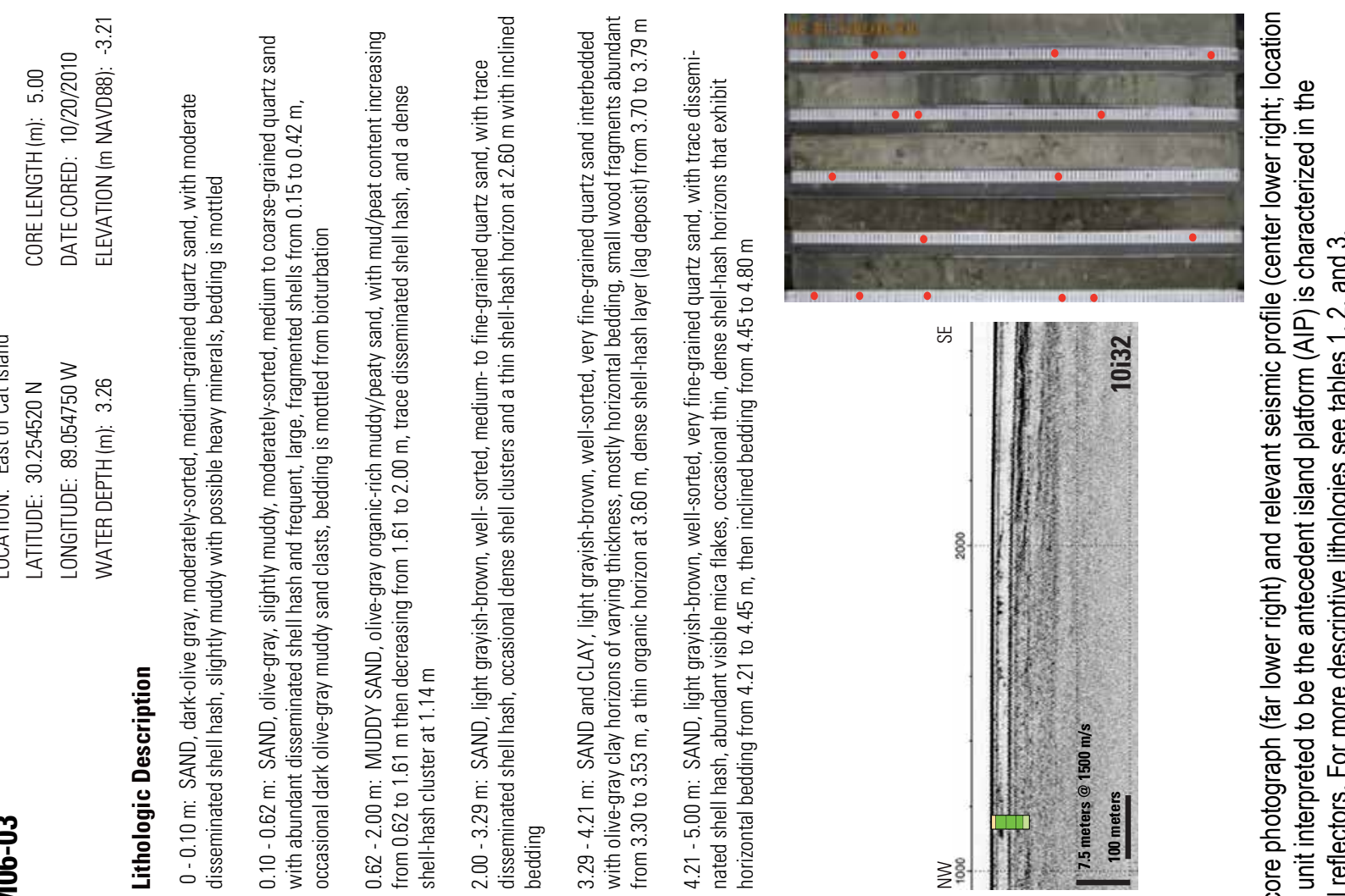

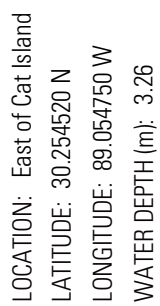

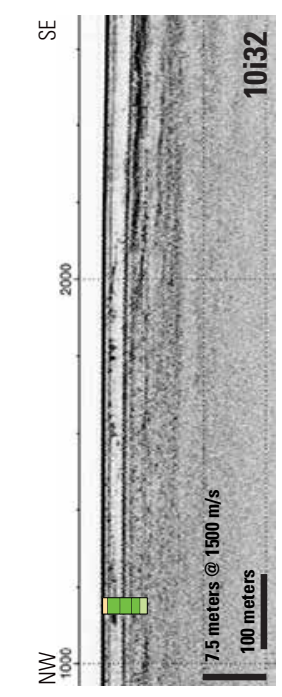

뜬 $\frac{\infty}{2}$ ㅁ

흥 क

ह 틍 음

क 웡

든을

d $\frac{\bar{\sigma}}{\underline{\omega}}$ 음

응 흥

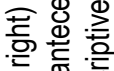

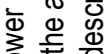

으

흉응 응

등 웡 하

흥 힌

응 호응 응

흥 言

ช

紊芯.

웡 응 음

ठํ.

돌을 엉

닌으 웅

흔 힝

들 엉

产

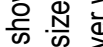

은 흔 흔

음쀼 응

๓

엏 응 정

윽 드름

든 엉

ह

능 등

क ल

तิ

屯 인

응 은

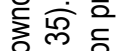

임 은

슨 은

m.

흠 兴

은 등 


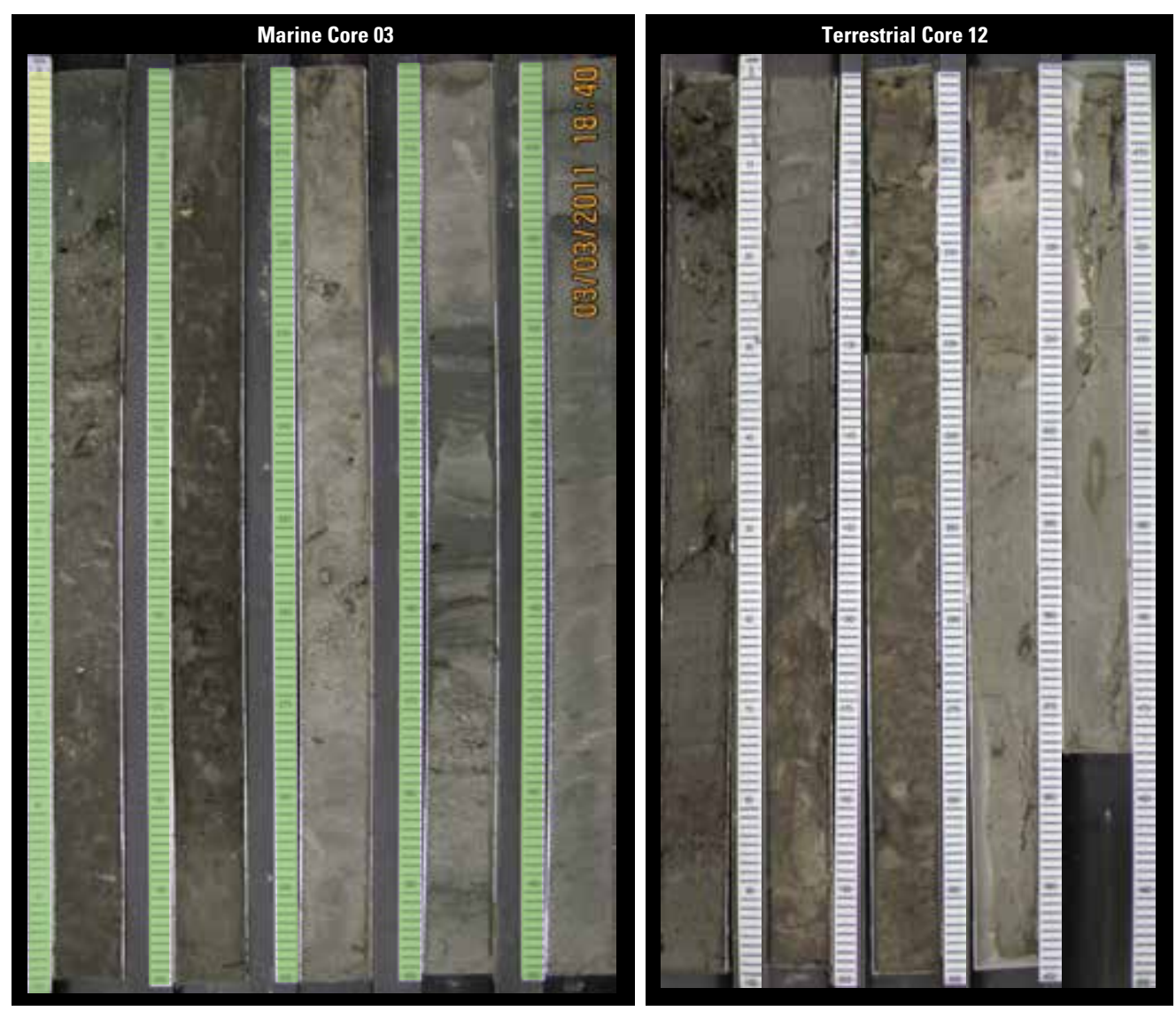

Figure 38. A comparison between a marine core collected east of Cat Island (left) with a terrestrial core collected from the youngest beach-ridge complex (right). The similarity provides further evidence that the sandy unit at the seafloor surface east of the island represents a ravined antecedent island platform. 

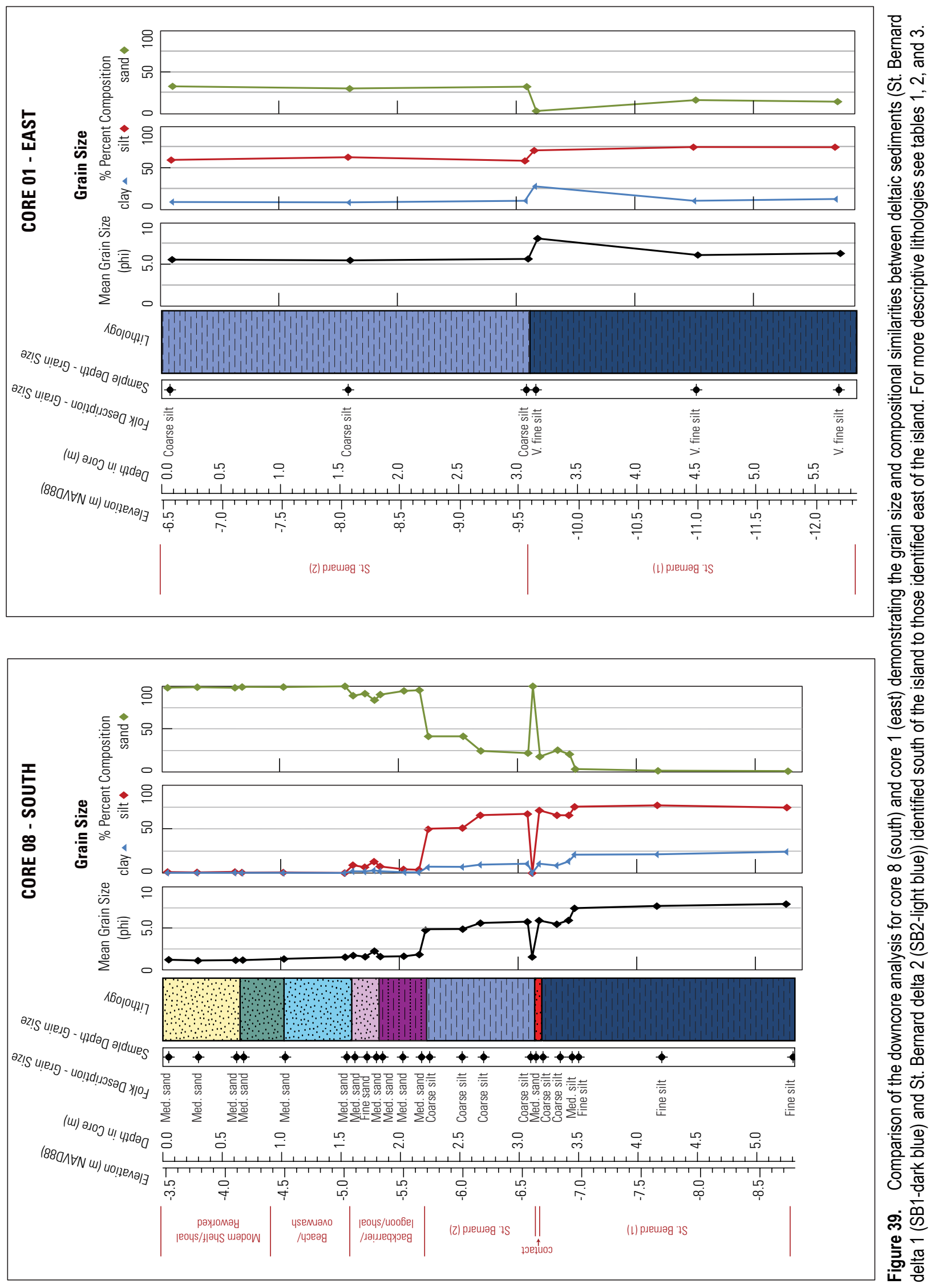


\section{Discussion}

Geophysical and sedimentological data from around Cat Island reveal that its geologic history was shaped by a combination of deltaic, tidal, lagoonal/estuarine, and oceanographic processes in addition to relative sea-level rise. Information about past sea-level fluctuations is not apparent from our data, with the exception of the lowstand associated with the last glacial maximum. During the most recent low sea level period, the MS-AL continental shelf was subaerially exposed, allowing streams and rivers to incise the shelf (Kindinger, 1988, 1989; Winn and others, 1998). Despite the varied success of acoustic penetration across the survey area, this lowstand surface is visible in some seismic profiles (figs. 13 and 14). Given the geographic location of the study area, it is likely that observed incisions are related to the ancestral Pearl River and its minor tributaries (Kindinger, 1988, 1989). During the subsequent rise in sea level, the incised channels were infilled, typically with poorly sorted, coarse-grained to silty fine sand. As sea level continued to rise, the filled channels may have been ravined and capped by a coarser transgressive lag. Though not observed in every seismic line collected around Cat Island, the data show a regionally identifiable ravinement surface (fig. 14), indicative of the influence of sea-level rise in the island's geologic history.

Stratigraphic units comprised of deltaic deposits have been identified south and east of Cat Island and are related to the growth of the Mississippi River Delta (Miselis and others, 2013). The SBDL, one of many lobes associated with the Mississippi River Delta, is the only delta lobe thought to have encroached into this area of the northern Gulf of Mexico (Fisk, 1952; Frazier, 1967; Penland and others, 1985; Roberts, 1997). The relation between the SBDL and the Chandeleur Islands in southeastern Louisiana (fig. 1) is well documented (Penland and others, 1985; Twichell and others, 2009). Otvos and Giardino (2004) suggested that SBDL development also played a large role in the MS-AL barriers formation, especially at the western end of the chain, but their study did not include shallowwater geophysical data to support their speculations. Only recently have geophysical data confirmed the presence of SBDL sediments south of Ship Island (Twichell and others, 2011). The acoustic signature of delta deposits in our data is similar to that of delta deposits identified south of Ship Island and beneath the Chandeleur Islands, indicating that the fine-grained sediments that dominate the stratigraphic record south of Cat Island are SBDL deposits (Miselis and others, 2013).

Satellite imagery of the Mississippi barrier islands' modern configuration shows tidal-inletrelated shoals interspersed between the islands. It seems likely that similar features existed between the islands when the barrier-island chain started to develop 4,600 to 4,400 years ago (Otvos and Giardino, 2004) or even earlier, when a sandy platform extended from south of Mobile Bay to southeastern Louisiana (Otvos, 1981; Otvos and Giardino, 2004). Data from north and south of the island indicate a similar configuration existed in the past. In the south, a sandy unit, in some places less than $1.5 \mathrm{~m}$ (4.9 ft) below the seafloor, was interpreted as a tidal delta (fig. 28, SWTD). The morphology and thickness of the SWTD suggest it is an ebb-tidal shoal that formed offshore from an inlet west of Cat Island. The precise origin of the sandy units to the island's north (NUS and NLS) is less clear. Though the morphology and thickness of those units do not necessarily evoke tidal-delta deposits, their location relative to the tidal delta identified to the south indicates that the three units may have been a part of the same ebb- and flood-tide delta complex (figs. 16, 17, and 28). This seems even more likely when the AIP unit's footprint, as inferred from data north, south, and east of Cat Island, is considered (figs. 40 and 41).

Since the middle to late Holocene, lagoonal/estuarine depositional processes associated with sea-level rise and the formation of Mississippi Sound have influenced the geologic evolution north of Cat Island. The area evolved as a series of stacked stratigraphic units overlying inner-shelf deposits and the ravinement surface, respectively (fig. 12). High-energy conditions are represented by high-angle 


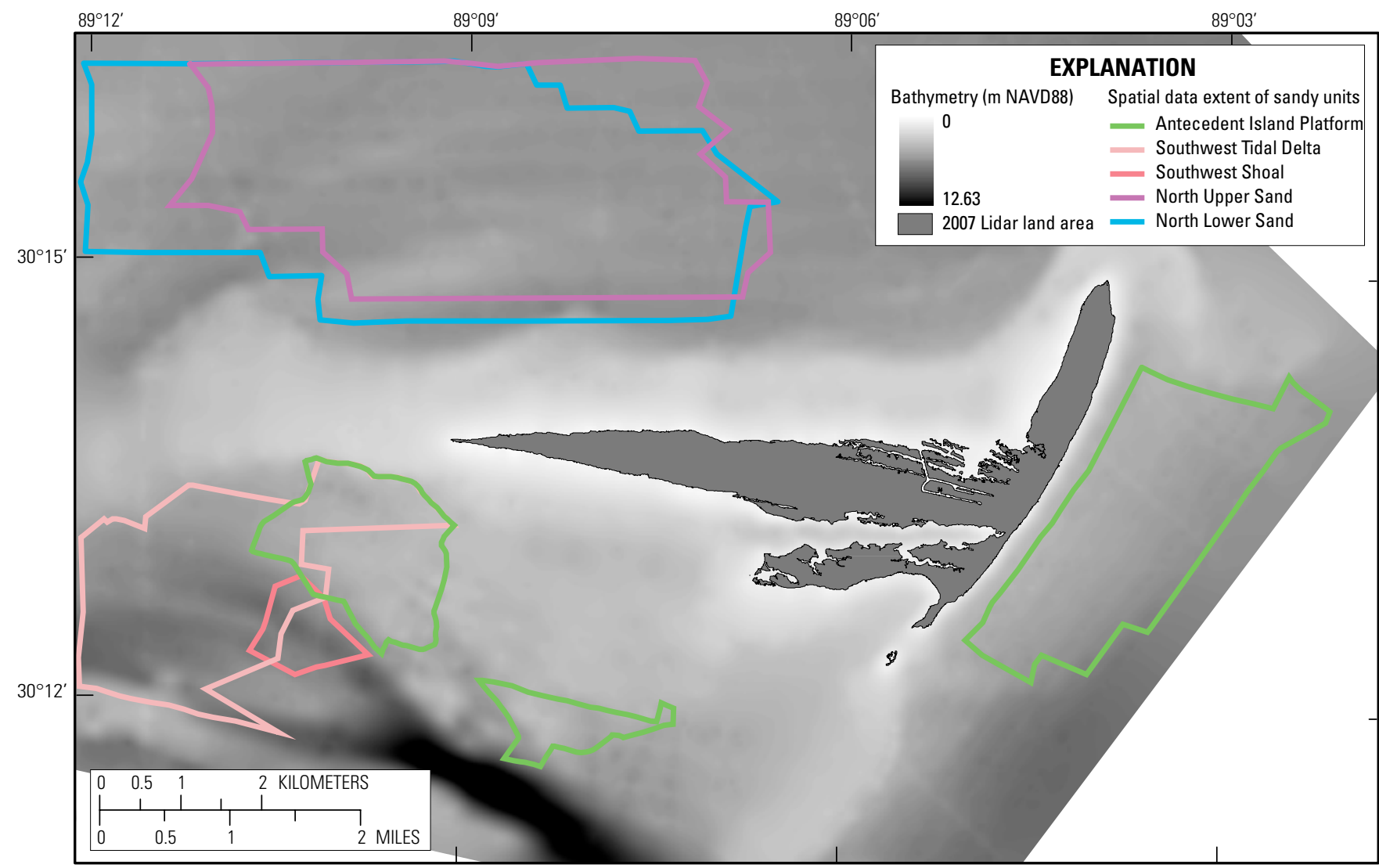

Figure 40. Map of the sand units' extent identified in this study. Line colors correspond to unit colors in table 1. For area, volumes, thicknesses, and depths to units, see table 4 . The shapes of the units outlined are not necessarily representative of the actual morphology of the deposits due to data-coverage limitations.

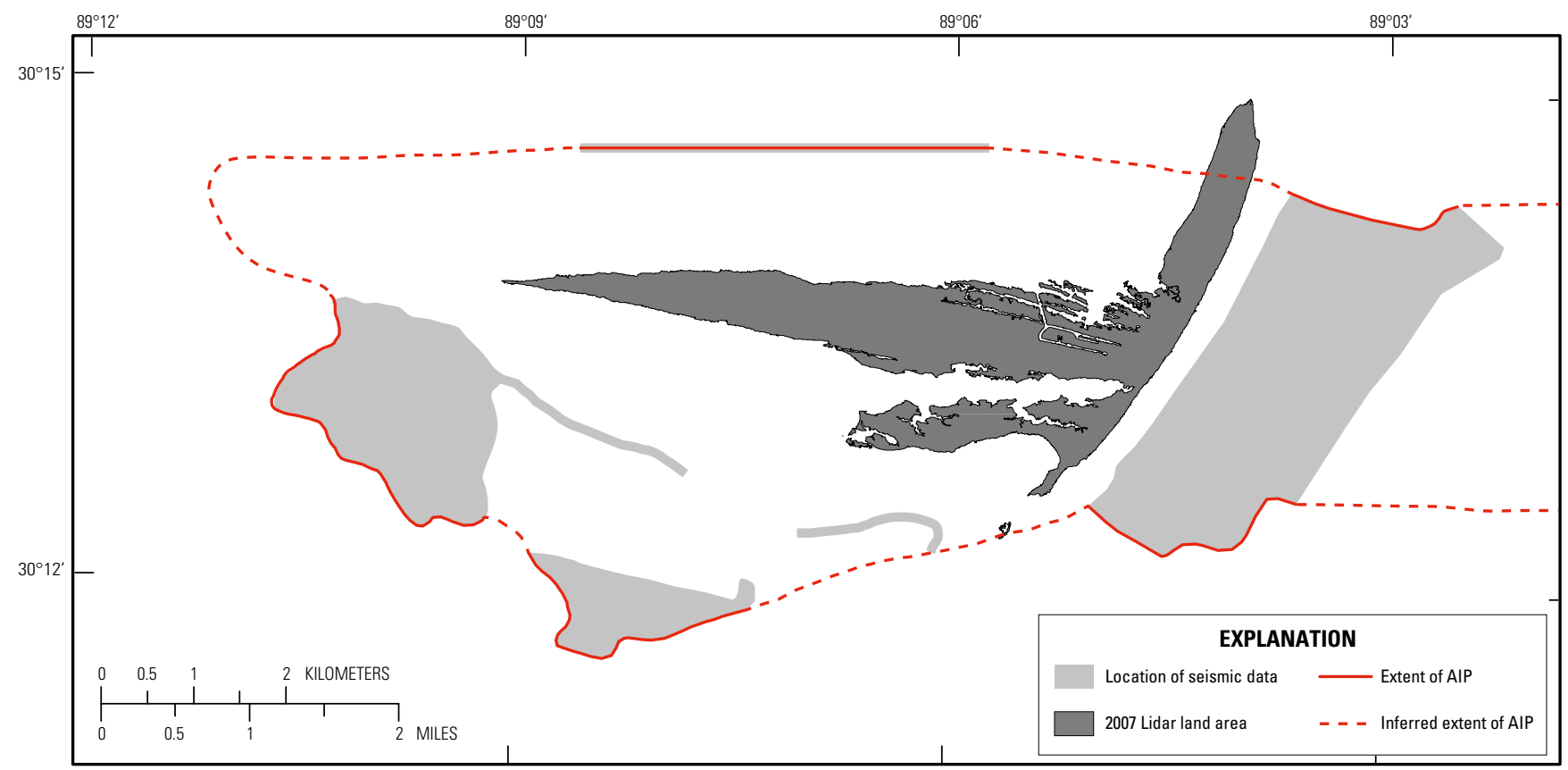

Figure 41. Map depicting the interpreted extent of the antecedent island-platform unit north, south, and east of Cat Island. Gray polygons indicate the source locations of seismic data that support this interpretation. The solid line indicates the extent of the antecedent island platform (AIP) as indicated by the data. The dashed line indicates the inferred extent of the AIP. 
clinoforms with high-amplitude seismic facies, such as those associated with beaches, overwash, inlets, and beach ridges. Given the angle of the clinoforms, our results indicate that the NLS unit was deposited in shallow water under energetic conditions. However, in some places within the unit, high-angle clinoforms seem to dip in opposite directions (fig. 13), which may be typical of the low-lying barrier islands in the northern Gulf of Mexico that are battered on their northern shorelines during seasonal storms and on their southern shorelines during tropical storms (Stone and others, 2004). Further investigation into this observation may be warranted.

As sea level rose and water depth increased, less-energetic conditions ensued. The NUS unit exemplifies this energy decrease with its low-angle horizons and lower amplitude seismic signatures (fig. 19). The sandy character of the unit indicates that back-barrier sand-transport processes such as moderate overwash, shoal/bar migration, or flood-tide delta development dominated over less-energetic lagoonal/estuarine depositional processes (fig. 20).

The modern lagoonal/estuarine deposits of Mississippi Sound represent the least-energetic conditions north-northeast of Cat Island. Water depth increased to protect the seafloor from wave activity generated by all but major seasonal and extreme storms. The seismic facies of these lagoonal/estuarine units are characterized by interior, discontinuous, low-amplitude horizontal horizons with areas that are acoustically transparent (figs. 14 and 23). The fine-grained lithology observed in these units is consistent with modern, low-energy Mississippi Sound sediments.

The influence of changing oceanographic conditions on the evolution of Cat Island is best demonstrated on the island's east side. Our results support the existence of a much more E-W linear footprint for Cat Island, before the development of the SBDL, as suggested by previous studies (Rucker and Snowden, 1989; Otvos and Giardino, 2004). In figure 41, we present our interpretation of what the island footprint may have looked like as the SBDL began to influence oceanographic conditions around the island. Bathymetry data show no suggestion of this feature east of the island (fig. 10). However, the seismic data reveal ravined stratigraphic units in its place. A comparison of a marine vibracore collected from within the AIP footprint bears a striking resemblance to a terrestrial core collected from the youngest beach-ridge complex on the island (fig. 38). As the SBDL prograded into the northern Gulf of Mexico, Cat Island became more and more sheltered from waves propagating from the south or southeast; additionally, growth of the delta may have limited the sand supply from the east (Morton, 2008). This combination of changing oceanographic processes and sediment supply caused a transformation of the Cat Island platform from its more E-W linear shape to the distinct "T" shape it has today. As conditions changed, waves and currents reworked the AIP sediments at the east end of the island and transported them north and south to create the dynamic N-S spit that serves as the island's eastern shoreline. Given the lack of sand supplied from the barriers east of Cat Island (Morton, 2008; Byrnes and Berlinghoff, 2012; Walstra and others, 2012) and the fact that these relict sediments supplied sand to the island over geologic time, it is reasonable to hypothesize that continued ravinement of this unit may be the only source of sand to Cat Island in the future, however inadequate it might be.

Despite the variety of influences on the geologic evolution of Cat Island, the stratigraphic record around the island is dominated by fine-grained sediment. We have identified four sandy units that could be considered suitable sand resources for coastal restoration (fig. 40). Suitable sand resources are defined here as (1) surficial deposits with greater than 60 percent sand and thicknesses greater than $2 \mathrm{~m}$ $(6.6 \mathrm{ft})$ or $(2)$ buried deposits that are $<18.3 \mathrm{~m}(<60 \mathrm{ft})$ below sea level, have $<2 \mathrm{~m}(<6.6 \mathrm{ft})$ of over-

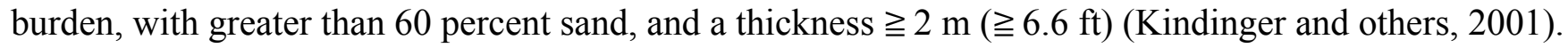
The first and most extensive is the AIP unit, which is greater than 95 percent sand and approximately $5 \mathrm{~m}$ (16.4 ft) thick at its maximum. The AIP unit was identified in seismic profiles north, south, and 
east of the island (figs. 31, 40, and 42). This unit represents the footprint of Cat Island before the island was transformed by changing oceanographic conditions that resulted from delta growth. This unit is, on average, less than $2 \mathrm{~m}(6.6 \mathrm{ft})$ below the seafloor on the south side of the island and at the seafloor east of the island (fig. $31 \mathrm{~B}$ ). Over geologic and historic timescales, our data and previous work indicate that this unit has been a sand source for Cat Island (Rucker and Snowden, 1989; Otvos and Giardino, 2004). The observed exposure at the seafloor east of the island, coupled with the predominance of westwarddirected longshore transport, indicates that this unit may be part of a modern littoral transport. As it may be the only current sediment supply to the island, it is necessary to further explore the role of the AIP in Cat Island's sediment budget. This would require analysis of repetitive beach and nearshore surveys and an incident wave climate assessment.

The other three units identified are all toward the western edge of the study area and not exposed at the seafloor. It is unlikely they play a role in Cat Island's modern littoral sand budget, which makes them more suitable resources for coastal restoration. Two of the sand units are northwest of the island and one overlies the other (NUS and NLS). On average, the upper unit is $\sim 2 \mathrm{~m}(6.6 \mathrm{ft})$ below the seafloor, $>90$ percent sand, and a little over $3 \mathrm{~m}$ (9.8 ft) in thickness (fig. 17, table 4). Despite meeting the criteria for sand content and thickness for suitable resources, like the upper unit, the lower unit is farther below the seafloor ( 4 m; 13 ft) (fig. 16). Both units are extensive and because they often appear to be stacked in the seismic profiles, in combination the deposits represent a significant volume $(\sim 100 \mathrm{M}$ $\left.\mathrm{m}^{3} ; \sim 130.8 \mathrm{M} \mathrm{yd}^{3}\right)$. The final unit lies to the southwest of Cat Island and has been interpreted to be a tidal-delta deposit (SWTD). It meets the suitable-resource criteria with $>95$ percent sand and an average thickness of $>3 \mathrm{~m}(>9.8 \mathrm{ft}$ ) (figs. 28, 30, table 4). Data coverage was limited to the west, so the true volume is expected to exceed estimates from this study $\left(25.2 \mathrm{M} \mathrm{m}^{3} ; 32.96 \mathrm{M} \mathrm{yd}^{3}\right)$. The unit also thickens to the west and rises toward the seafloor, so even though the average depth to the unit is almost $4 \mathrm{~m}$ $(\sim 13 \mathrm{ft})$, on the western edge it decreases to a minimum of $\sim 1.4 \mathrm{~m}(\sim 4.6 \mathrm{ft})$ below the seafloor (table 4$)$. Expanding data coverage to the west will provide a better picture of the feature's morphology and enable a more refined sand volume estimate.

\section{Conclusions}

Geophysical and sedimentological data collected from around Cat Island, Mississippi, have elucidated the complex stratigraphy that surrounds the island. The complexity relates to the many influences on the geologic evolution of the island, such as fluvial, deltaic, lagoonal/estuarine, tidal, and oceanographic processes that occurred as sea level rose during the Holocene. A ravinement surface mapped throughout the study area provides regional evidence of sea-level rise and fluvial processes. The interplay between sea-level rise and lagoonal/estuarine depositional processes was found on the island's northern side. Strata on the south side are dominated by deltaic sediments deposited during the progradation of the SBDL into the northern Gulf of Mexico, but also show the influence of tidal processes that existed west of the modern island. The island's eastern side has the least complete geologic record due to oceanographic processes that ravined relict deposits, transforming the east end of Cat Island into its modern shape. While the study area around Cat Island is not rich in sandy deposits, three suitable sandy stratigraphic units were identified in the western portion of the study area. These resources are probably not involved in present littoral transport and, with further investigation, may serve as suitable sand resources for regional coastal-restoration projects. 

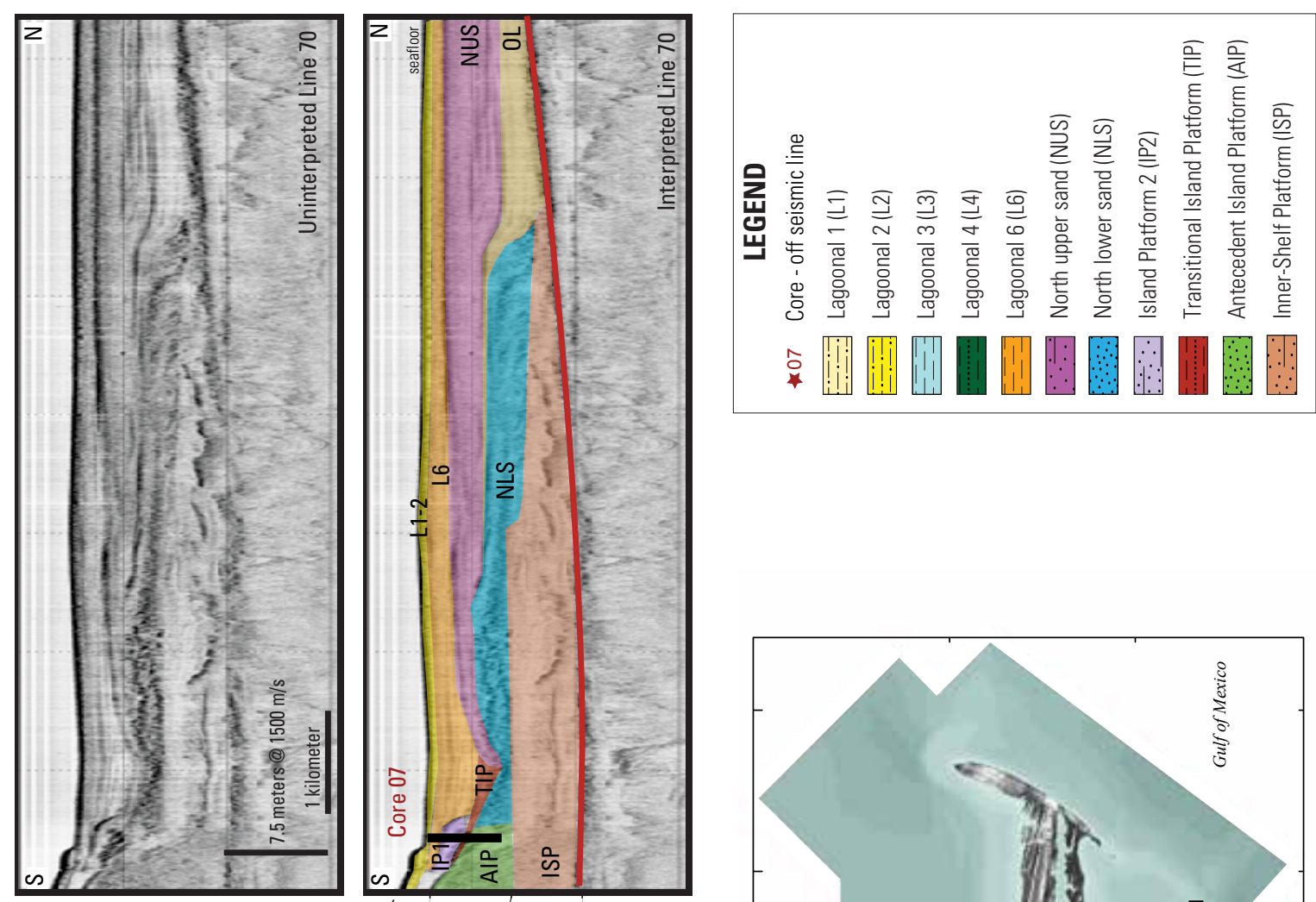

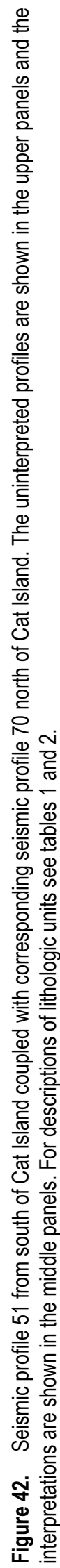
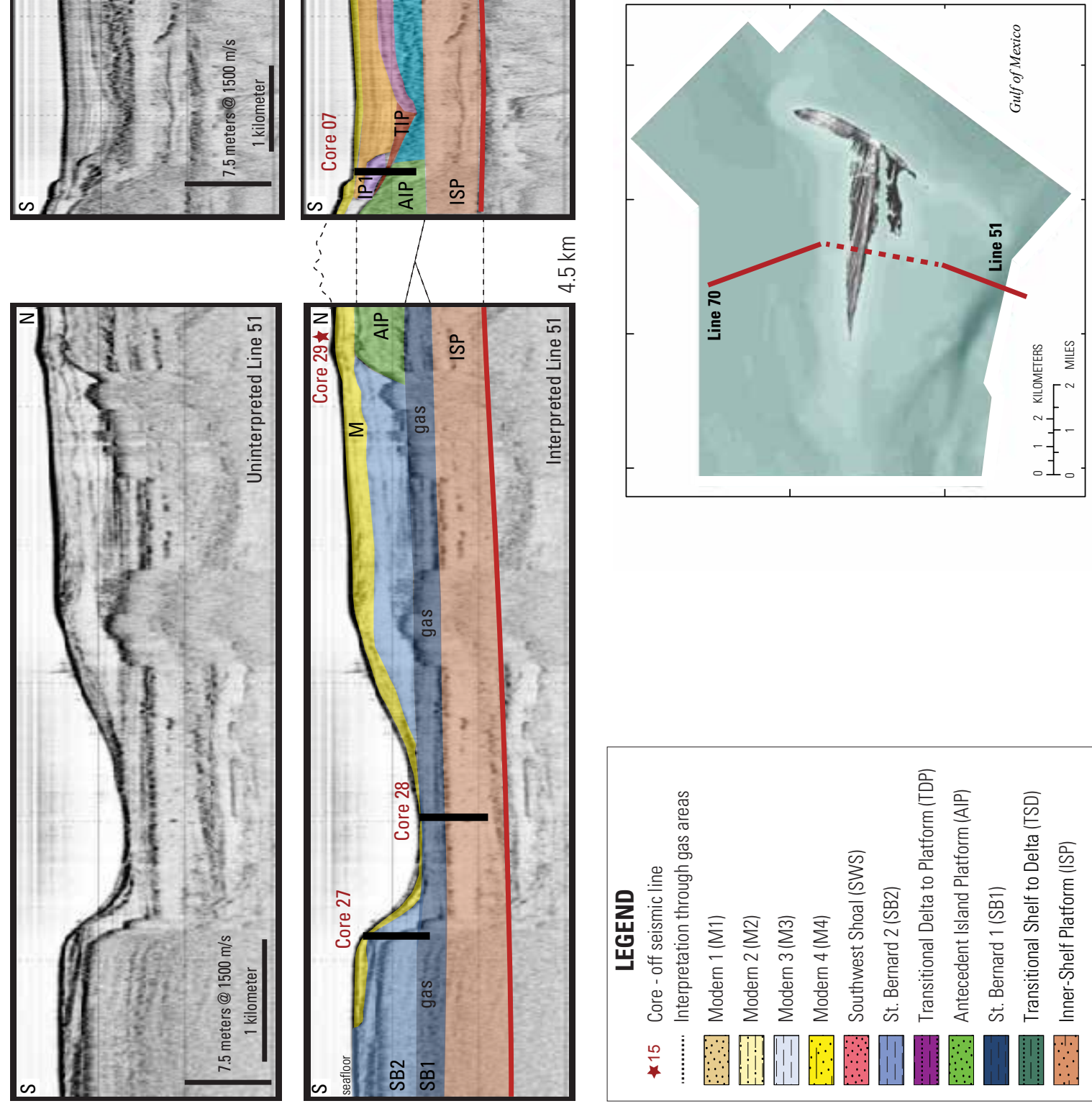


\section{References}

Barry, K.M., Cavers, D.A., and Kneale, C.W., 1975, Recommended standards for digital tape formats: Geophysics, v. 40, no. 2, p. 344-352. [Also available at $\mathrm{http}: / / d x$.doi.org/10.1190/1.1440530.]

Blott, S.J., and Pye, Kenneth, 2001, GRADISTAT - A grain size distribution and statistics package for the analysis of unconsolidated sediments: Earth Surface Processes and Landforms, v. 26, no. 11, p. 1237-1248. [Also available at $\mathrm{http}: / / d x$.doi.org/10.1002/esp.261.]

Buster, N.A., Pfeiffer, W.R., Miselis, J.L., Kindinger, J.L., Wiese, D.S., and Reynolds, B.J., 2012, Bathymetry and acoustic backscatter data collected in 2010 from Cat Island, Mississippi: U.S. Geological Survey Data Series Report 739, 1 DVD, accessed March, 17, 2014, at http://pubs.usgs. gov/ds/739/.

Buster, N.A., Kelso, K.W., Miselis, J.L., Kindinger, J.L., 2014, Sediment data collected in 2010 from Cat Island, Mississippi: U.S. Geological Survey Data Series Report 834. [Also available at http://dx.doi.org/10.3133/ds834.]

Byrnes, M.R., and Berlinghoff, J.L., 2012, Gulf regional sediment management master plan-Case study compilation: Journal of Coastal Research, Special Issue no. 60, p. 72-124.

Byrnes, M.R., McBride, R.A., Penland, P.S., Hiland, M.W., and Westphal, K.A., 1991, Historical changes in shoreline position along the Mississippi Sound barrier islands in Coastal depositional systems in the Gulf of Mexico-Quaternary framework and environmental issues: Twelfth Annual Research Conference, Gulf Coast Section, Society of Economic Paleontologists and Mineralogists Foundation, Houston, Tex., 1991, p. 43-55.

Byrnes, M.R., Rosati, J.D., Griffee, S.F., and Berlinghoff, J.L., 2013, Historical sediment transport pathways and quantities for determining an operational sediment budget-Mississippi Sound barrier islands: Journal of Coastal Research, Special Issue no. 63, p. 166-183. [Also available at http://dx.doi. org/10.2112/SI63-014.1.]

Cipriani, L.E., and Stone G.W., 2001, Net longshore sediment transport and textural changes in beach sediments along the southwest Alabama and Mississippi barrier islands, U.S.A.: Journal of Coastal Research, v. 17, no. 2, p. 443-458. [Also available at http://www.jstor.org/stable/4300195.]

Fisk, H.N., 1952, Geologic investigation of the Atchafalaya Basin and the problem of Mississippi River diversion: Vicksburg, Miss., U.S. Army Corps of Engineers, Mississippi River Commission, 145 p., 3 pls., atlas of 27 folded maps.

Folk, R.L., and Ward, W.C., 1957, Brazos river bar [Texas] —A study in the significance of grain size parameters: Journal of Sedimentary Petrology, v. 27, no. 1, p. 3-26. [Also available at http://dx.doi. org/10.1306/74D70646-2B21-11D7-8648000102C1865D.]

Forde, A.S., Dadisman, S.V., Kindinger, J.L., Miselis, J.L., Wiese, D.S., and Buster, N.A., 2012, Archive of digital chirp subbottom profile data collected during USGS cruise 10BIM04 offshore Cat Island, Mississippi, September 2010: U.S. Geological Survey Data Series 724, 2 DVDs. [Also available at http://pubs.usgs.gov/ds/724/.] 
Frazier, D.E., 1967, Recent deltaic deposits of the Mississippi River-Their development and chronology: Transactions_-Gulf Coast Association of Geological Societies, v. 17, p. 287-315.

Isphording, W.C, Imsand, F.D., and Flowers, G.C., 1989, Physical characteristics and aging of Gulf Coast estuaries: Transactions_-Gulf Coast Association of Geological Societies, v. 39, p. 387-401.

Kindinger, J.L., 1988, Seismic stratigraphy of the Mississippi-Alabama shelf and upper continental slope: Marine Geology, nos. 1-4, v. 83, p. 79-94.

Kindinger, J.L., 1989, Upper Pleistocene to Recent shelf and upper slope deposits of offshore Mississippi-Alabama in Morton, R.A., and Nummedal, Dag, eds., Shelf Sedimentation, Shelf Sequences and Related Hydrocarbon Accumulation: Proceedings, 7th Annual Research Conference, Gulf Coast Section, Society of Economic Paleontologists and Mineralogists, p. 163-174.

Kindinger, J.L., Flocks, J.G., Kulp, M., Penland, S., and Britsch, L.D., 2001, Sand resources, regional geology, and coastal processes for the restoration of the Barataria Barrier shoreline: U.S. Geological Survey Open-File Report 01-384, 68 p., 5 Plates (38” x 40”), 2 CD-ROMs. [Also available at http:// pubs.usgs.gov/of/2001/0384/report.pdf.]

Knowles, S.C., and Rosati, J.D., 1989, Geomorphic and coastal process analysis for ship channel planning at Ship Island, Mississippi: Vicksburg, Miss., U.S. Army Corps of Engineers, Coastal Engineering and Research Center, Technical Report CERC-89-1, 69 p.

Krumbein, W.C., 1934, Size frequency distributions of sediments: Journal of Sedimentary Research, v. 4, no. 2, p. 65-77. [Also available at $\mathrm{http}: / / d x . d o i . o r g / 10.1306 / D 4268 E B 9-2 B 26-11 D 7-$ $\underline{8648000102 C 1865 D .]}$

McBride, R.A., and Byrnes, M.R., 1997, Regional variations in shore response along barrier island systems of the Mississippi River Delta Plain-Historical change and future prediction: Journal of Coastal Research, v. 13, no. 3, p. 628-655. [Also available at http://www.jstor.org/stable/4298660.]

McBride, R.A., Penland, P.S., Hiland, M.W., Williams, S.J., Westphal, K.A., Jaffe, B.E., and Sallenger, A.H., Jr., 1992, Analysis of barrier shoreline change in Louisiana from 1853 to 1989 in Williams, S.J., Penland, S., and Sallenger, A.H., eds., Louisiana barrier island erosion study -Atlas of shoreline changes in Louisiana from 1853 to 1989: U.S. Geological Survey Miscellaneous Investigation Series I-2150-A, p. 36-47. [Also available at http://pubs.er.usgs.gov/publication/i2150A.]

Miselis, J.L., Buster, N.A., and Kindinger, J.L., 2013, Refining the link between the Holocene development of the Mississippi River Delta and the geologic evolution of Cat Island, MS [abs]: ASLO 2013 Aquatic Sciences Meeting, New Orleans, La., Association for the Sciences of Limnology and Oceanography, accessed March 26, 2014, at https://www.sgmeet.com/aslo/neworleans2013/ viewabstract2.asp? AbstractID $=11803$.

Morton, R.A., 1988, Nearshore responses to great storms, in Clifton, H.E., ed., Sedimentologic consequences of convulsive geologic events - Geological Society of America Special Paper: Boulder, Col., Geological Society of America, v. 229, p. 7-22.

Morton, R.A., 2008, Historical changes in the Mississippi-Alabama barrier-island chain and the roles of extreme storms, sea level, and human activities: Journal of Coastal Research, v. 24, no. 6, p. 15871600. [Also available at $h t t p: / / d x$. doi.org/10.2112/07-0953.1.] 
Otvos, E.G., Jr., 1970, Development and migration of barrier islands, northern Gulf of Mexico: Geological Society of America Bulletin, v. 81, no. 1, p. 241-246. [Also available at http://dx.doi. org/10.1130/0016-7606(1970)81[241:DAMOBI]2.0.CO;2.]

Otvos, E.G., Jr., 1978, New Orleans-South Hancock Holocene barrier trends and origins of Lake Pontchartrain: Transactions_-Gulf Coast Association of Geological Societies, v. 28, p. 337-355.

Otvos, E.G., Jr., 1979, Barrier island evolution and history of migration, north central Gulf Coast, in Leatherman, S.P., ed., Barrier Islands from the Gulf of St. Lawrence to the Gulf of Mexico: New York, Academic Press, p. 291-319.

Otvos, E.G., Jr., 1981, Barrier island formation through nearshore aggradation-Stratigraphic and field evidence: Marine Geology, v. 43, nos. 3-4, p. 195-203. [Also available at http://dx.doi. org/10.1016/0025-3227(81)90181-X.]

Otvos, E.G., 1985, Barrier island genesis-Questions of alternatives for the Apalachicola coast, northeastern Gulf of Mexico: Journal of Coastal Research, v. 1, no. 3, p. 267-278. [Also available at http://www.jstor.org/stable/4297065.]

Otvos, E.G., 1986, Island evolution and "stepwise retreat"-Late Holocene transgressive barriers, Mississippi delta coast-Limitations of a model: Marine Geology, v. 72, nos. 3-4, p. 325-340. [Also available at $\underline{h t p: / / d x . d o i . o r g / 10.1016 / 0025-3227(86) 90126-X}$.]

Otvos, E.G., and Carter, G.A., 2008, Hurricane degradation-barrier development cycles, northeastern Gulf of Mexico - Landform evolution and island chain history: Journal of Coastal Research, v. 24, no. 2, p. 463-478. [Also available at http://dx.doi.org/10.2112/06-0820.1.]

Otvos, E.G., and Giardino, M.J., 2004, Interlinked barrier chain and delta lobe development, northern Gulf of Mexico: Sedimentary Geology, v. 169, nos. 1-2, p. 47-73. [Also available at http://dx.doi. org/10.1016/j.sedgeo.2004.04.008.]

Penland, P.S., Suter, J.R., and Boyd, R., 1985, Barrier island arcs along abandoned Mississippi River deltas: Marine Geology, v. 63, nos. 1-4, p. 197-233. [Also available at $h t t p: / / d x . d o i$. org/10.1016/0025-3227(85)90084-2.]

Roberts, H.H., 1997, Dynamic changes of the Holocene Mississippi River Delta Plain-The delta cycle: Journal of Coastal Research, v. 13, no. 3, p. 605-627. [Also available at http://www.jstor.org/ stable/4298659.]

Rose, K.V.G., 2010, Configuration of the Pleistocene surface beneath Cat Island, Mississippi, and nearshore-Implications for barrier island formation and evolution: University of New Orleans Master's Thesis (M.S.), 94 p.

Rucker, J.B., and Snowden, J.O., 1989, Relict progradational beach ridge complex on Cat Island in Mississippi Sound: Transactions_-Gulf Coast Association of Geological Societies, v. 39, p. 531-539.

Saucier, R.T., 1963, Recent geomorphic history of the Pontchartrain Basin: Louisiana State University Studies, Coastal Studies Series, v. 9, 114 p. 
Smith, K.E.L., Nayegandhi, Amar, Wright, C.W., Bonisteel, J.M., and Brock, J.C., 2009, EAARL coastal topography-Northern Gulf of Mexico, 2007-Bare Earth: U.S. Geological Survey Data Series 400, accessed March, 21, 2014, at http://pubs.usgs.gov/ds/400/.

Stone, G.W., Liu, Baozhu, Pepper, D.A., and Wang, Ping, 2004, The importance of extratropical and tropical cyclones on the short-term evolution of barrier islands along the northern Gulf of Mexico, USA: Marine Geology, v. 210, nos. 1-4, p. 63-78. [Also available at $h t t p: / / d x . d o i . o r g / 10.1016 / j$. margeo.2004.05.021.]

Twichell, D.C., Pendleton, E.A., Baldwin, W.E., and Flocks, J.G., 2009, Subsurface control on seafloor erosional processes offshore of the Chandeleur Islands, Louisiana: Geo-Marine Letters, v. 29, no. 6, p. 349-358. [Also available at $\mathrm{http}: / / d x$.doi.org/10.1007/s00367-009-0150-x.]

Twichell, D.C., Pendleton, E.A., Baldwin, W.E., Foster, D.S., Flocks, J.G., Kelso, K.W., DeWitt, N.T., Pfeiffer, W.R., Forde, A.S., Krick, Jason, and Baehr, John, 2011, The shallow stratigraphy and sand resources offshore of the Mississippi barrier islands: U.S. Geological Survey Open-File Report 20111173, accessed March, 21, 2014, at http://pubs.usgs.gov/of/2011/1173.

Walstra, D.J.R., De Vroeg, J.H., Van Thiel De Vries, J.S.M., Swinkels, C., Luijendijk, A.P., De Boer, W.P., Hoekstra, R., Hoonhout, B., Henrotte, J., Smolders, T., Dekker, F., and Godsey, E., 2012, A comprehensive sediment budget for the Mississippi barrier islands: Proceedings, 33rd International Conference on Coastal Engineering (ICCE) 2012, Santander, Spain, 15 p.

Wamsley, T.V., Godsey, E.S., Bunch, B.W., Chapman, R.S., Gravens, M.B., Grzegorzewski, A.S., Johnson, B.D., King, D.B., Permenter, R.L., Tillman, D.H., and Tubman, M.W., 2013, Mississippi Coastal Improvements Program-Evaluation of barrier island restoration efforts: Vicksburg, Miss., U.S. Army Engineer Research and Development Center, ERDC TR-13-12, 489p.

Wentworth, C.K., 1922, A scale of grade and class terms for clastic sediments: Journal of Geology, v. 30, no. 5, p. 377-392. [Also available at http://www.jstor.org/stable/30063207.]

Winn, R.D., Jr., Roberts, H.H., Kohl, B., Fillon, R.H., Crux, J.A., Bouma, A.H., and Spero, H.W., 1998, Upper Quaternary strata of the upper continental slope, northeast Gulf Of Mexico-Sequence stratigraphic model for a terrigenous shelf edge: Journal of Sedimentary Research, v. 68, no. 4, p. 579-595. [Also available at http://dx.doi.org/10.2110/jsr.68.579.] 
Appendix 

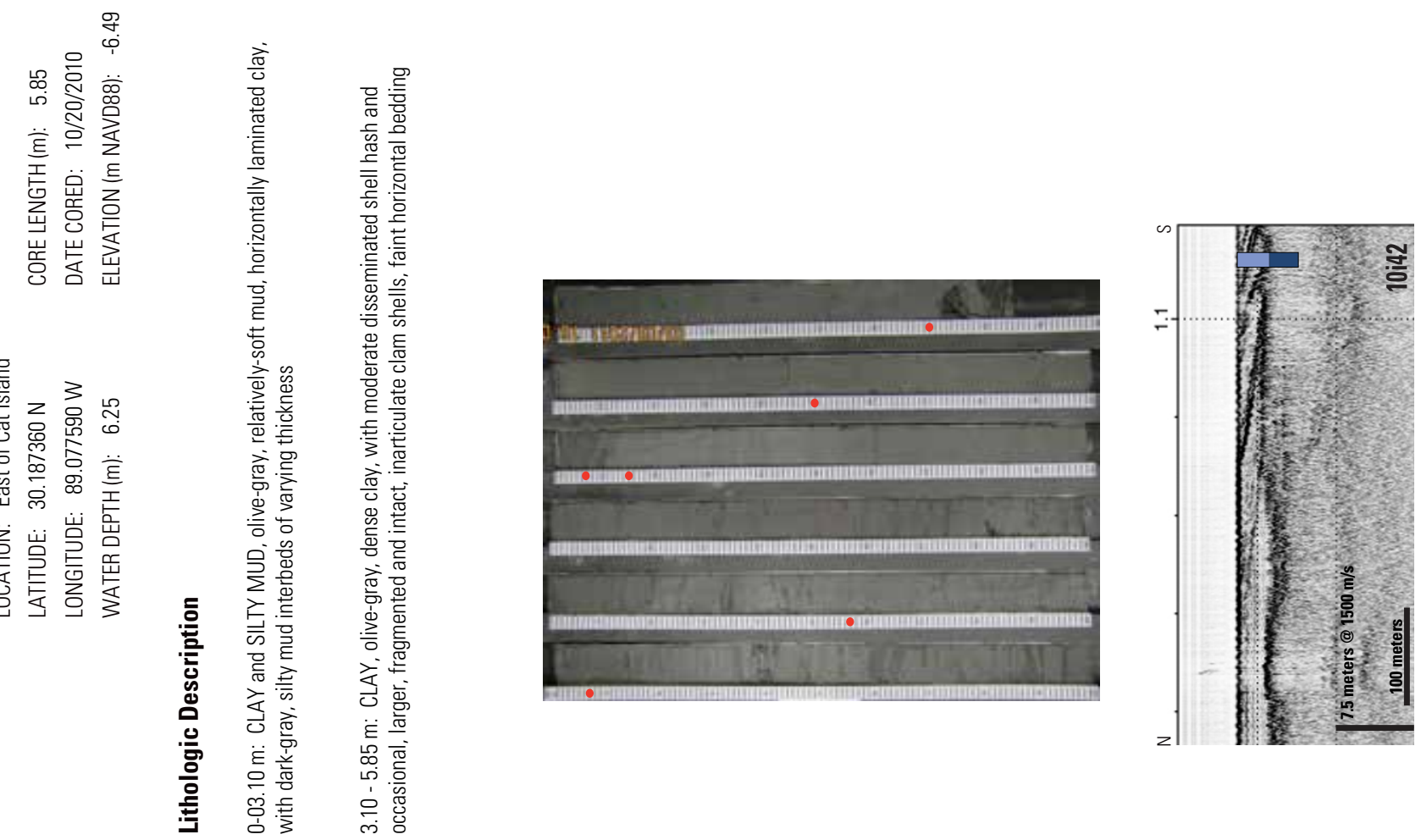

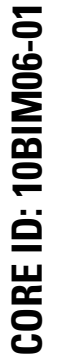
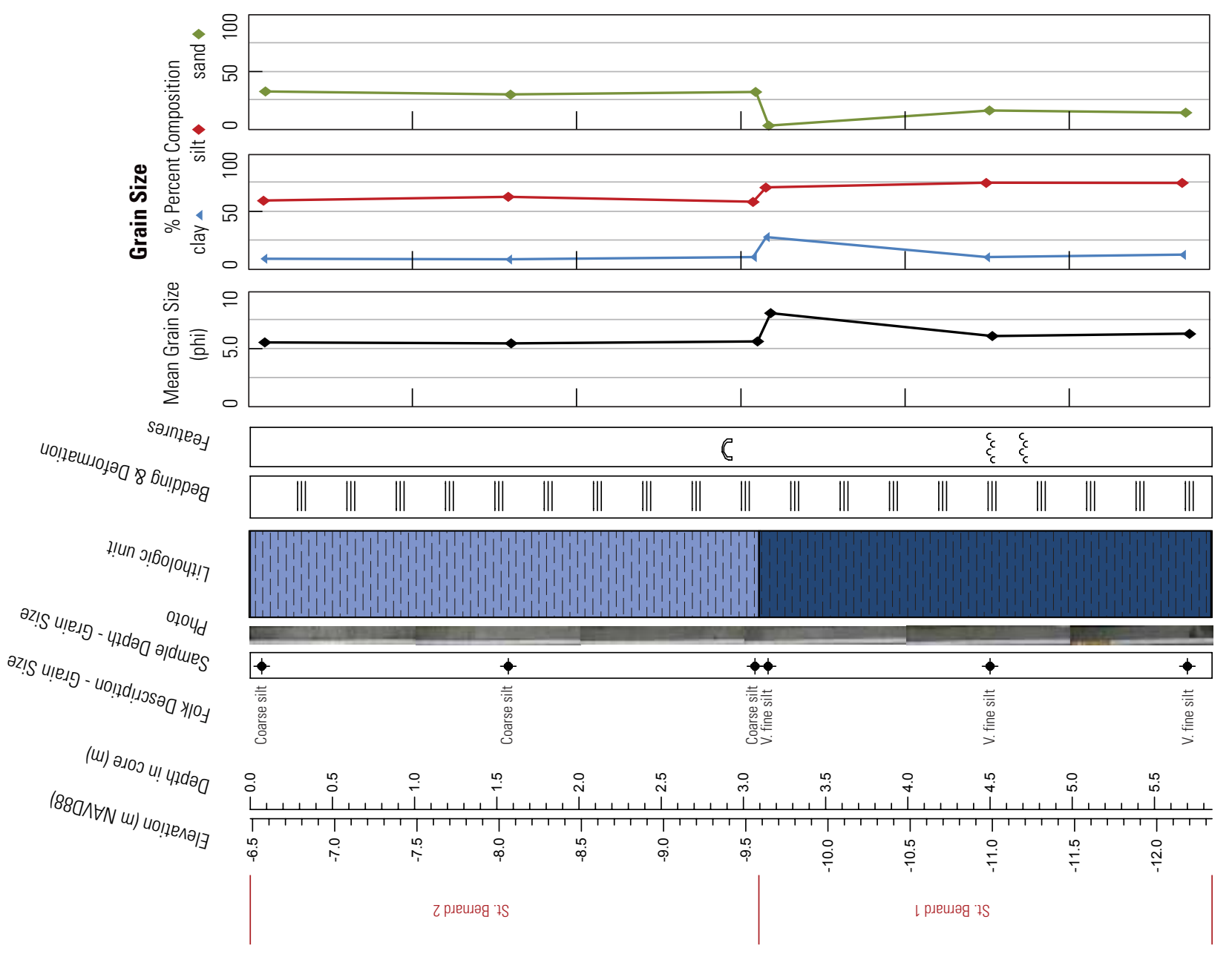


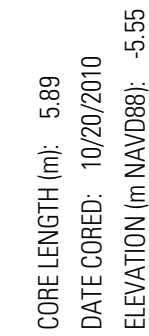
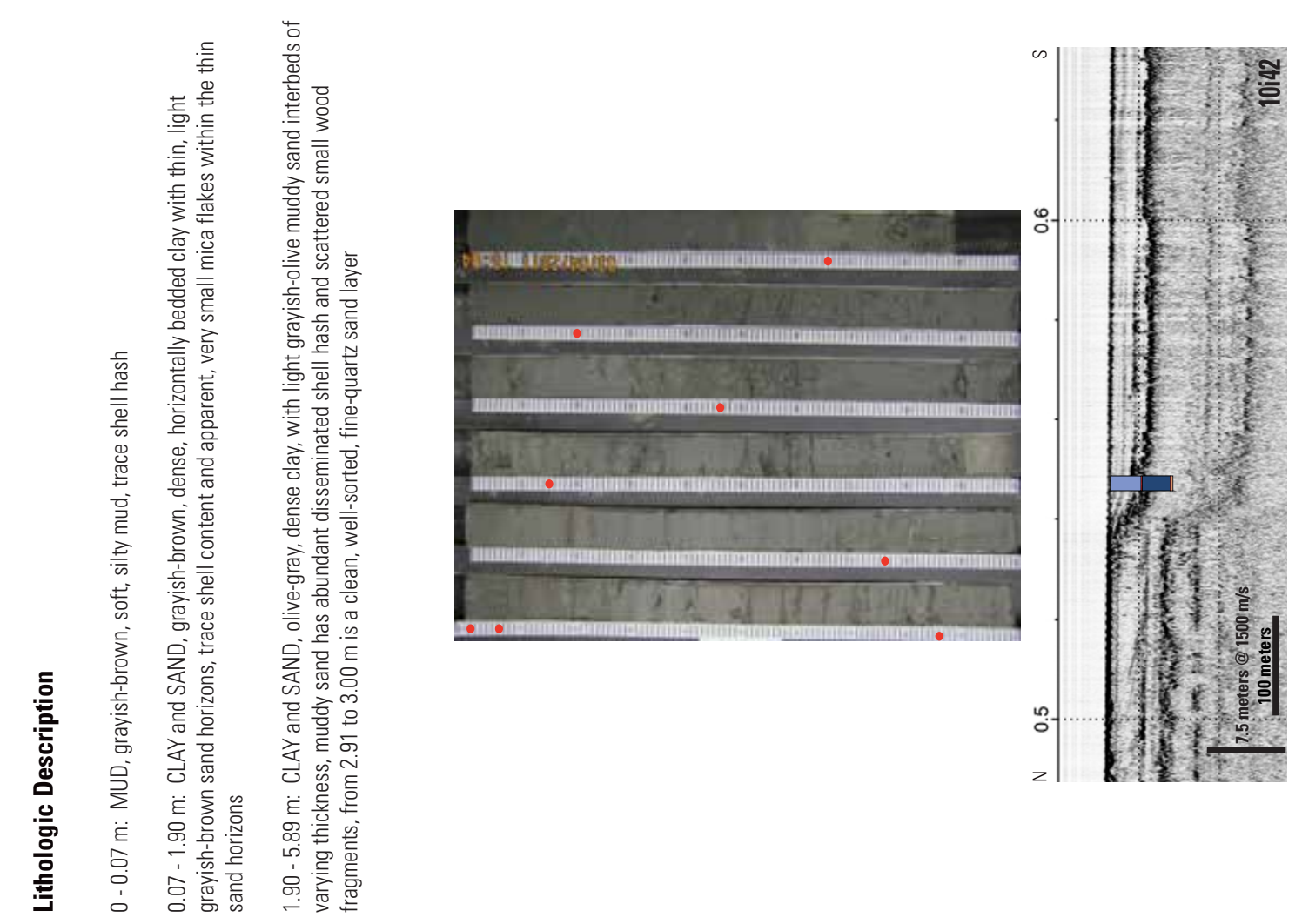

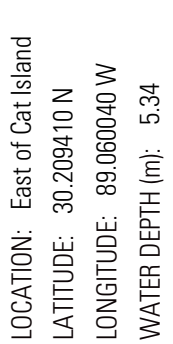
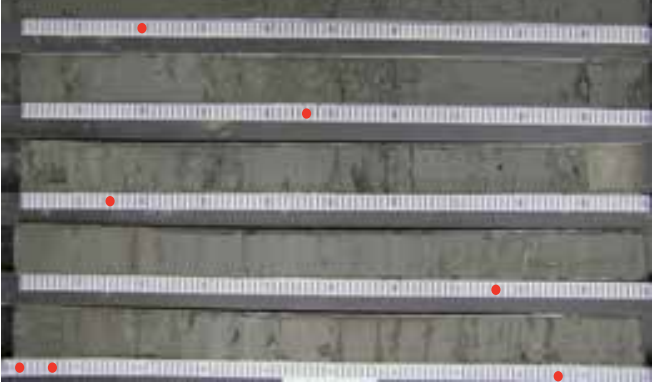

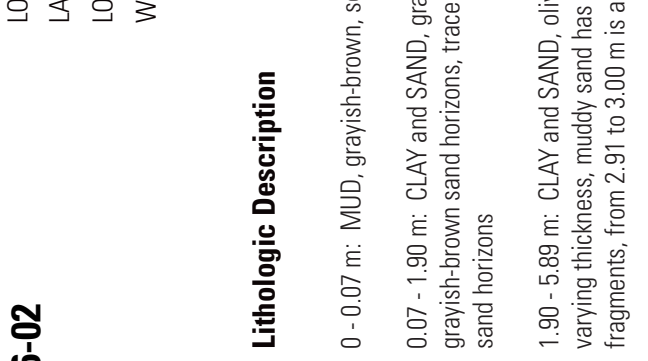

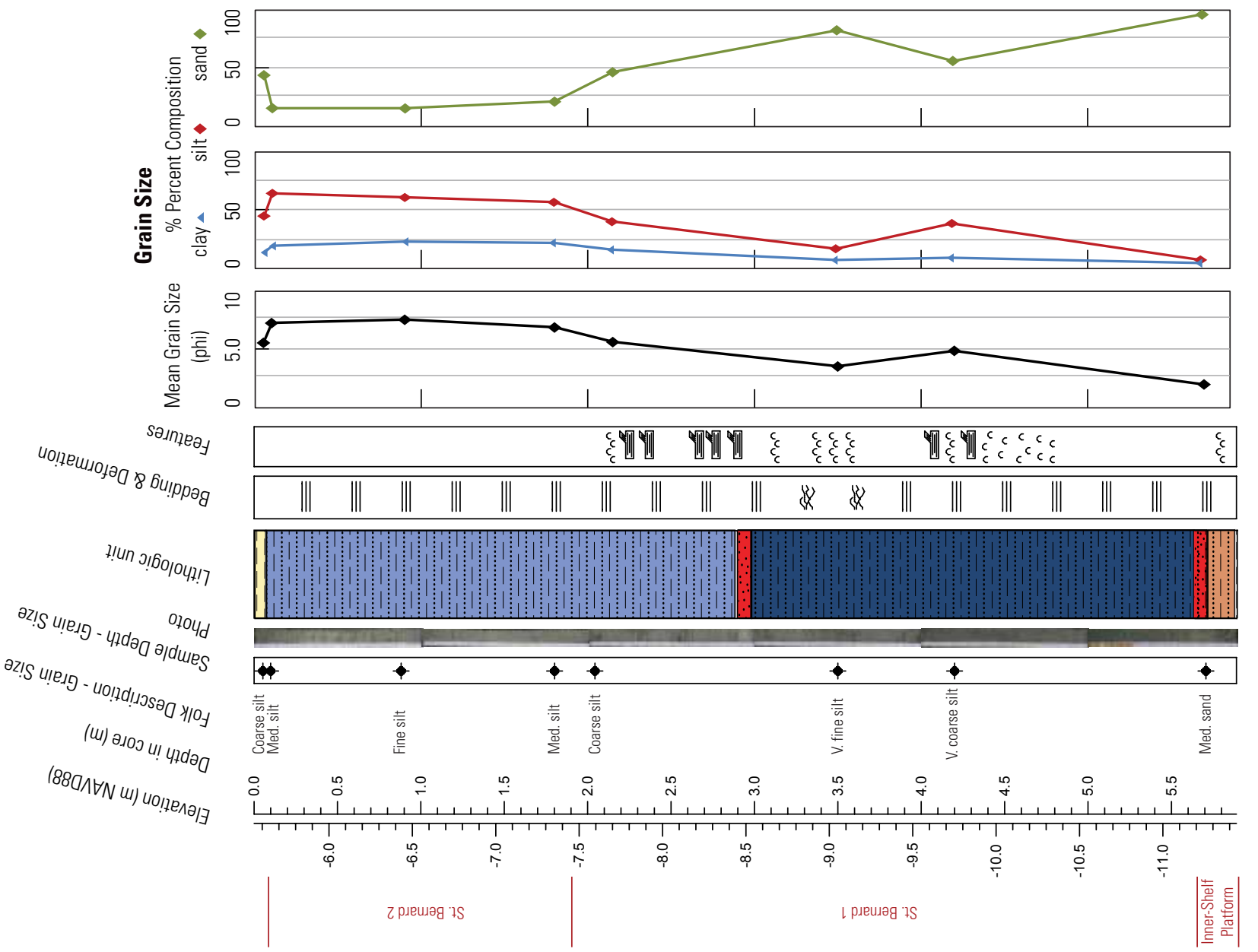

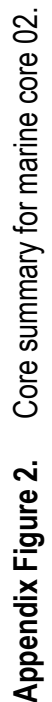



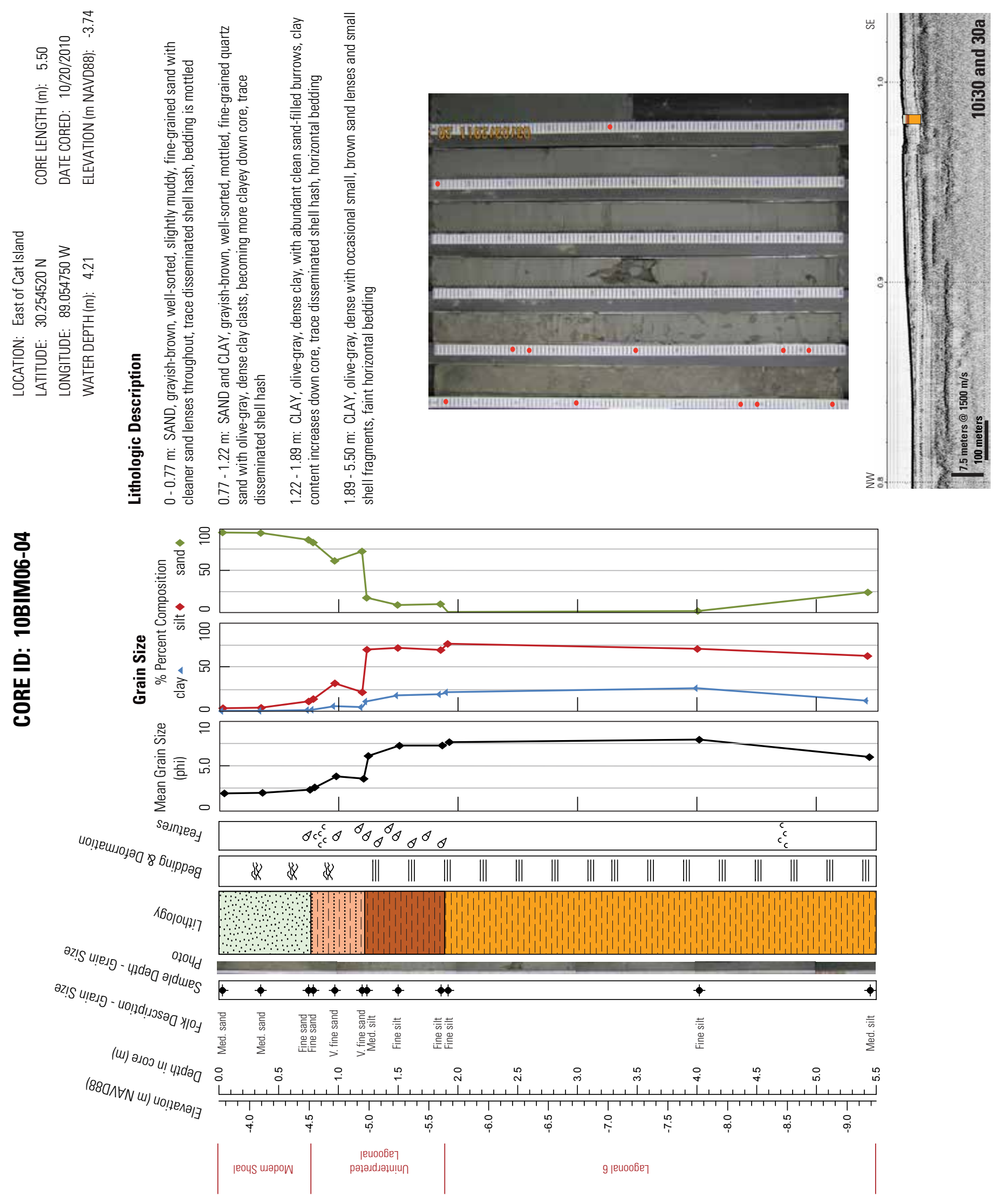

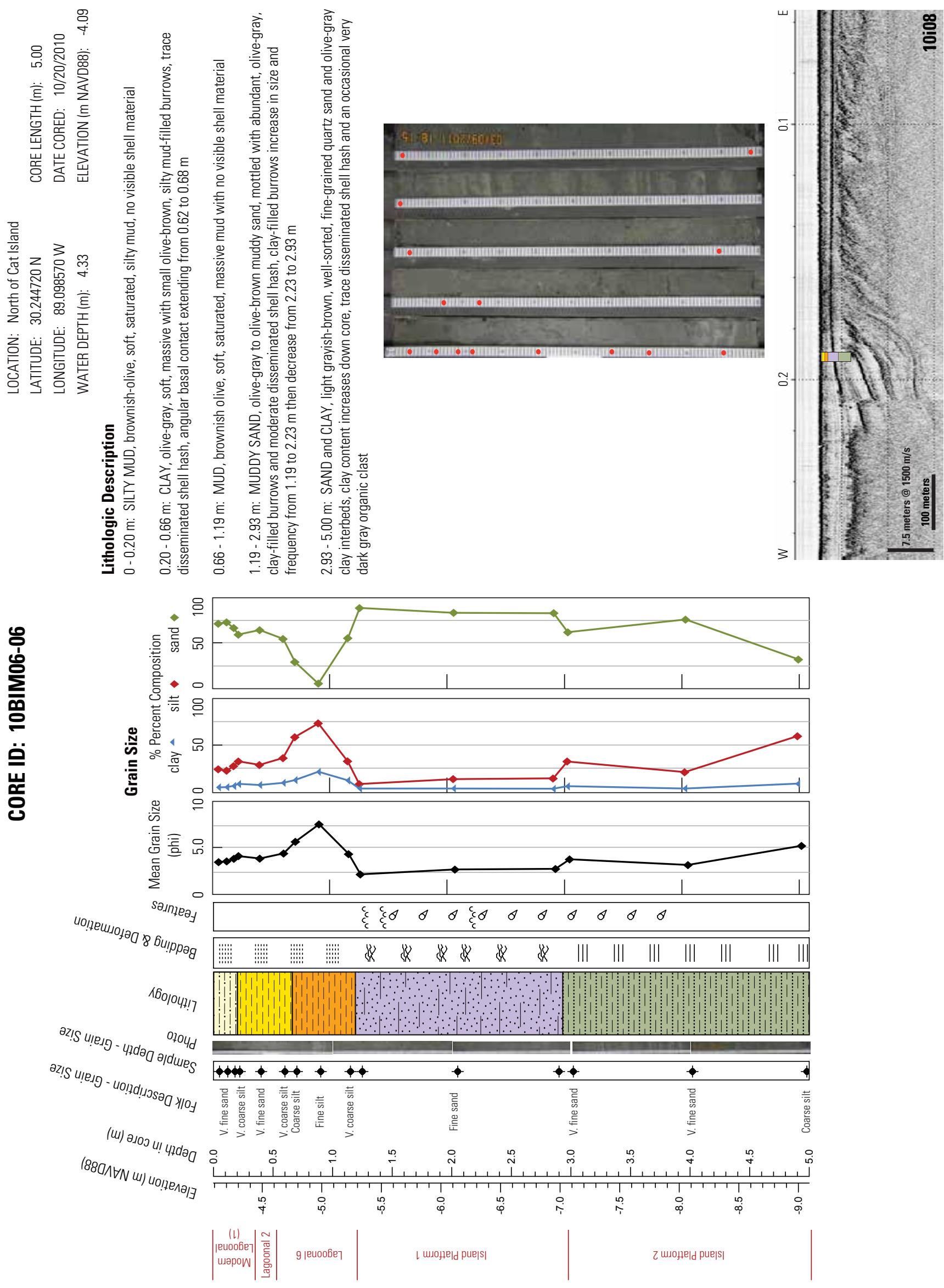

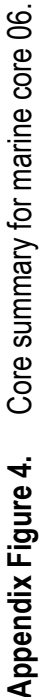



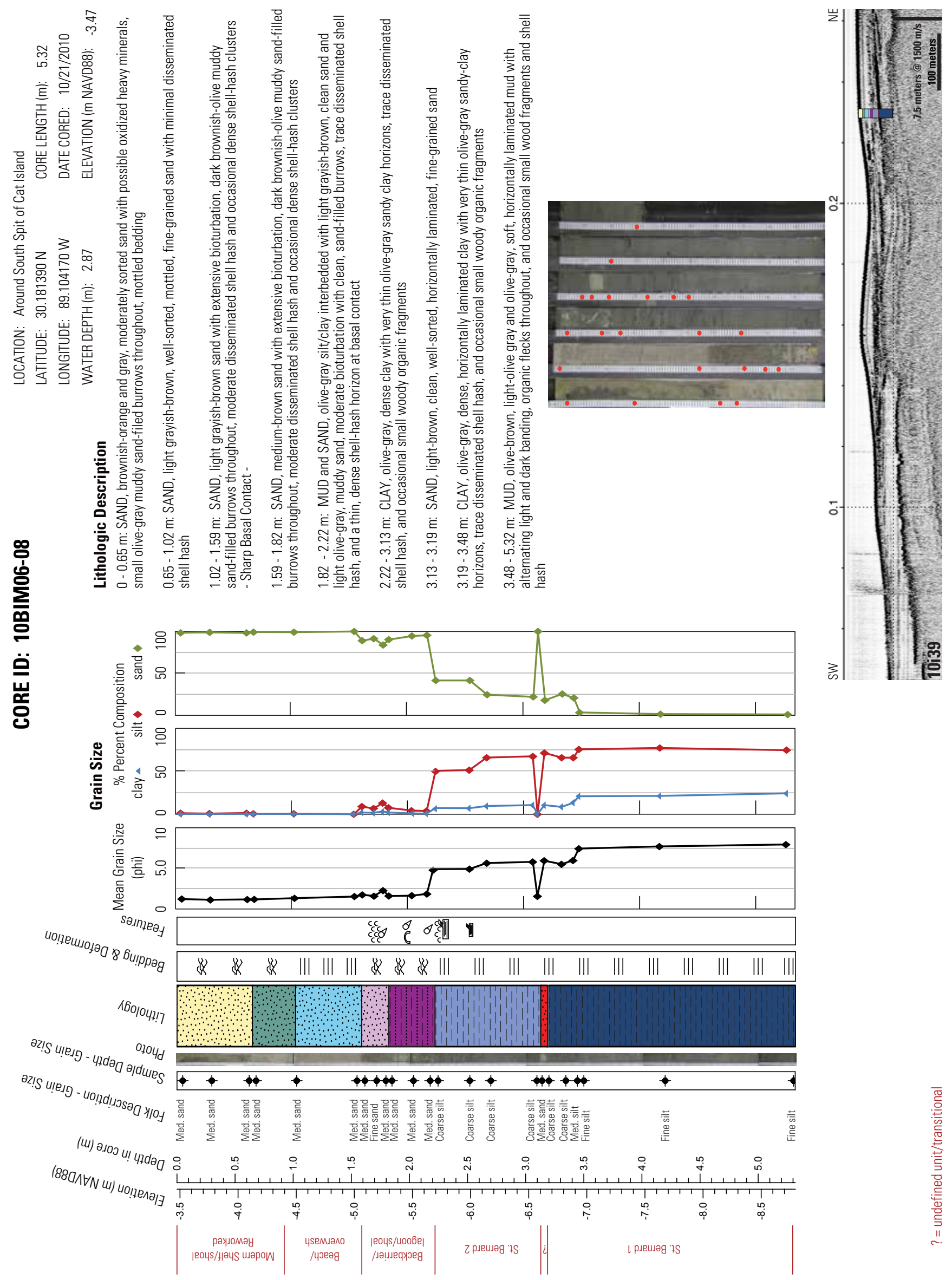


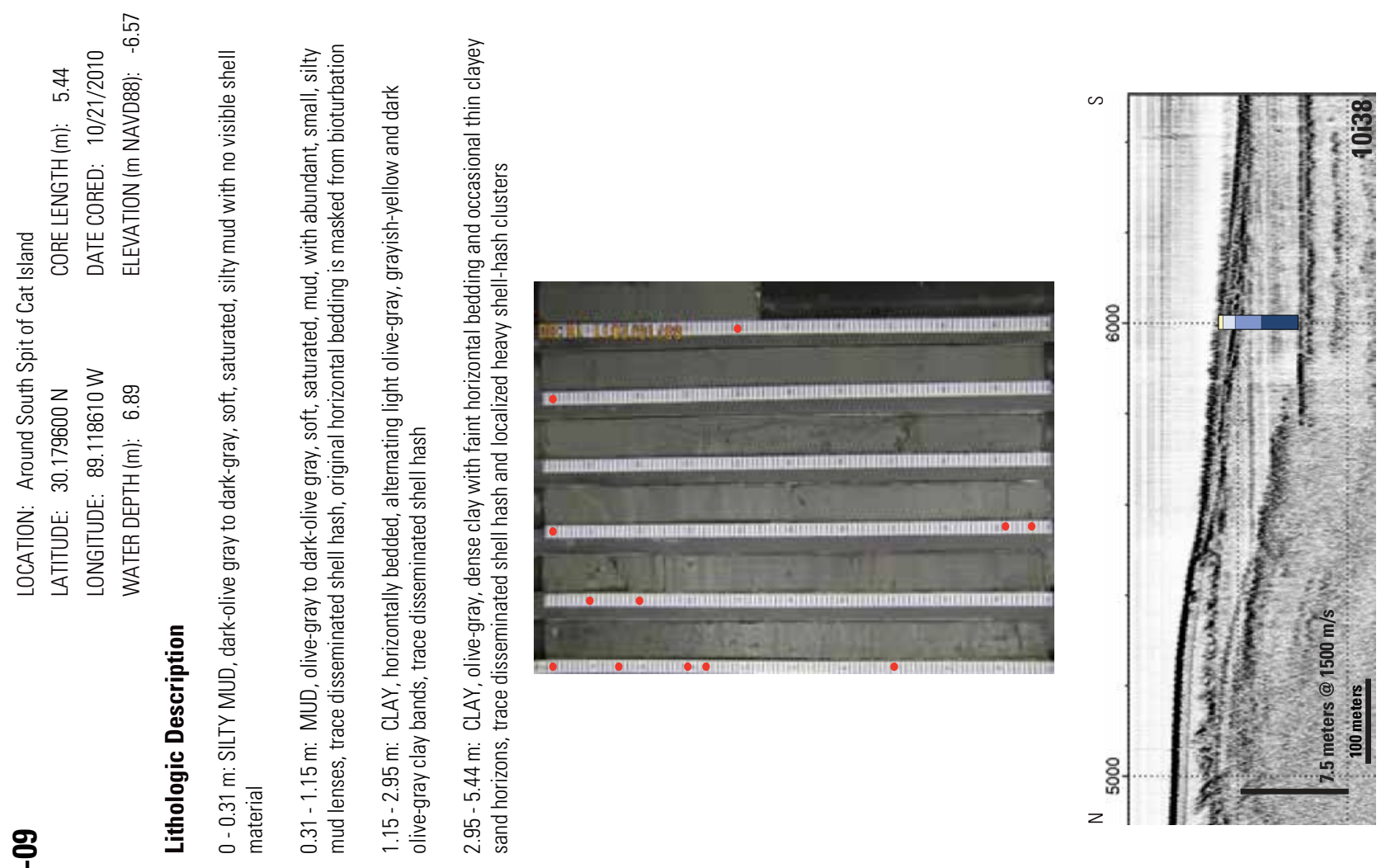

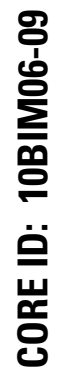
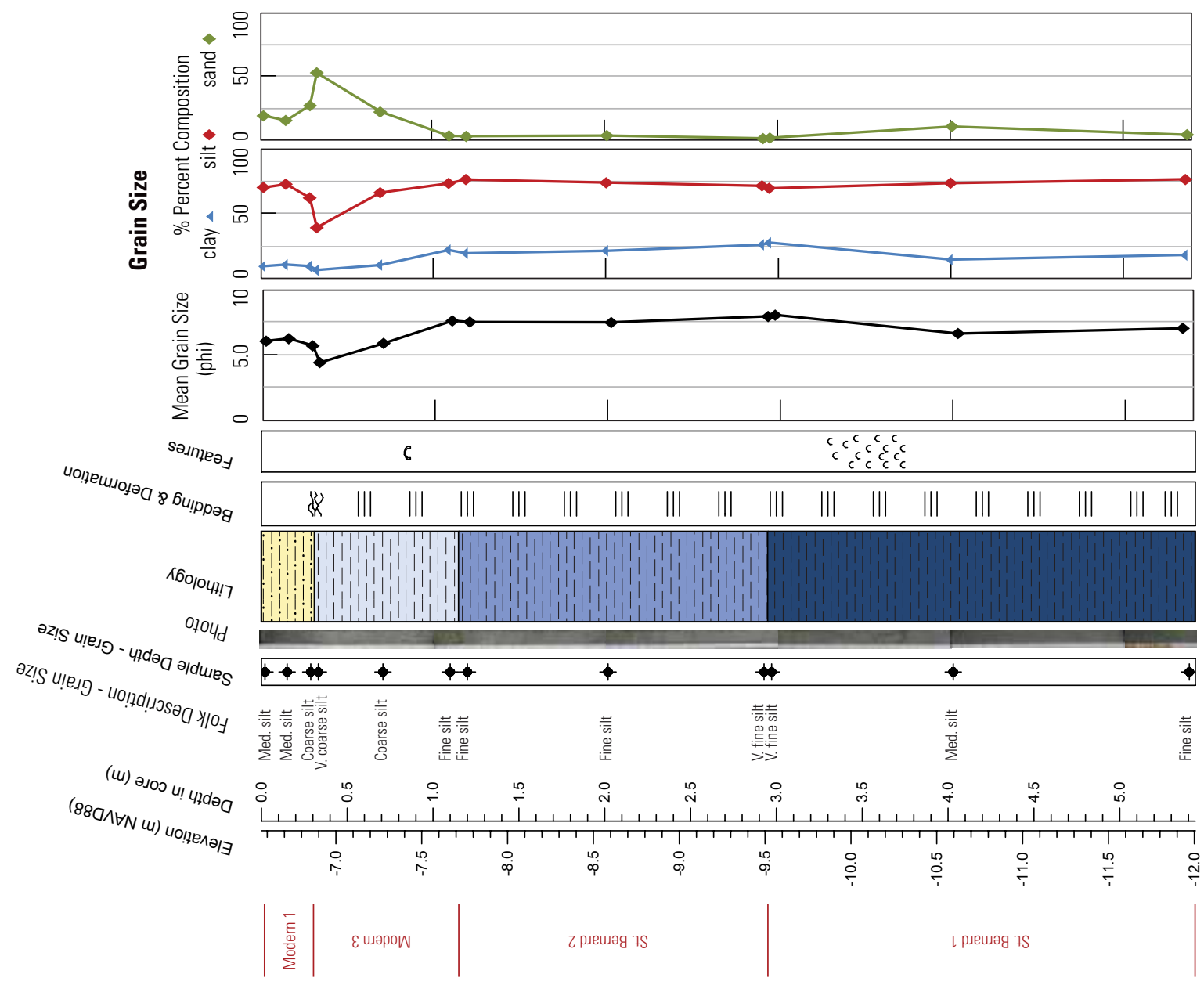

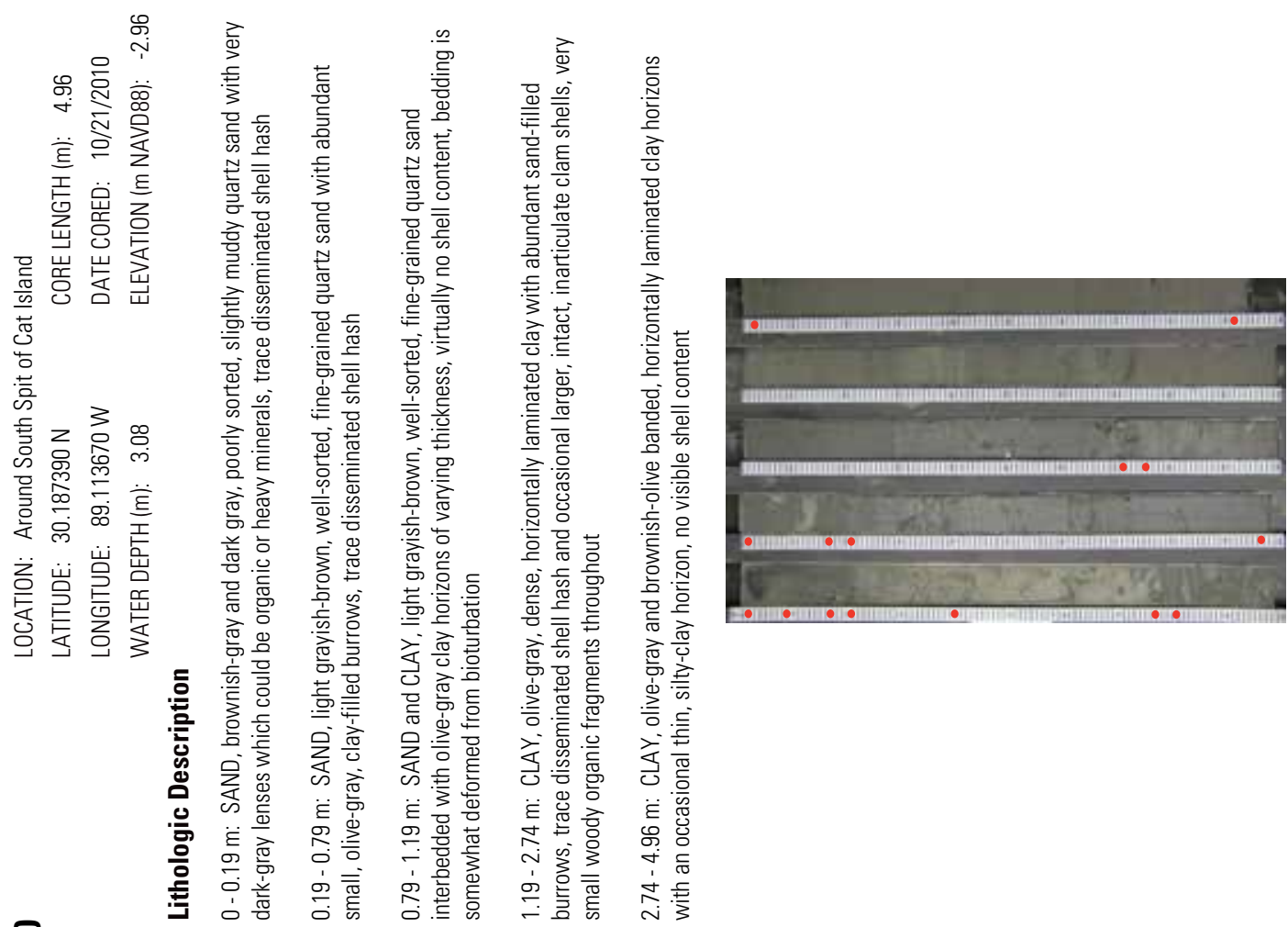

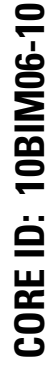
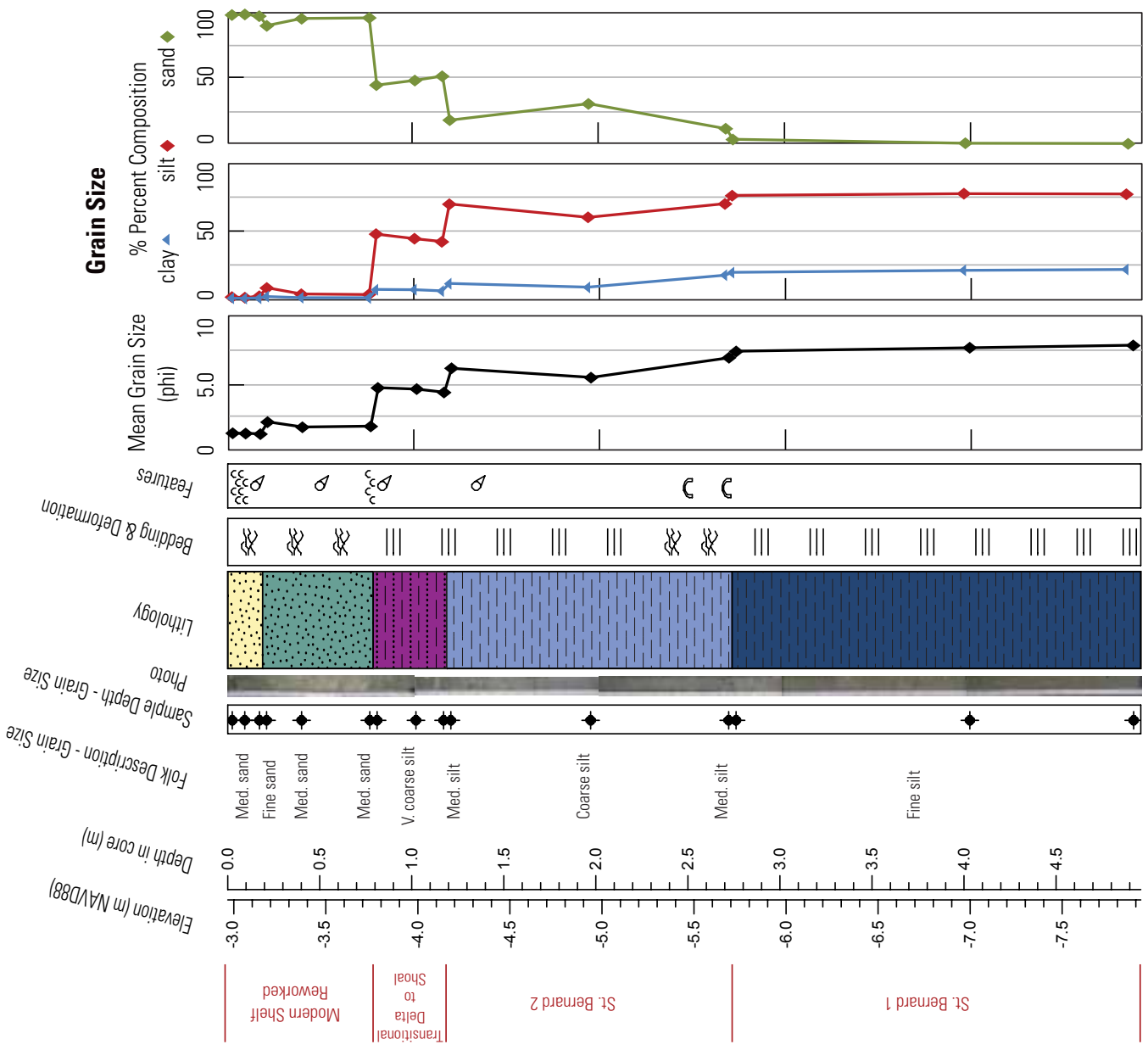


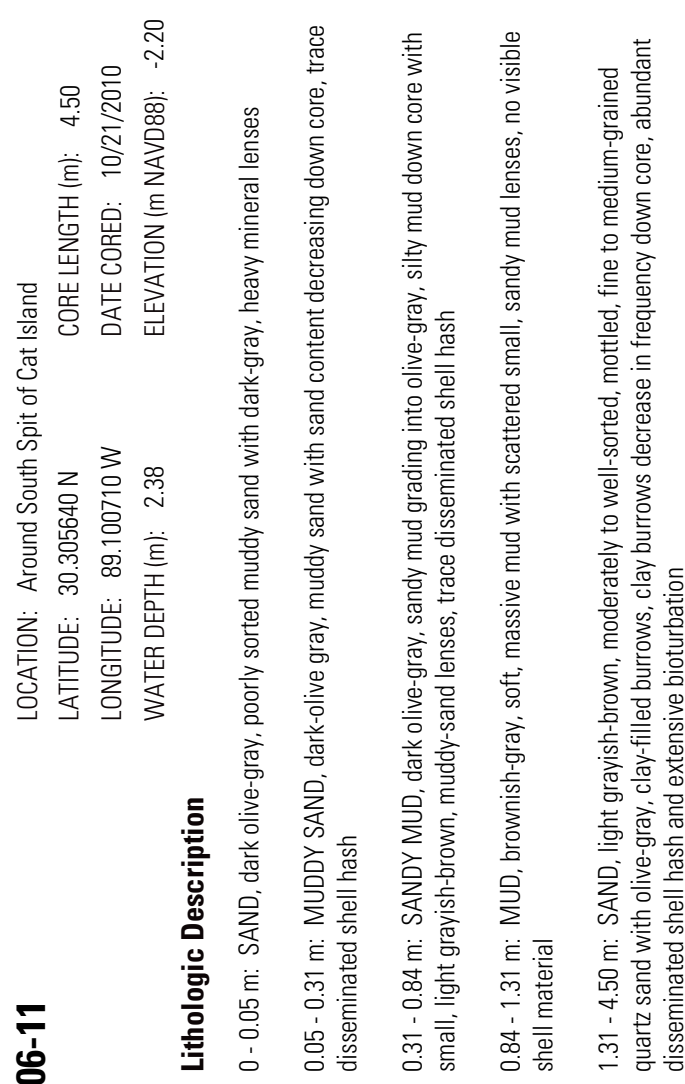
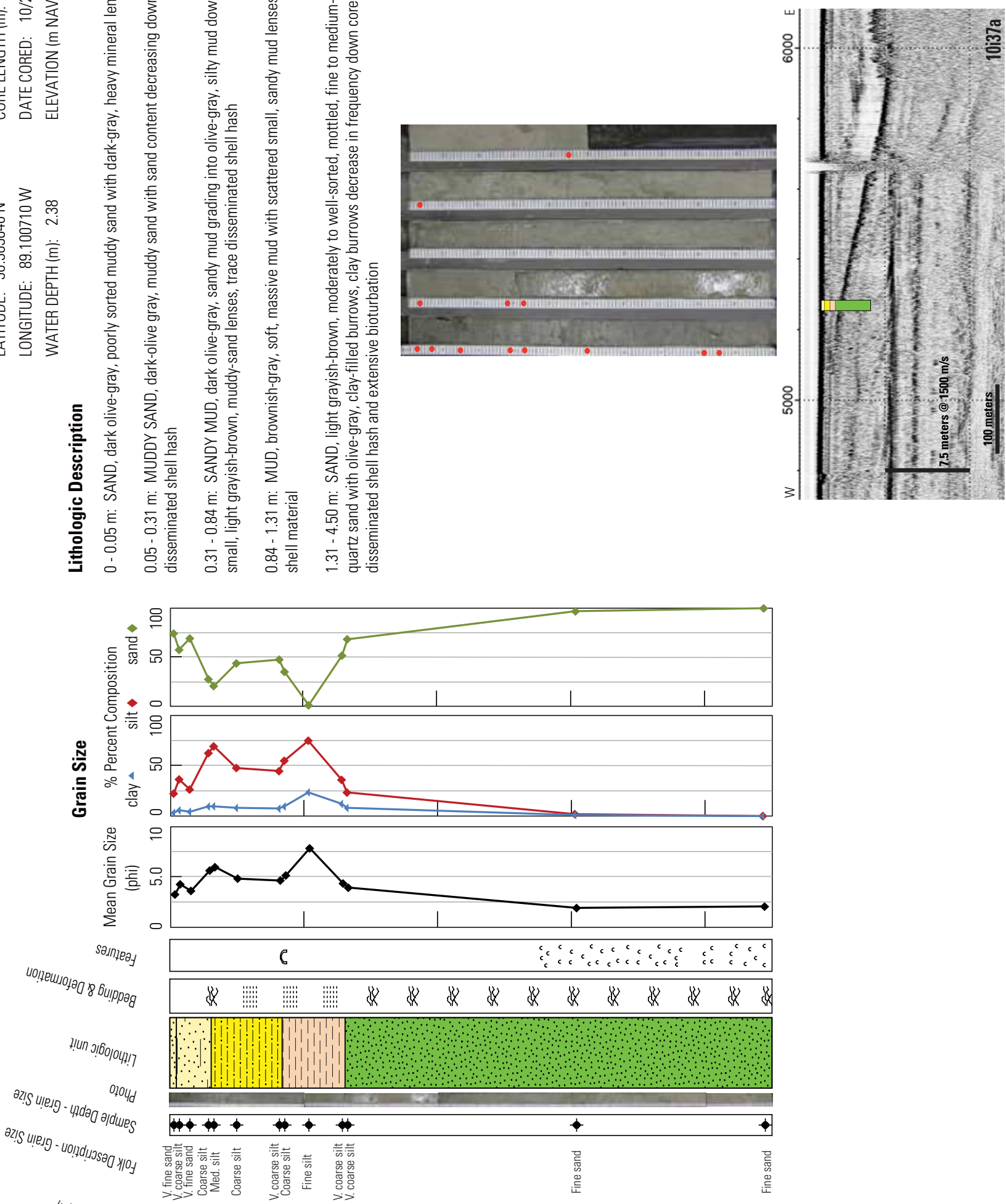

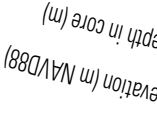

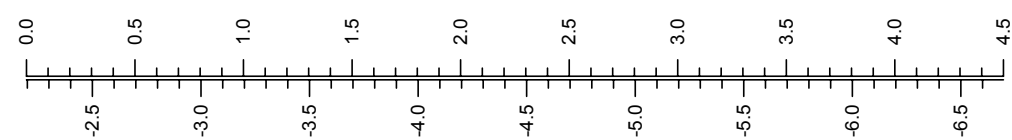

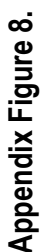




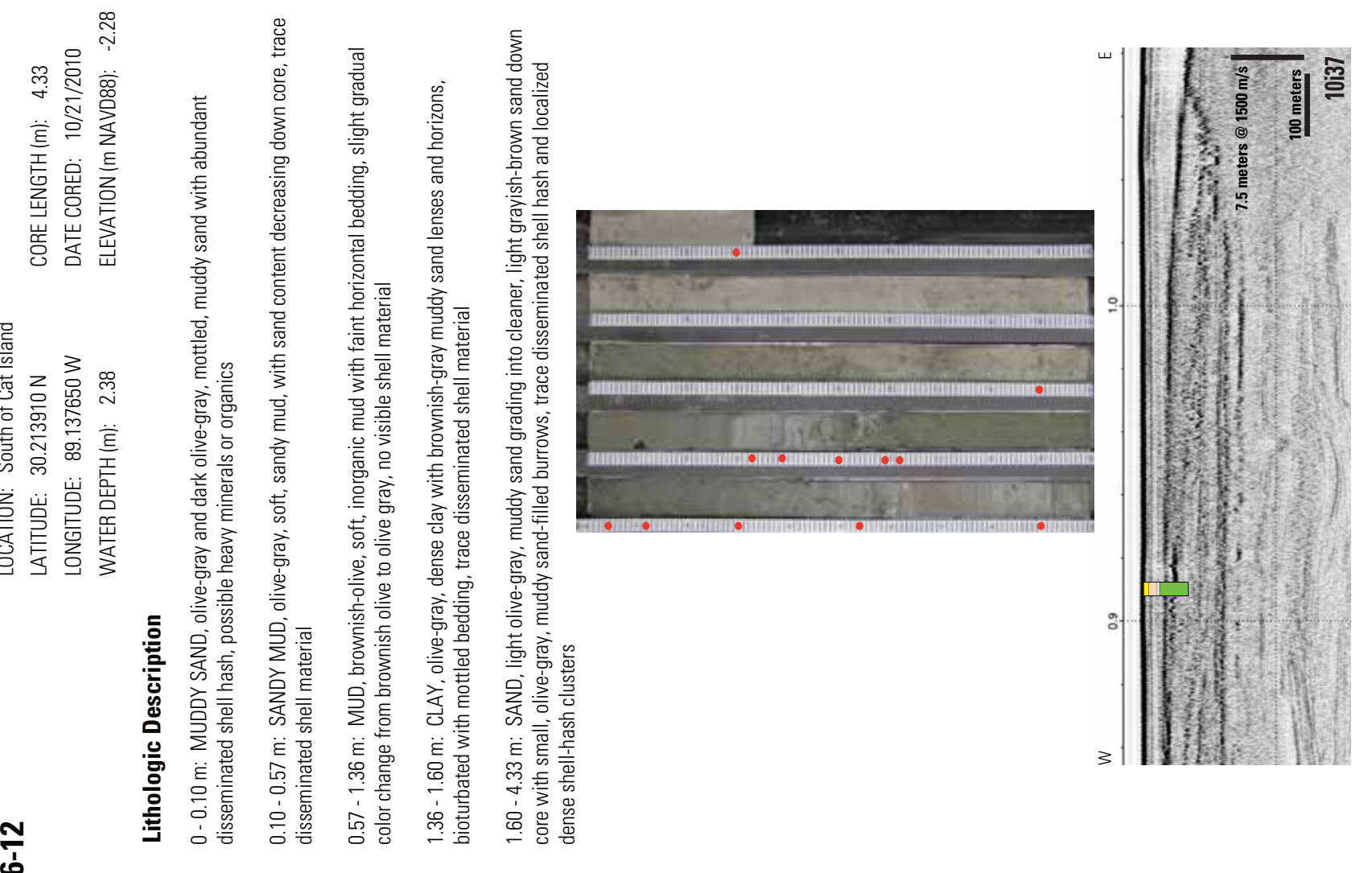


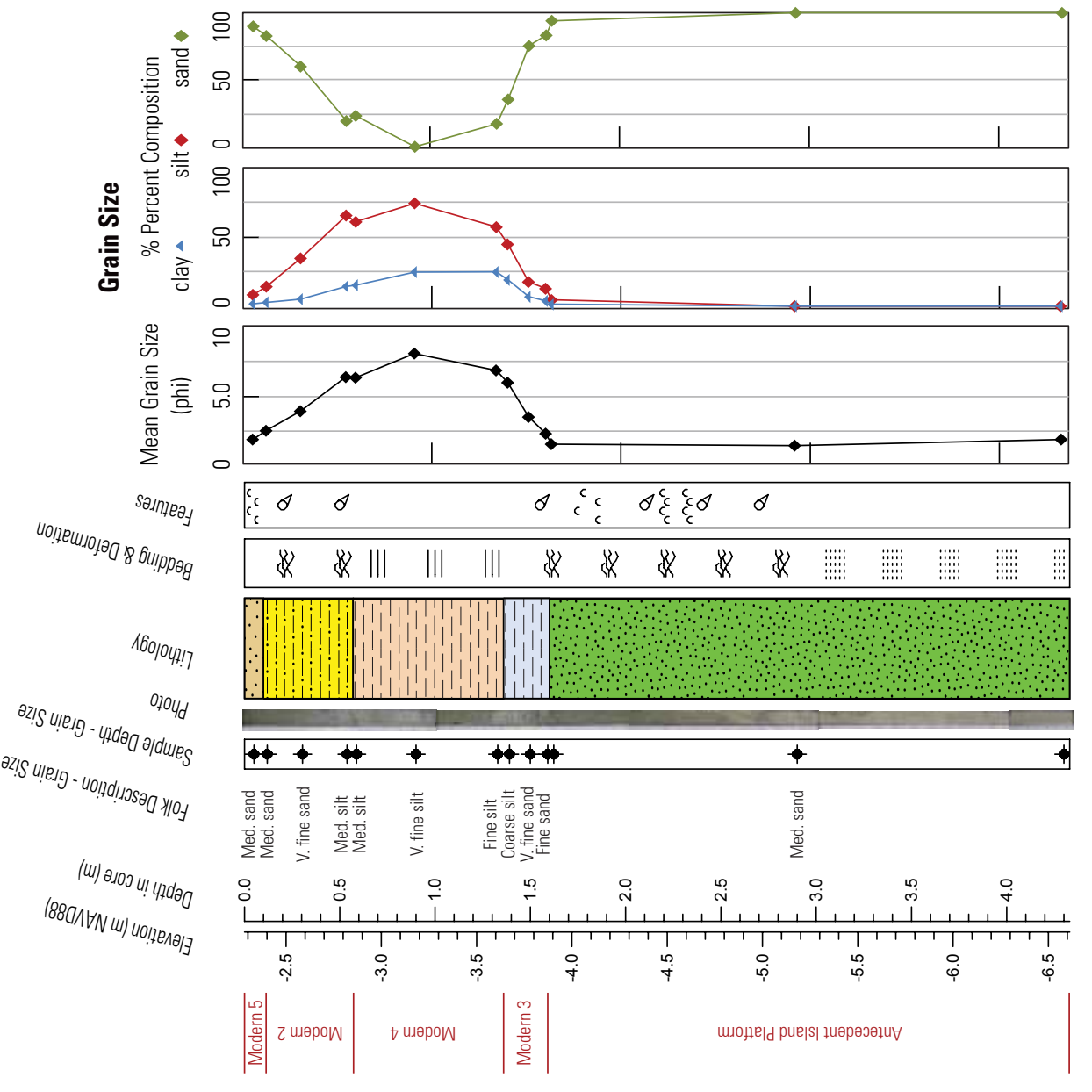

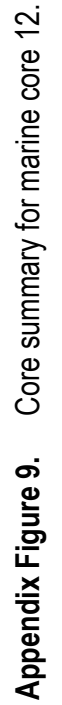




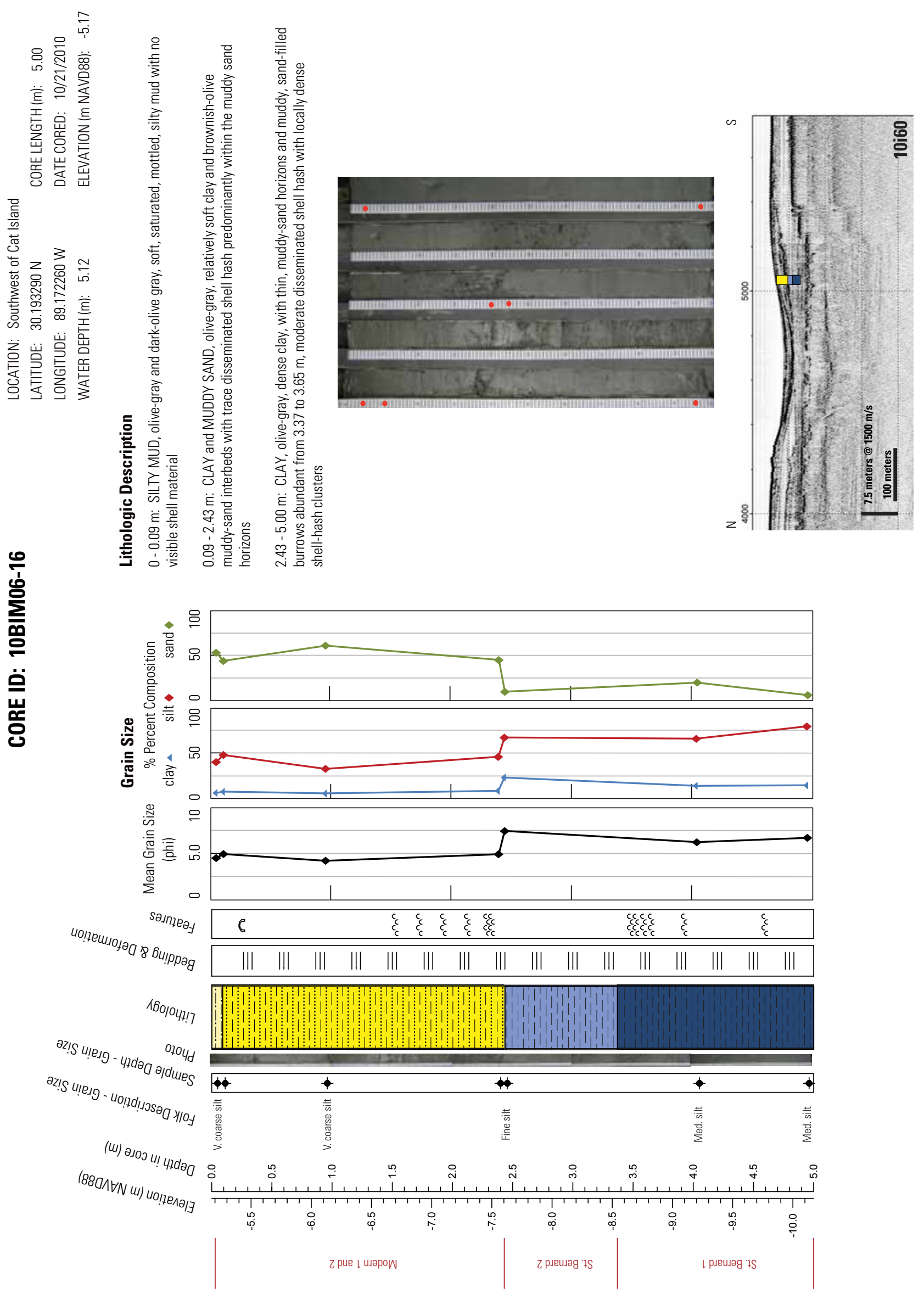

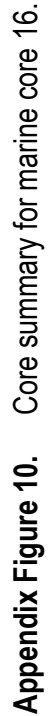




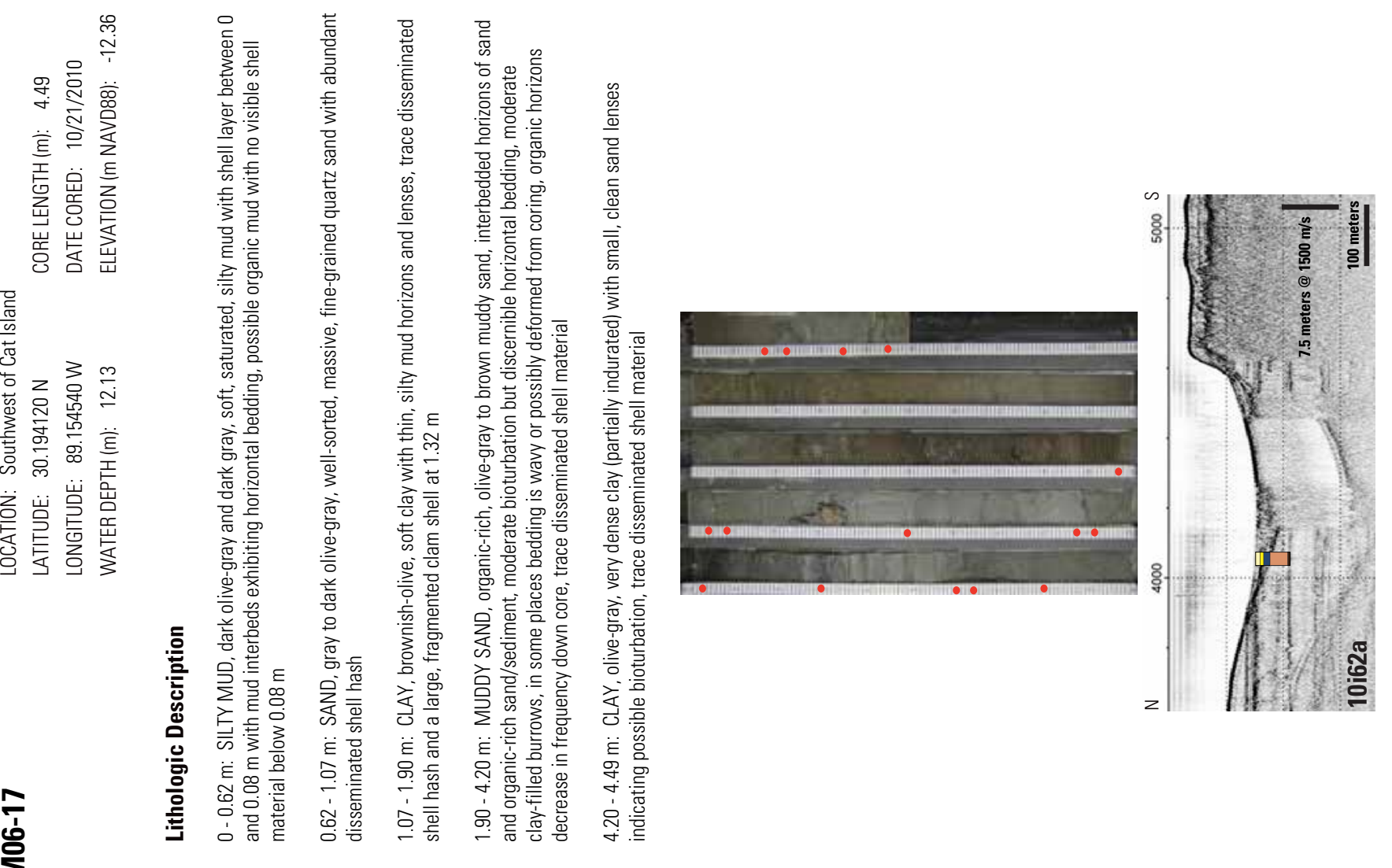

음
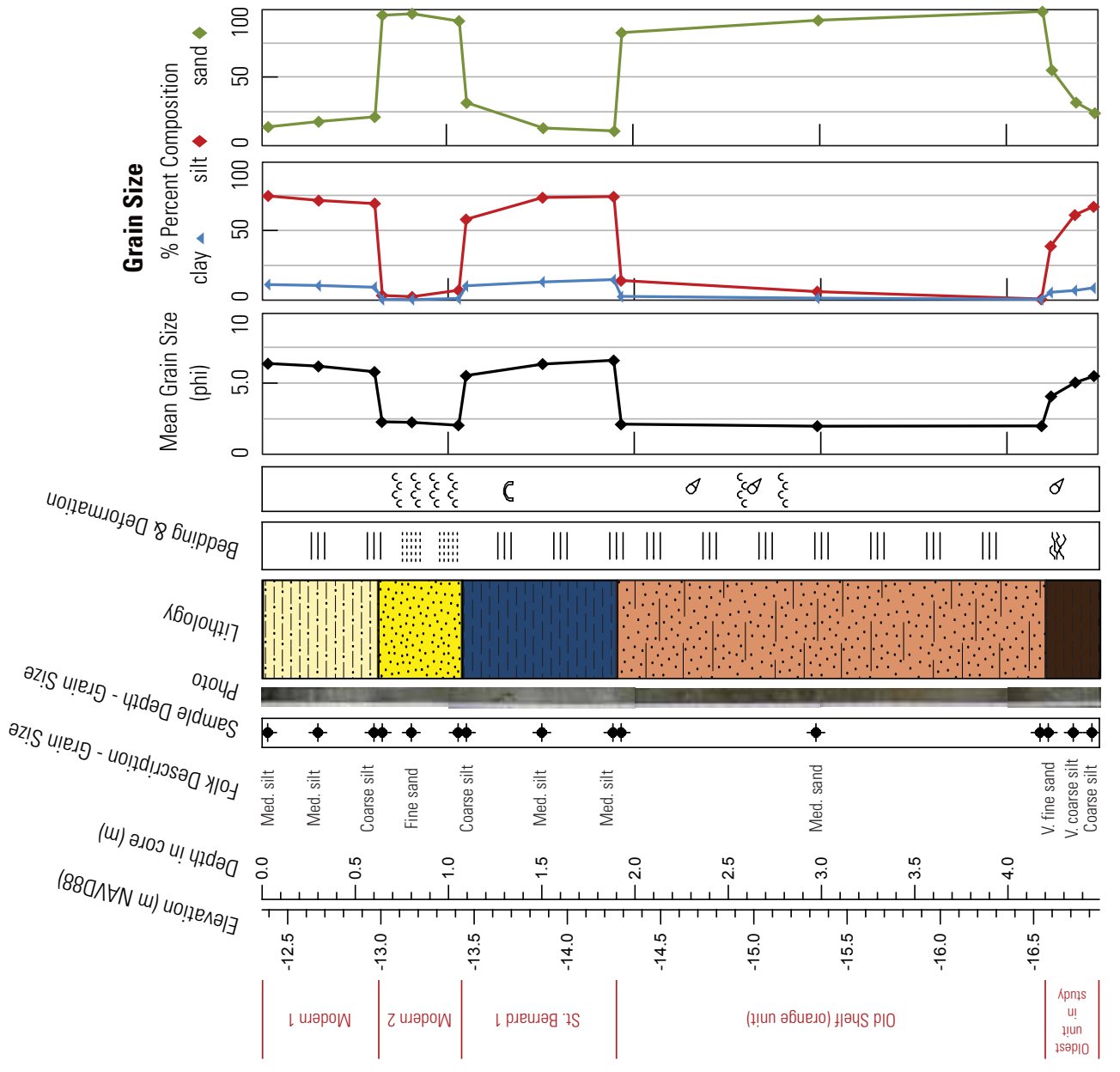

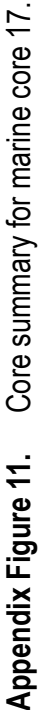




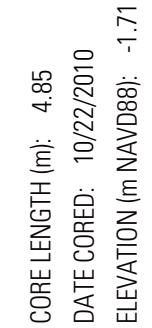
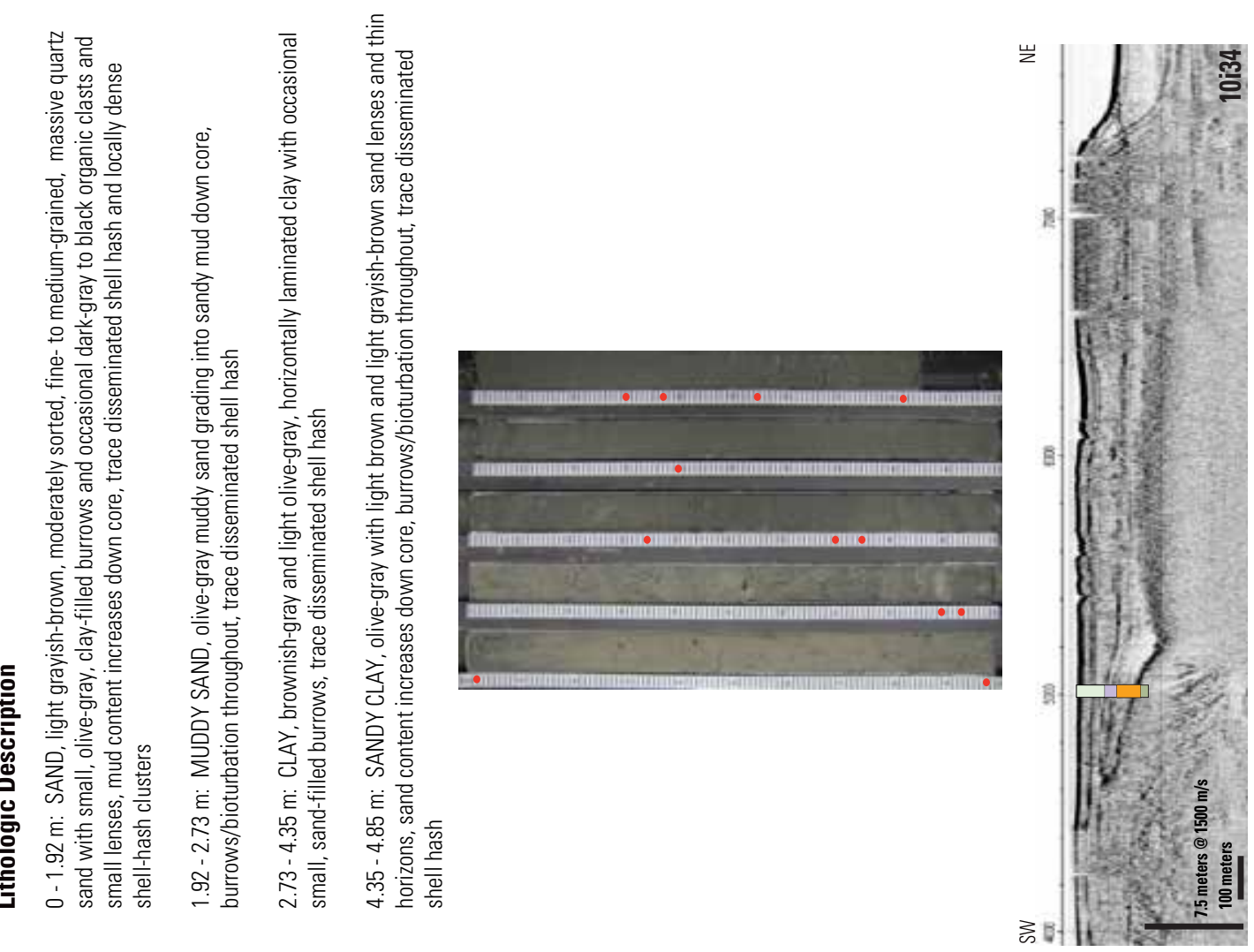

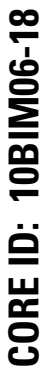

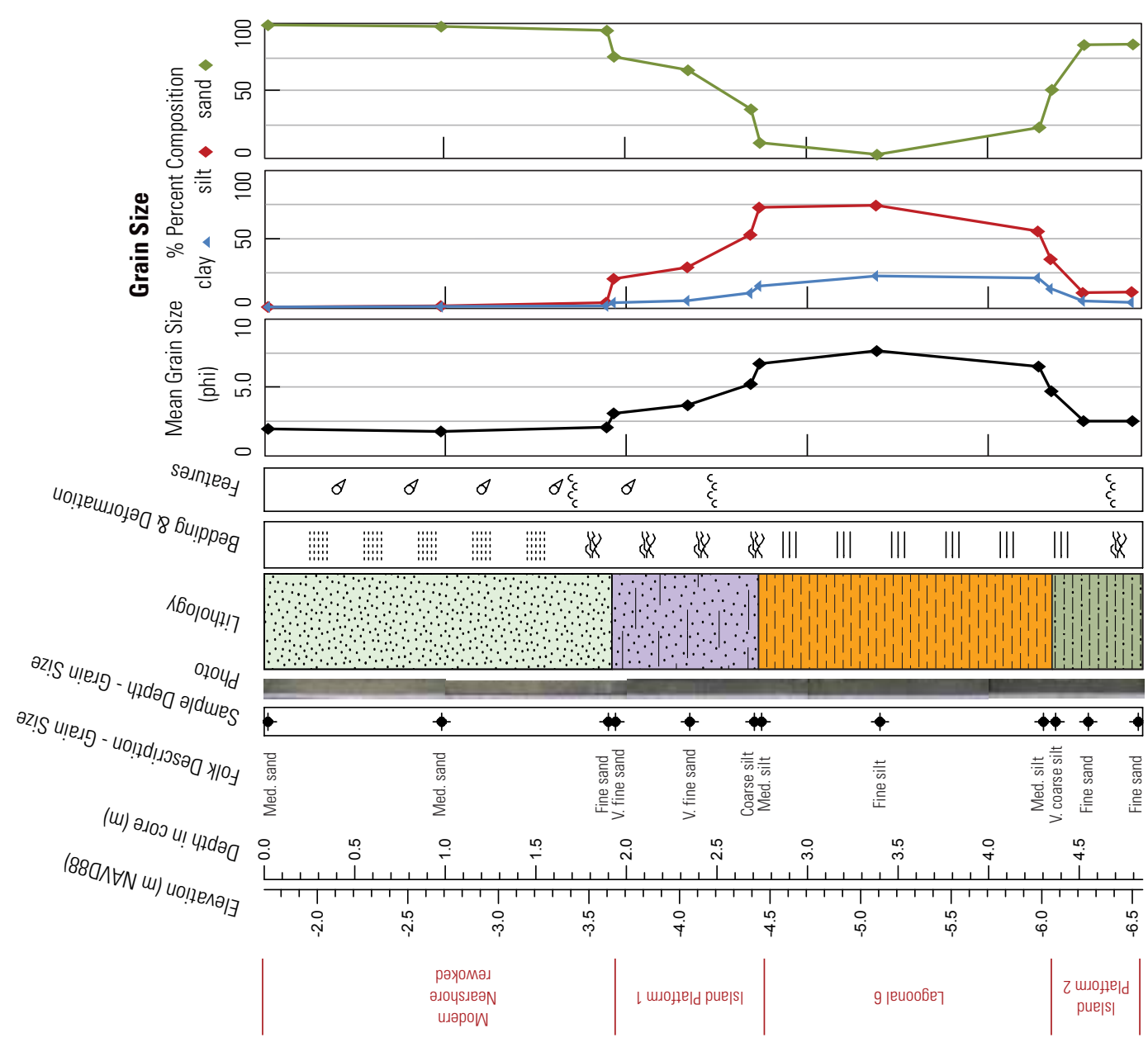




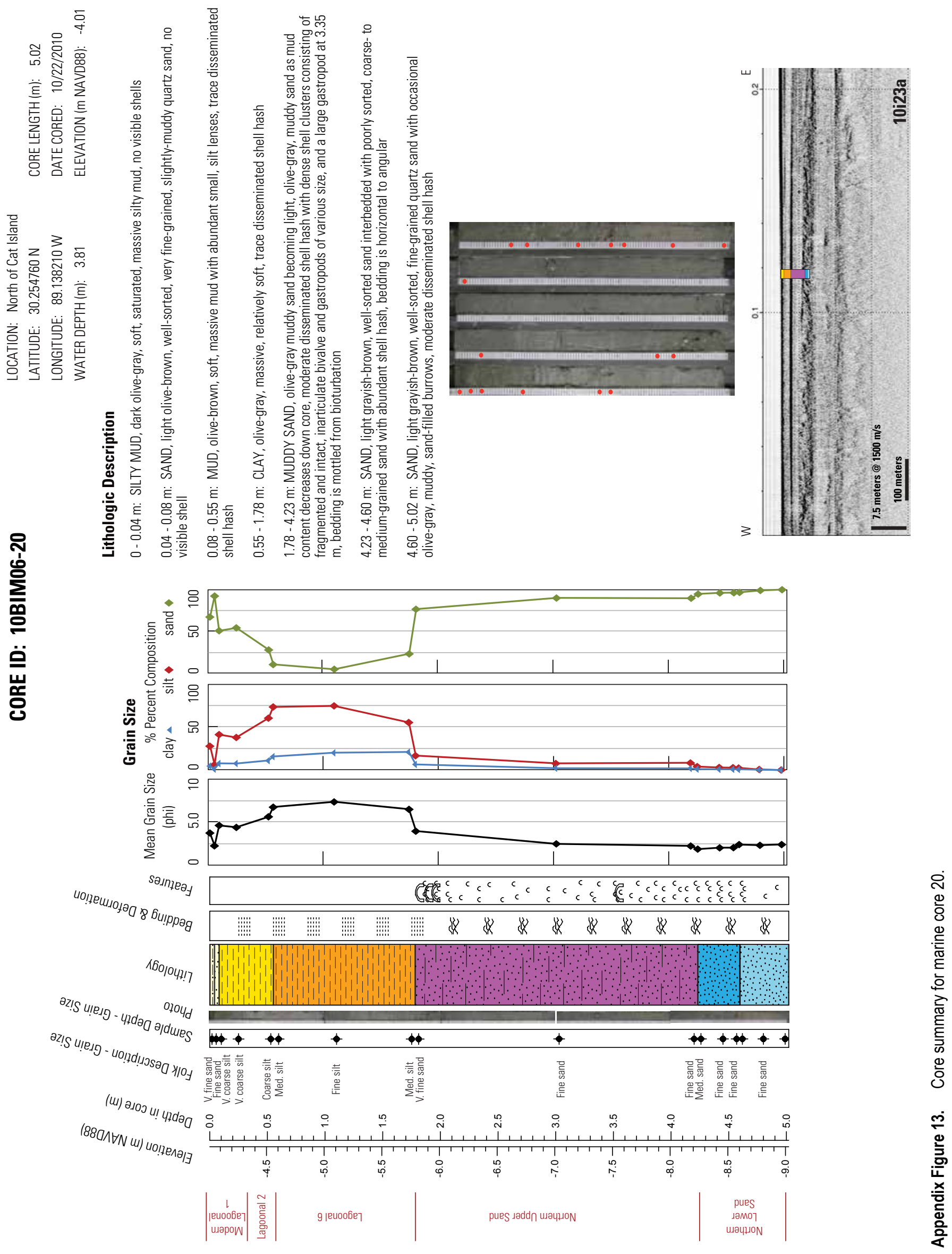




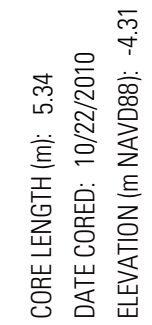
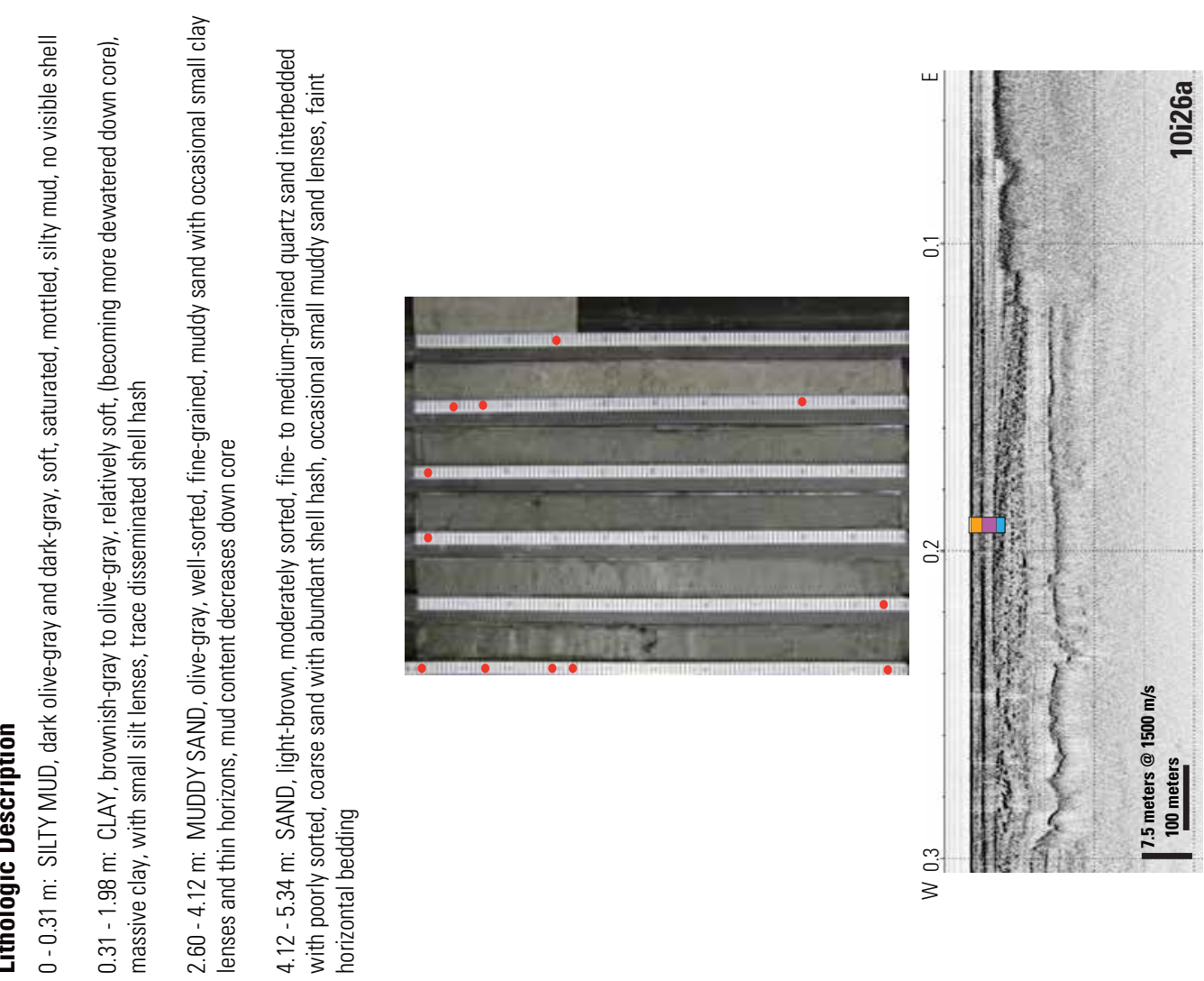

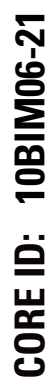
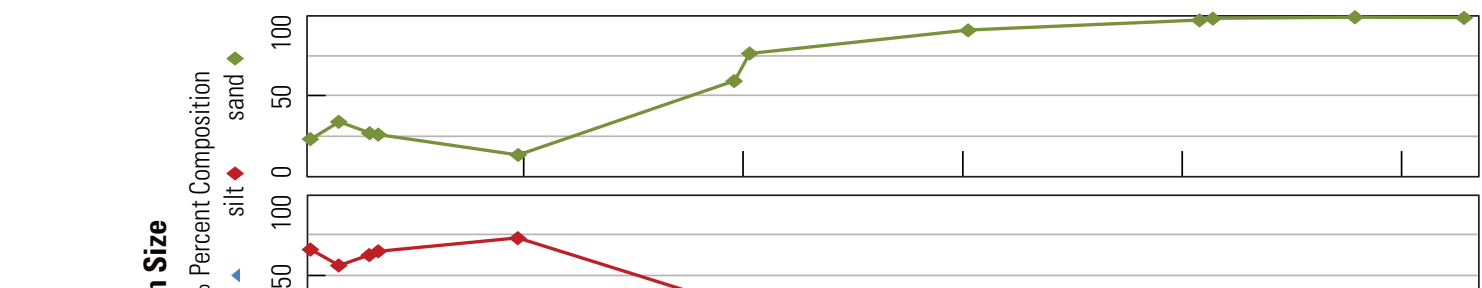

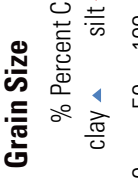

离

电
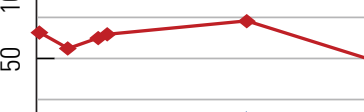

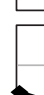

高

$\sum_{2}^{\infty}$

$\circ$
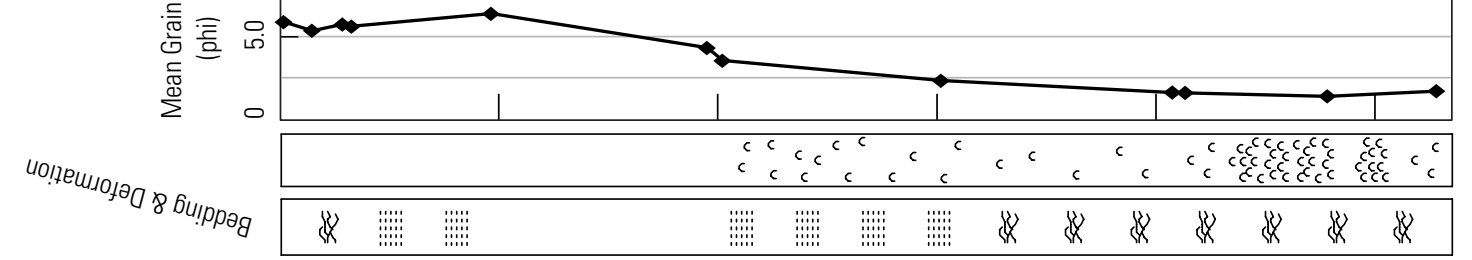

$160104+17$

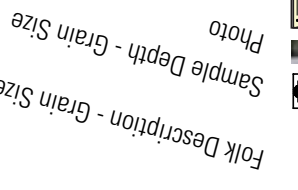
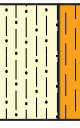

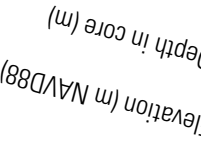
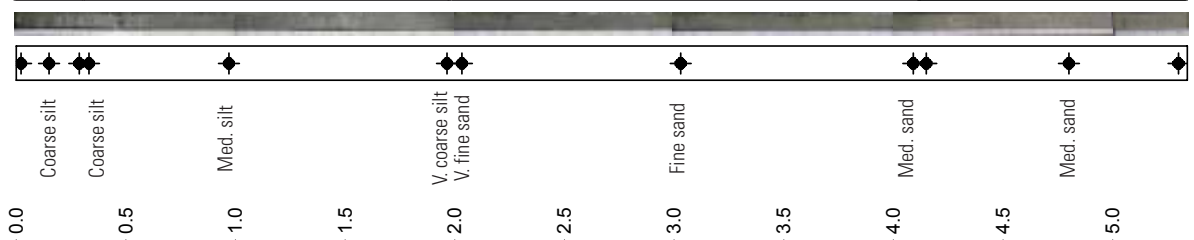

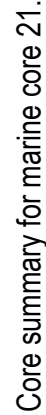

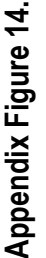




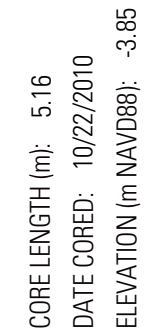
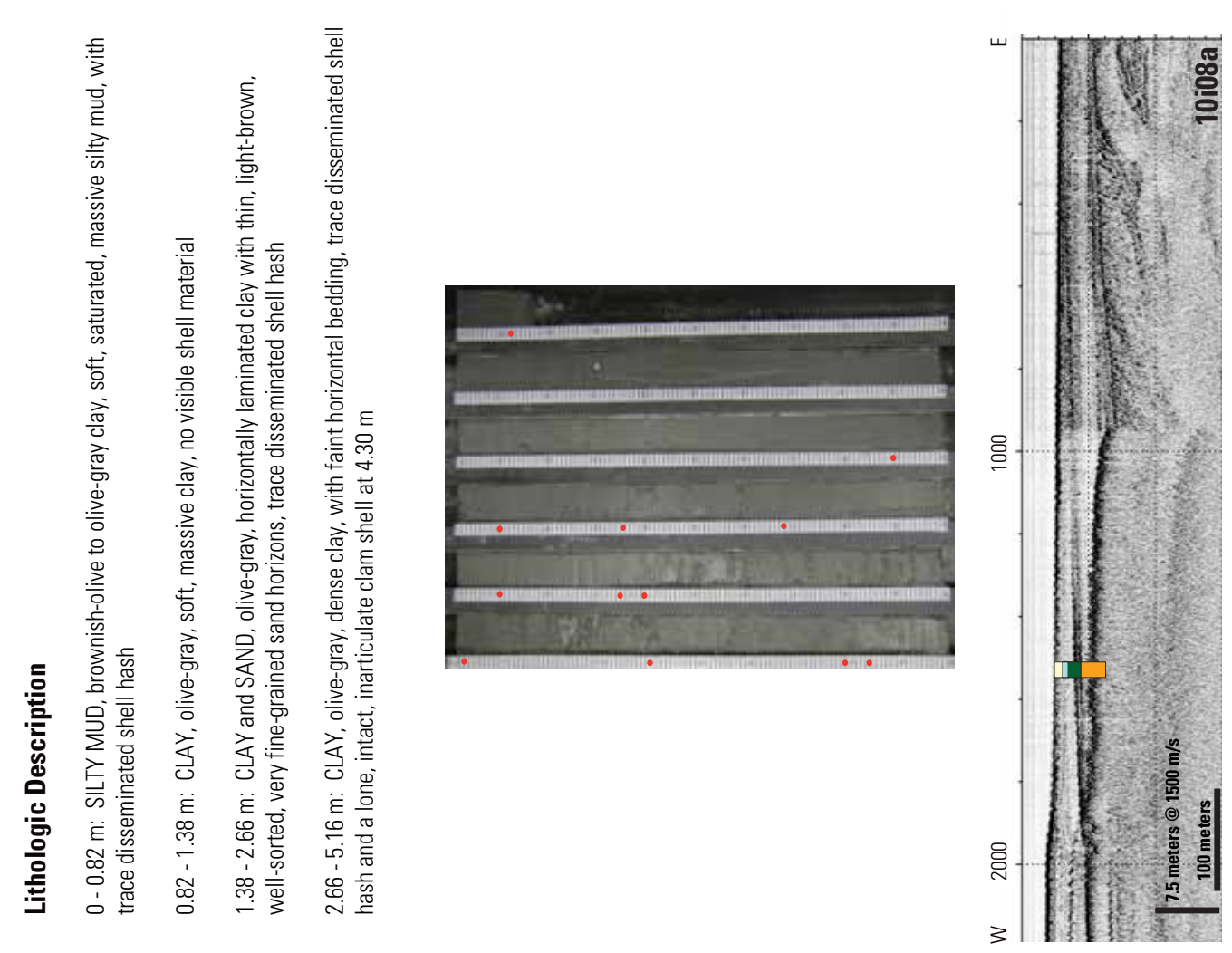

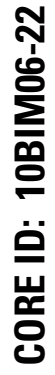

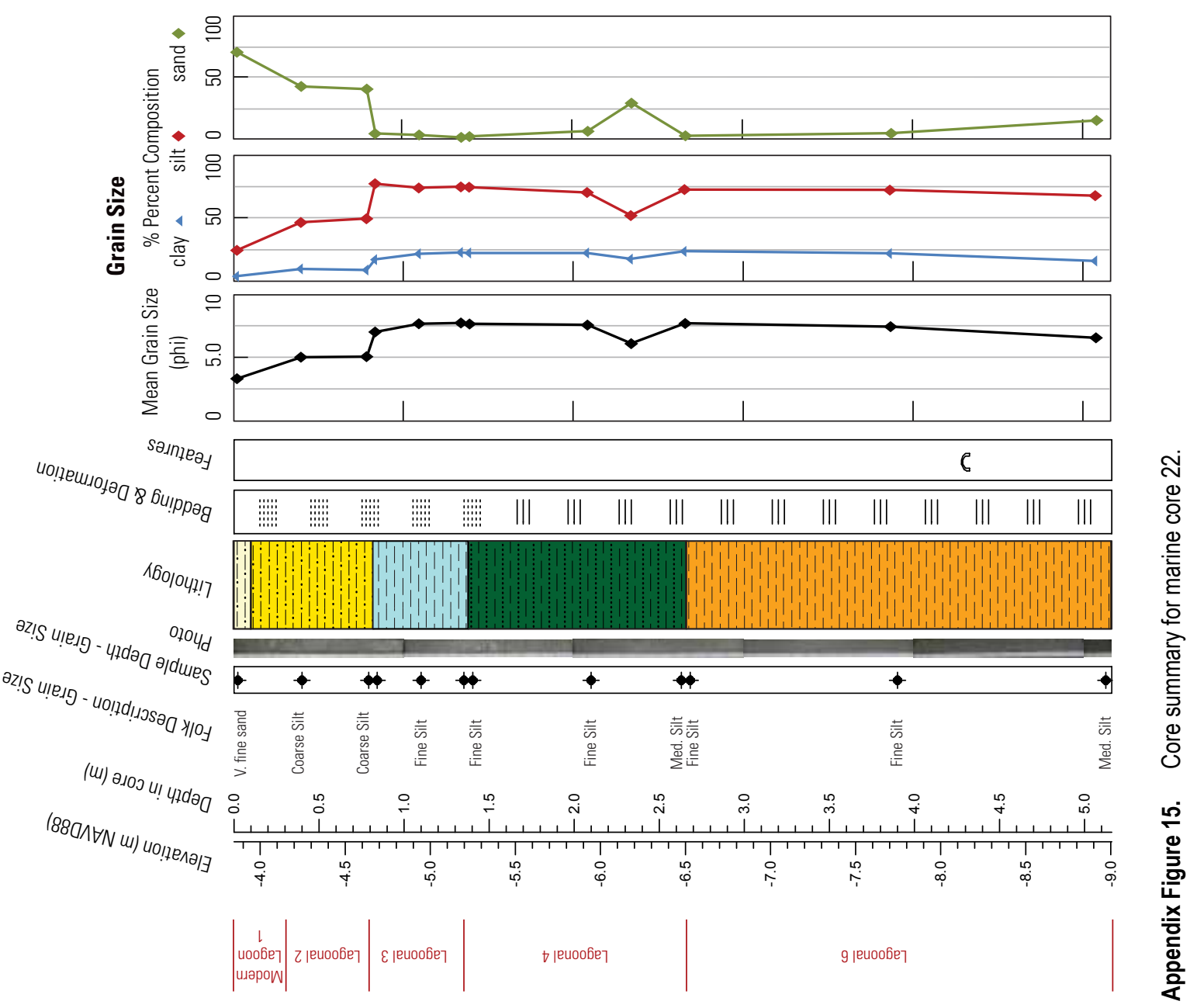



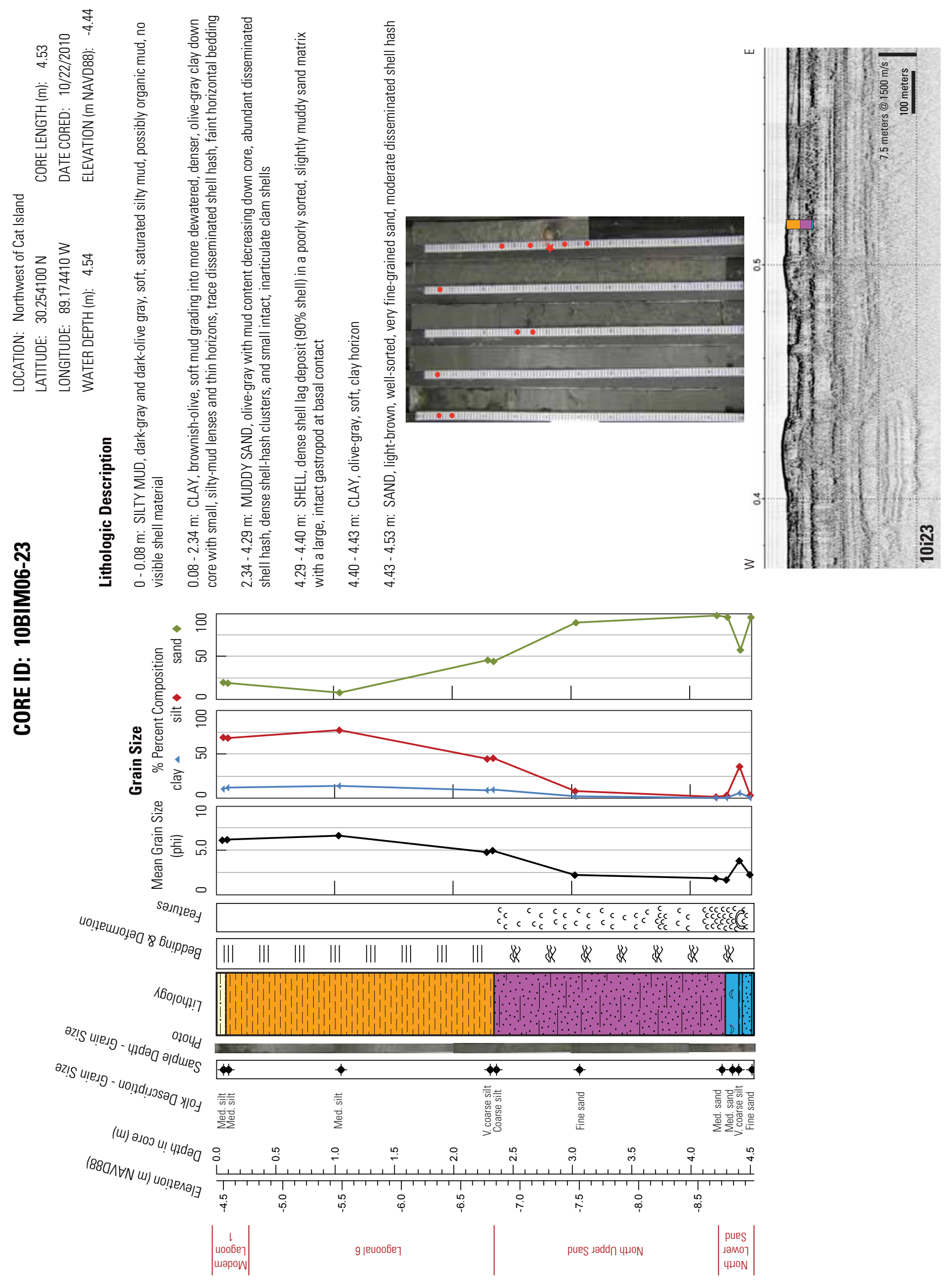

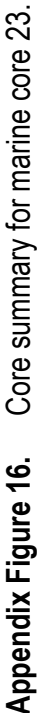



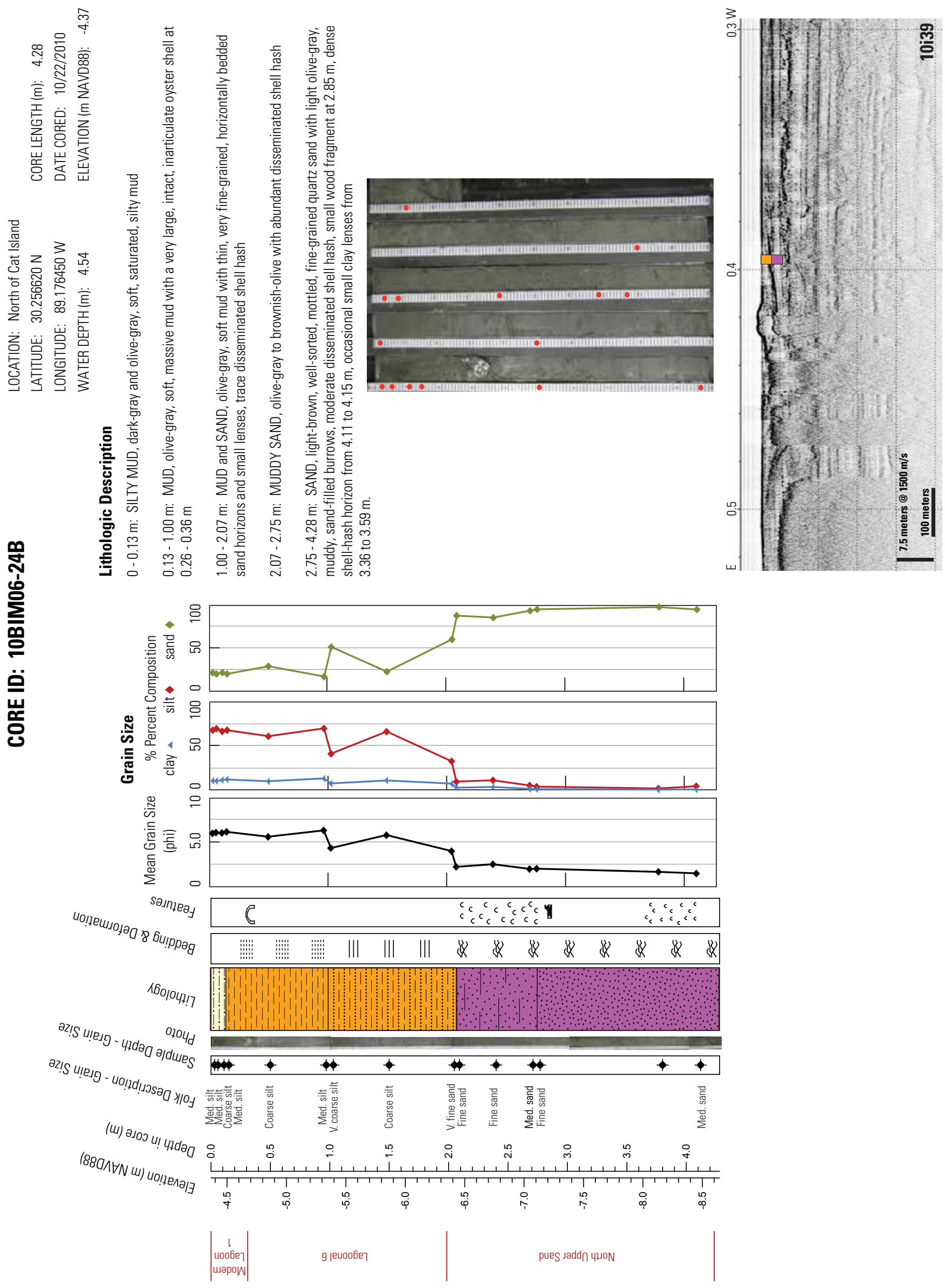


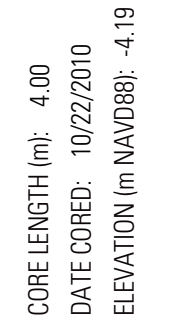

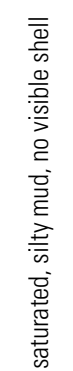

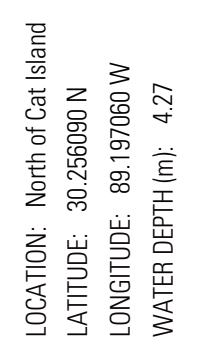

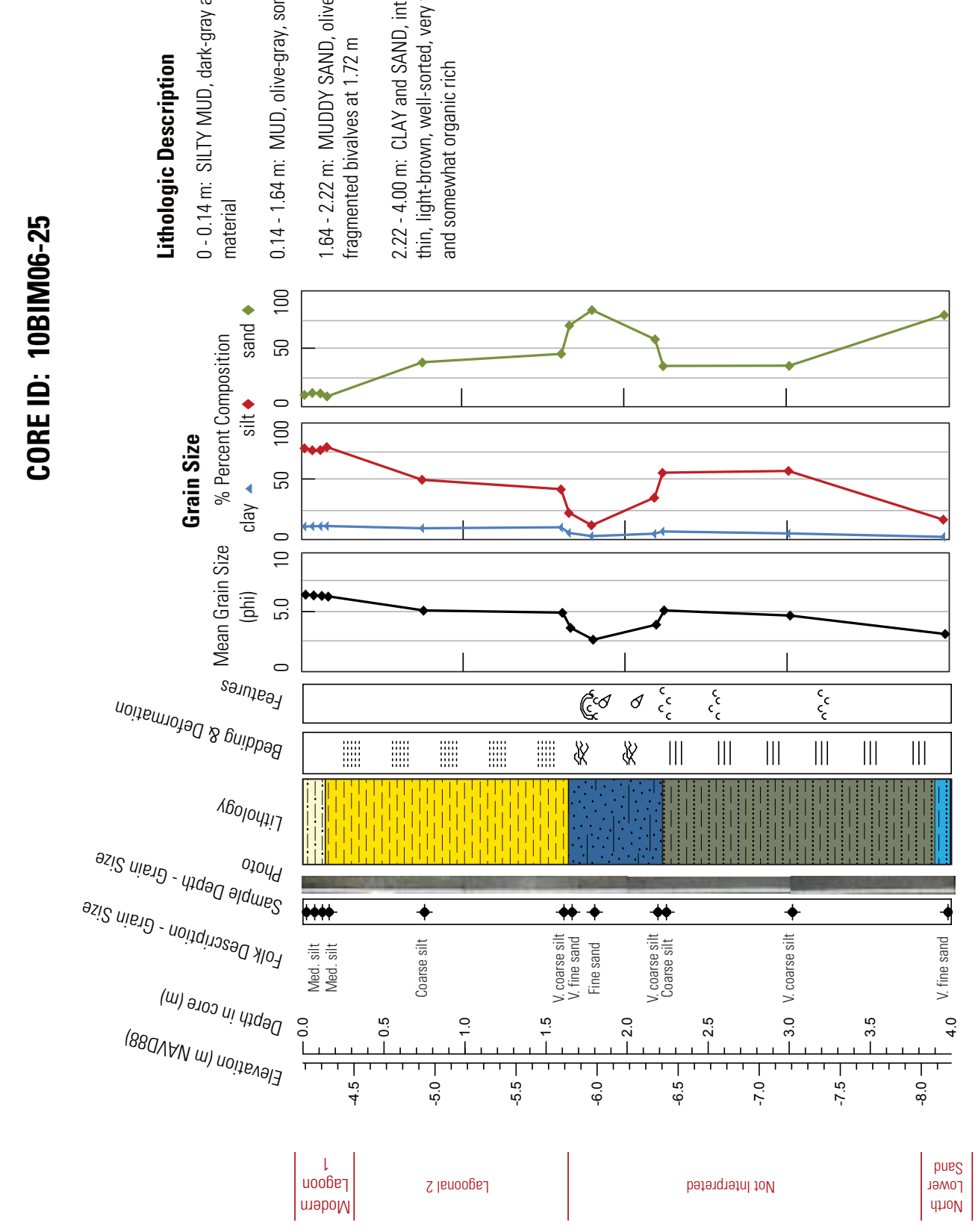
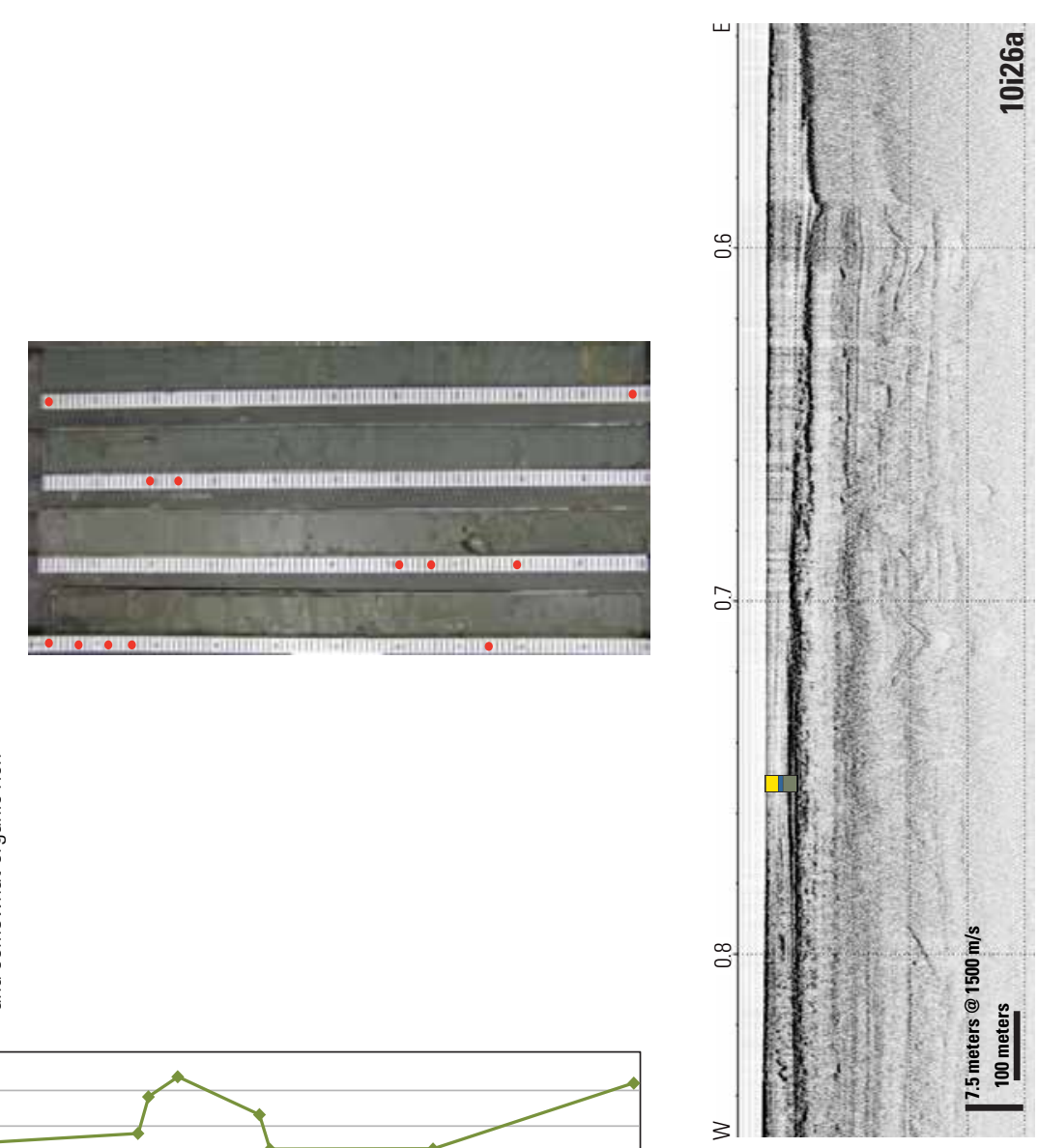

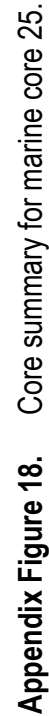




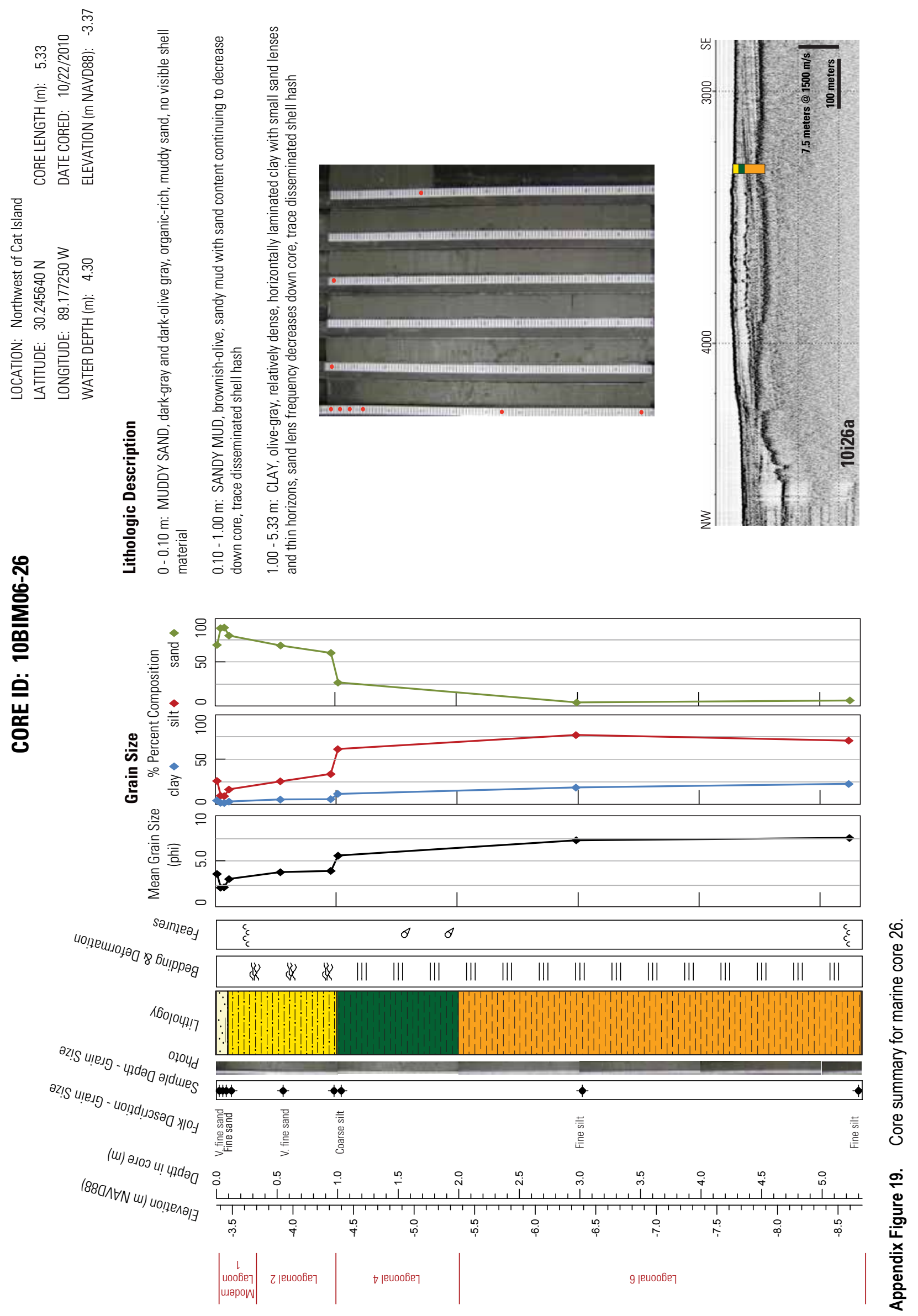




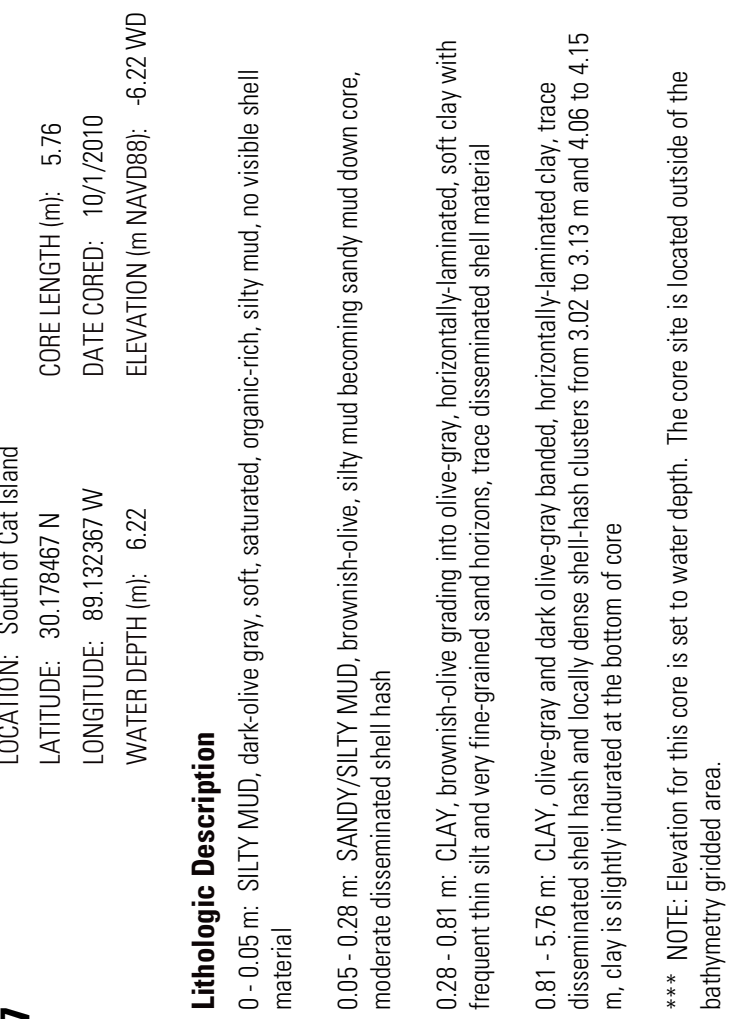
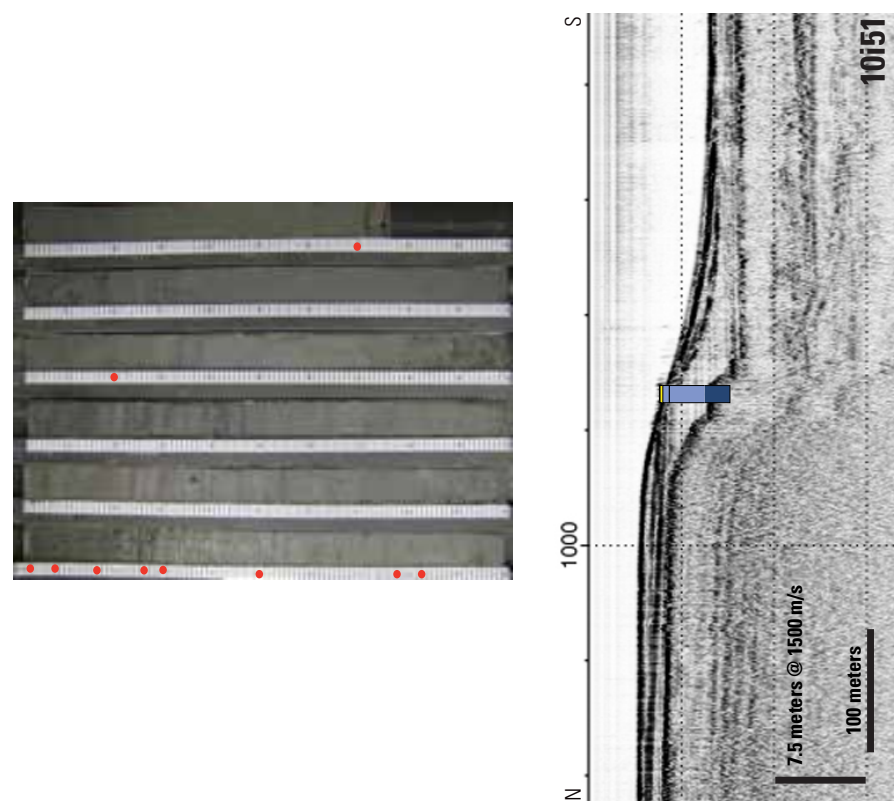

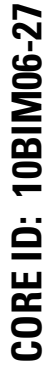
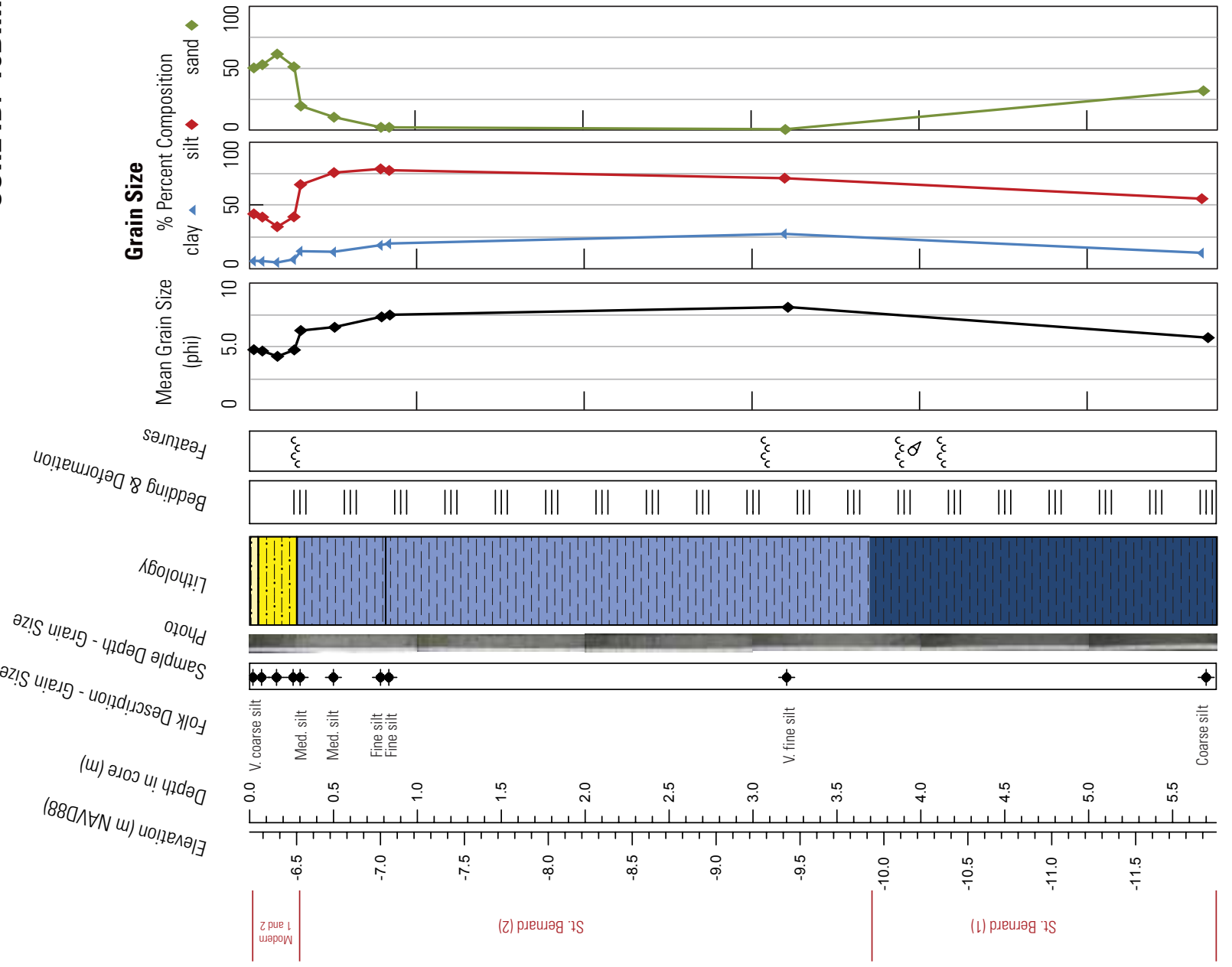

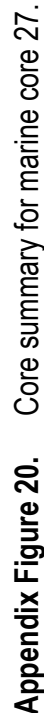


